UDK 374.7

ISSN 1512-8784

OBRAZOVANJE ODRASLIH

Časopis za obrazovanje odraslih i kulturu

ADULT EDUCATION

Journal for adult education and culture 
IZDAVAČ:

Bosanski kulturni centar Sarajevo

i

Institut za međunarodnu saradnju Njemačkog saveza

visokih narodnih škola (DVV International)

Ured u Bosni i Hercegovini

ZA IZDAVAČA:

Mr. Marijo Pejić

\section{REDAKCIJA ČASOPISA:}

prof. dr. Jelenka Voćkić-Avdagić, prof. dr. Jusuf Žiga, prof. dr. Šefika Alibabić, prof. dr. Mirjana Mavrak, prof. dr. Senada Dizdar, Emir Avdagić, M. A., Adnana Emirhafizović, dipl. psiholog

\section{POČASNI ČLANOVI REDAKCIJE:}

prof. dr. Miomir Despotović, Beograd, prof. dr. Sava Bogdanović, Zagreb, prof. dr. Radivoje Kulić, Kosovska Mitrovica

GLAVNA I ODGOVORNA UREDNICA:

prof. dr. Mirjana Mavrak

\section{LEKTOR:}

Srđan Arkoš, prof.

PRIJEVOD NA ENGLESKI I NJEMAČKI JEZIK:

Aida Fatić

\section{DTP:}

Indira Isanović

ŠTAMPA:

Forma Graf, Sarajevo

ADRESA IZDAVAČA:

Bosanski kulturni centar,

Branilaca Sarajeva 24, 71000 Sarajevo, $\mathrm{BiH}$

tel/fax: +38733 586-777

e-mail: bkc@bih.net.ba

web: www.bkc.ba

DVV International - Ured u Bosni i Hercegovini

Kulovića 8, 71000 Sarajevo, $\mathrm{BiH}$

tel: +38733 552-291; telefax: +38733 552-290

e-mail:info@dvv-international.ba

web: www.dvv-soe.org; www.dvv-international.de

Časopis izlazi uz finansijsku potporu Ministarstva za privrednu saradnju i razvoj SR Njemačke.

Časopis izlazi dva puta godišnje u tiražu od 300 primjeraka.

Rješenjem Federalnog ministarstva obrazovanja, nauke, kulture i sporta broj: 02-15-6646/01, od 29. 10. 2001. godine, časopis «Obrazovanje odraslih» je oslobođen poreza na promet i upisan je u registar medija. 


\section{Sadržaj:}

\section{ČLANCI}

Jusuf Žiga

Kako harmonizirati oficijelnu i cjeloživotnu (kontinuirano - inovativnu)

obrazovnu djelatnost?

Mirna Marković-Pavlović

Nastavak obrazovanja u uslovima neizvjesnosti - ulaznica za tržište rada,

ulaznica za biro za zapošljavanje ili dobra menadžerska startegija?

Mirza Mahmutović

Medijska konstrukcija kolektivnih sjećanja: Tretman prošlosti u polju

novinarstva, s osvrtom na postdejtonsku Bosnu i Hercegovinu

Branislava Knežić, Maja Savić

Obrazovanje u zatvoru: od prava do realizacije.

Mustafa Šuvalija

Osposobljavanje univerzitetskih nastavnika za efikasniji odgojno-obrazovni

rad kroz upotrebu kognitivno-bihevioralnih principa terapijskog rada

\section{HRONIKA, KRITIKA, POLEMIKA}

Vesna Banović

Važnost obrazovanja zasnovanog na kompetencijama i životnim vještinama

za razvoj društva 115

\section{IZ PRAKSE OBRAZOVANJA ODRASLIH}

Milica Jaramaz

Barijere participacije u obrazovanju odraslih u Crnoj Gori. 


\section{Content:}

\section{ARTICLES}

Jusuf Žiga

How to harmonise the official and lifelong learning (continual-innovative)

educational activities?

Mirna Marković-Pavlović

To continue education with doubtful prospects-ticket for the labour market, ticket for the employment agency or a good management strategy?

Mirza Mahmutović

Media-constructed collective memories: History treatment in journalism with

focus on post-Dayton Bosnia and Herzegovina

Branislava Knežić, Maja Savić

Prison education: From the right to realisation

Mustafa Šuvalija

Training of university teachers for more efficient educational work through usage of principles of cognitive behavioural therapy

\section{CHRONICLE, CRITICISM, POLEMICS}

\section{Vesna Banović}

Importance of competence - based and life skills - based education for the

development of society

\section{FROM THE PRACTICE OF ADULT EDUCATION}

\section{Milica Jaramaz}

Barriers to participation in adult education in Montenegro 


\title{
Inhalt:
}

\author{
ARTIKEL \\ Jusuf Žiga \\ Wie harmonisieren wir die offizielle und die lebenslange \\ (kontinuierlich-innovative) Bildungstätigkeit? \\ Mirna Marković-Pavlović \\ Weiterführende Bildung unter ungewissen Bedingungen - Eintrittskarte \\ für den Arbeitsmarkt, Eintrittskarte für die Arbeitsagentur oder gute \\ Management-Strategie? \\ Mirza Mahmutović \\ Medienkonstruktion von kollektiven Erinnerungen: Geschichte im Journalismus \\ mit Rückblick auf Bosnien-Herzegowina nach dem Dayton-Abkommen \\ Branislava Knežić, Maja Savić \\ Bildung im Gefängnis: vom Recht zur Durchführung \\ Mustafa Šuvalija \\ Training von UniversitätsprofessorenInnen für effizientere Erziehungs- \\ und Bildungsarbeit durch Anwendung von Grundsätzen der kognitiven \\ Verhaltenstherapie \\ .87
}

\section{CHRONIK, KRITIK, POLEMIK}

Vesna Banović

Bedeutung der auf Kompetenzen und Lebensfähigkeiten basierenden Bildung

für die Entwicklung der Gesellschaft 115

\section{AUS DER PRAXIS DER ERWACHSENENBILDUNG}

\section{Milica Jaramaz}

Hindernisse zur Teilnahme an der Erwachsenenbildung in Montenegro 131 



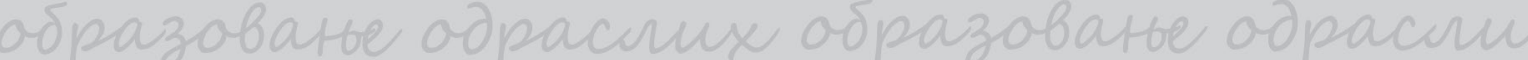
obrazovanje odraslih

adpazobatbe odpacule odpazobatbe

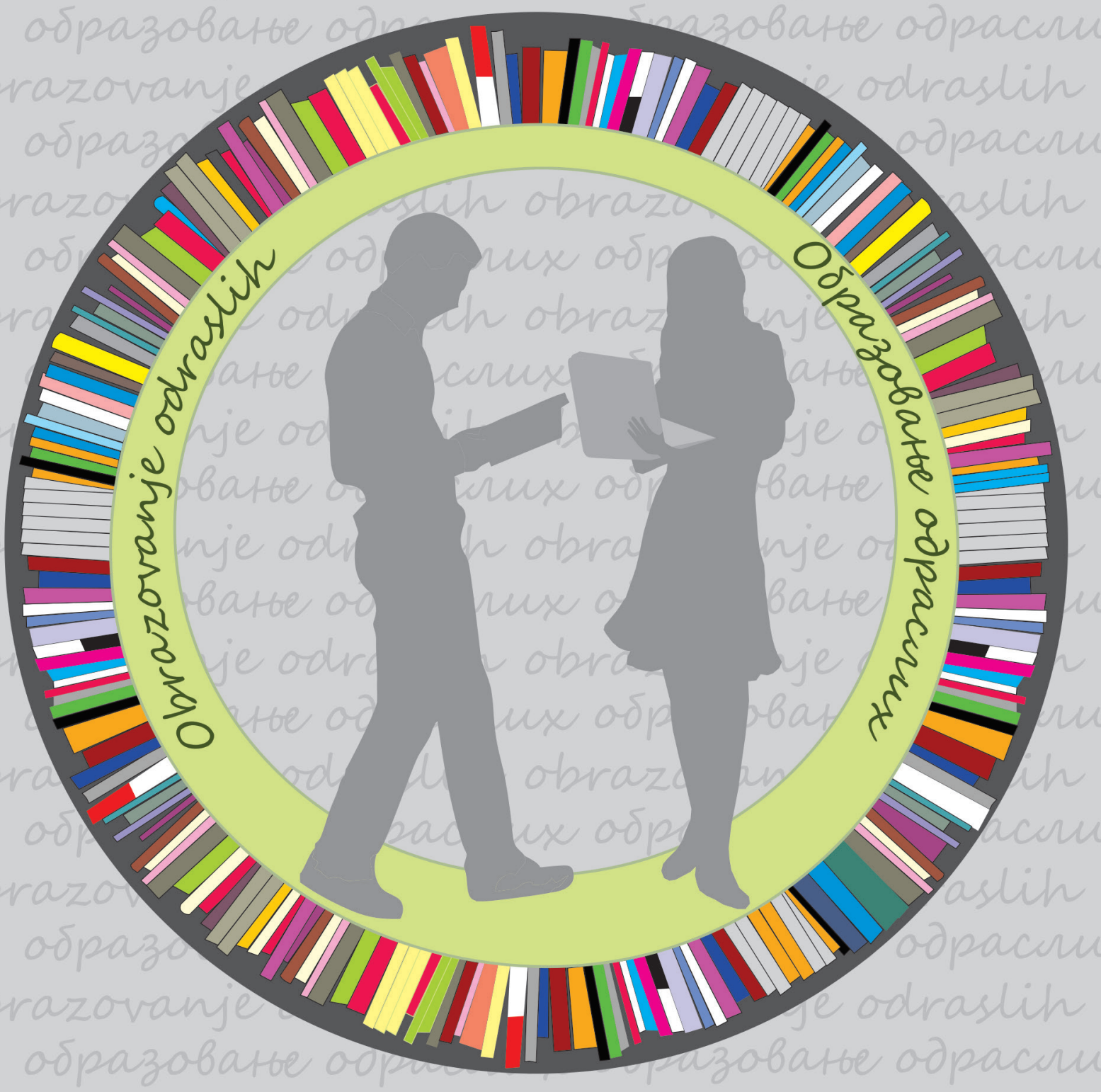

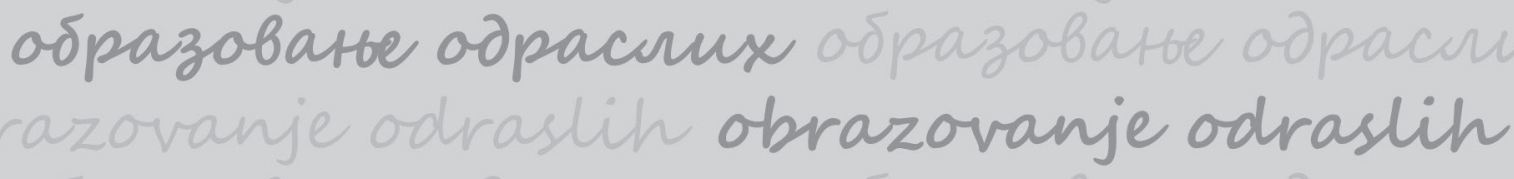





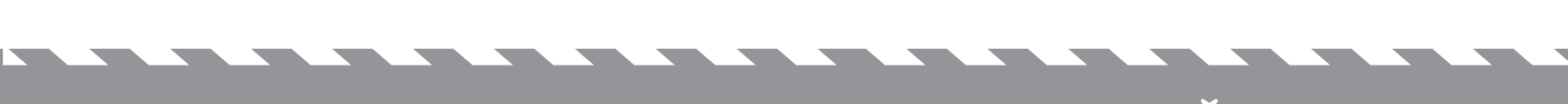
ČLANCI 

Jusuf Žigal

UDK: $371.71(497.6),, 19 / 20 ”$

\section{KAKO HARMONIZIRATI OFICIJELNU I CJELOŽIVOTNU (KONTINUIRANO-INOVATIVNU) OBRAZOVNU DJELATNOST?}

\section{- Sažetak -}

Specifičnost obrazovne djelatnosti u savremenim modernim i postmodernim društvima, ogleda se u tome što nova znanja $i$ vještine pristižu mnogo brže nego u ranijem vremenu, pri čemu ih se, uz potiskivanje dotadašnjih edukacijskih formi $i$ nastavnih programa, uključuje u obrazovne sisteme. Ali, iz toga, onda, nerijetko nastaju konfuzije, strahovi, opstrukcije, pa čak $i$ osporavanje validnosti takve, ubrzano zanavljane obrazovne djelatnosti.

Problemi se manifestiraju ne samo u odnosu prema tzv. cjeloživotnoj, neformalnoj $i$ informalnoj obrazovnoj djelatnosti nego i unutar oficijelnih edukacijskih sistema. Nameće se pitanje da li je uopće moguće harmoniziranje oficijelne, po svom karakteru uglavnom inertne, te cjeloživotne, tj. permanentno-inovirajuće obrazovne djelatnosti?

$U$ ovom radu bavimo se analizom evidentnog nerazumijevanja smisla inovirajućih edukacijskih programa i formi učenja, s jedne, te, s druge strane, značaja nauke i obrazovanja kao kvalitativnih faktora društvenog razvoja $u$ savremenom dobu, sa posebnim osvrtom na cjeloživotno učenje odraslih.

\section{Ključne riječi: formalno obrazovanje, cjeloživotno učenje, harmoniziranje obrazovne djelatnosti.}

1 Prof. dr. Jusuf Žiga, redovni profesor Univerziteta u Sarajevu, do sada objavio 25 knjiga i preko 250 drugih naučnih i stručnih radova, uglavnom iz oblasti „Sociologije”, „Sociologije BiH društva”, „Sociologije obrazovanja”, „Sociologije medicine”, Sociologije kulture” i nekih drugih znanstvenih područja, te uz ostale dužnosti, u dva mandata, obnašao funkciju prorektora Univerziteta u Sarajevu. 


\section{Uvod}

Otkako čovjek zna za sebe, uvijek je, na ovaj ili onaj način, učio i podučavao druge. Ono što se mijenjalo, bile su forme i edukacijski sadržaji. A povijesno iskustvo nas uči da je dobar samo onaj obrazovni sistem koji prepoznaje i uvažava pozitivna dostignuća u toj djelatnosti, koji je fleksibilan, te sposoban da adekvatno reagira na izazove konkretnog vremena i prostora, nipošto zatvoren, krut i nekritičan u propitivanju vlastitih i tuđih učinaka.

Specifičnost obrazovne djelatnosti u potonjem vremenu ogleda se, prije svega, u tome što nova znanja i vještine naviru daleko brže nego što se to odvijalo ranije, pri čemu ih se, uz potiskivanje dotadašnjih edukacijskih formi i sadržaja, uvrštava u obrazovni sistem. Iz toga, onda, ishode nesnalaženja, strahovi i opstrukcije, pa čak i osporavanja validnosti obrazovnih programa koji se, na tako ubrzan način, inoviraju. Valja, također, imati u vidu da je savremeni, superdinamizirani razvoj modernih i postmodernih društava, omogućen upravo tim novim znanjima i vještinama, odnosno kroz njihovu tehničko-tehnološku primjenu. A o kakvom se znanstvenom i edukacijskom dinamizmu radi, već su pokazale brojne, vrlo pretenzivno realizirane studije, $\mathrm{u}$ kojima je konstatirano da, kad je riječ o razvijenim društvima, za samo desetak godina „zastari” i bude, na ovaj ili onaj način, potisnuto više od pola onih dotadašnjih, u školama ponuđenih znanja i vještina, te zamijenjeno novim, o čemu je autor ovog teksta i ranije pisao. S druge strane nalaze se inertna društva koja su, usput kazano, nerazvijena, svakovrsno marginalizirana, u koja, nažalost, spada i bosanskohercegovačko, a gdje se cjeloživotno učenje, bilo da je riječ o njegovom formalnom, ili neformalnom modalitetu, unutar, ili, pak, izvan oficijelnih edukacijskih sistema, improvizira, pejorizira, odbacuje i tome slično. Pogotovo se to reflektira u segmentu obrazovanja odraslih.

Tematika kojom se bavimo u ovom radu daleko je složenija nego što se to, na prvi pogled, može dojmiti. Međutim, zbog prostorne ograničenosti, ovdje ćemo se fokusirati samo na neka pitanja koja su, prije svega, vezana za (ne)mogućnosti harmoniziranja oficijelne i cjeloživotne, tj. kontinuiranoinovativne obrazovne djelatnosti.

\section{Stereotipi o cjeloživotnom učenju}

Ako ostavimo postrani konfuziju oko toga šta se sve podrazumijeva pod cjeloživotnim učenjem, te korištenje nekih drugih pojmova u sinonimskom smislu („cjeloživotno obrazovanje”, „permanentno obrazovanje”, „obrazovanje odraslih" i sl.), nije naodmet podsjetiti da je njegova upotreba 
u aktualnom kontekstu inicirana prije pedesetak godina. Bila je to svojevrsna reakcija na krizu dotadašnjih obrazovnih sistema u Evropi, ali i na širem planu, kao i na ekonomsku situaciju, izazvanu uvođenjem embarga Sjedinjenim Američkim Državama i nekim evropskim zemljama od strane Organizacije arapskih zemalja izvoznica nafte, a zbog njihove podrške Izraelu u ratu na Bliskom istoku. Dakle, imalo je to širi kontekst, uključujući i novonavirući ekonomski, odnosno općedruštveni razvoj u svijetu koji se, sve više, temeljio na bitno drugačijim znanjima i tehnologijama od onih dotadašnjih, te mogućnostima njihove primjene. Preciznije govoreći, a u konkretnom, tj. razvojno opredjeljujućem smislu, cjeloživotnom učenju u Evropi se počela posvećivati posebna pažnja krajem prošlog i početkom ovog stoljeća, tj. sa usvajanjem Lisabonskog sporazuma (2000) gdje su, vrlo decidno, istaknuti ciljevi evropske ekonomije u smislu postizanja najveće razine kompetentnosti u svijetu, pri čemu se unaprijed znalo da je to nerealno bez njenog zasnivanja na novim znanjima i najrazvijenijim tehnologijama. Tada je Vijeće Evrope pozvalo Komisiju da definira „nove osnovne vještine” koje će se cjeloživotno sticati, što podrazumijeva i inovativno razvojne tehnologije, tehnološku kulturu, učenje stranih jezika, poduzetništvo i sl., pri čemu je markirano čak 13 ciljnih područja koja su trebali osmisliti stručnjaci iz država članica, zemalja EFTA/EEA, te pridruženih zemalja, kao i udrženja na evropskoj razini. Nakon toga, unutar Evropske unije, došlo je do usvajanja nacionalnih strategija vezanih za politiku cjeloživotnog učenja koje su, uvažavajući ono što im je zajedničko, po mnogo čemu, ipak, bile specifične, recimo, u slučaju Velike Britanije - preferiranje „modela zasnovanog na potražnji”, u Danskoj „modela socijalnog partnerstva”, u nekim drugim zemljama (Grčka, Portugal, Srbija...) - opredjeljenje za „centralizirani model” itd. ${ }^{2}$

To se, dakako, uz određene komparativne prednosti, reflektiralo kao otežavajuća okolnost u artikuliranju cjeloživotnog učenja kao takvog, o čemu će biti više govora u nastavku.

Iako je još u Rimskom ugovoru (1957.) naglašeno da se kroz zajedničko stručno osposobljavanje treba postići harmonični razvoj kako nacionalnih ekonomija tako i zajedničkog tržišta, umjesto snaženja „nadnacionalnih integracija” uporno se „preferirala međudržavna saradnja”, odnosno uvažavanje nacionalnih specifikuma. Primjerice, nakon što je Savjet ministara EU-a 1963. godine definirao poznatih 10 principa „za kreiranje zajedničke politike stručnog obrazovanja”, došlo je do osporavanja njihove obaveznosti

2 Vidjeti opširnije: Maksimović M., (2011) Politika doživotnog učenja u Evropi: EU, Škotska, Danska i Srbija, Obrazovanje odraslih, br. 1/2011, vol. XI, str.: 101-121. 
za države članice, a što je, na određen način, zadržano i u Mastrihtskom ugovoru iz 1992. godine (čl. 3b): ”...Zajednica će preduzimati akcije, u skladu sa principom supsidijarnosti, samo ako se ciljevi predloženih akcija ne mogu postići od strane država članica."

U artikuliranju cjeloživotnog učenja unutar Evropske unije čini se posebno važnim „Memorandum o cjeloživotnom učenju” (2000.), gdje je ono precizno definirano kao esencijalni faktor u tranziciji ekonomije i društva, ali na bazi znanja koje će se permanentno usavršavati, uključujući i vještine, te kompetenciju. To znači da je u kreiranju obrazovnih politika tek u novije vrijeme došlo do ozbiljnijeg pomjeranja ingerencije sa nacionalnog ka nadnacionalnom nivou. Tako je 2004. godine Vijeće Ministara EU usvojilo Rezoluciju o cjeloživotnoj karijernoj (profesionalnoj) orijentaciji koja obavezuje države članice „da sistemski razvijaju karijernu orijentaciju u skladu sa prihvaćenim usmjerenjima." Samo četiri godine kasnije (2008.) usvojena je i druga rezolucija koja se tiče ovog pitanja, a gdje se insistira „na boljoj integriranosti cjeloživotne karijerne orijentacije”, i to „u svim životnim dobima”, uključujući dostupnost „za sve građane”, „razvijanje kvaliteta pružanja usluga”, te ,poticanje sudjelovanja i koordinacije između različitih aktera.”, kako „na nacionalnoj, tako i na lokalnoj razini." U vezi s tim, tokom 2007. godine, formirana je „mreža politika cjeloživotnog usmjeravanja” (European lifelong guidance policy network - ELGPN), s ciljem da se pomaže članicama u realiziranju Programa cjeloživotnog učenja, a koji je proizišao iz već pomenutih, kao i nekih drugih, unutar EU usvojenih, rezolucija.

Naravno, time nije okončana aktivnost oko daljeg afirmiranjai osmišljavanja cjeloživotnog učenja u evropskom obrazovnom prostoru. Već 2010. godine Evropska komisija je usvojila inoviranu Strategiju (Evropa 2020) u kojoj je preferiran „pametan, održiv i sveobuhvatan razvoj” ovog kontinenta u narednom desetljeću, sa fokusom na kvalitativno unapređenje obrazovanja, povećanje zaposlenosti i afirmiranje tzv. zelene ekonomije, odnosno održivog razvoja i zaštite životne sredine. Apostrofirana je, također, nužnost smanjenja stope napuštanja započetog školovanja, tako da se ona svede na ispod $10 \%$, uz istovremeno povećanje obuhvata školovanjem starijih dobnih skupina (posebno od 30-34 godine) u ,tercijarnom ili ekvivalentnom nivou obrazovanja koje bi trebalo dosegnuti najmanje $40 \%$ ". Isto tako, naglašeno je da ulaganje u obrazovanje ne predstavlja nikakav društveni balast, već ga treba tretirati kao ključnu pretpostavku za prosperitetni razvoj, stvaranje novih radnih mjesta, eliminiranje siromaštva i sl., najkraće kazano, kao preduvjet za modernu ekonomiju zasnovanu na znanju. Naime, živimo u vremenu kada se 
„Znanje i inovacije smatraju motorima ekonomskog rasta i razvoja”, pri čemu se posebno insistira na informacionim i komunikacijskim tehnologijama koje omogućavaju kreiranje novih proizvoda i usluga, uključujući i digitalne. One, zapravo, postaju sve prisutnije u potonjem vremenu. Otuda je, uz ,jačanje socijalnog dijaloga”, među ciljeve pomenute Strategije uvršten ,poticaj cjeloživotnog učenja”, uključujući i , razvijanje zajedničkih instrumenata za sticanje i priznavanje kvalifikacija od osnovnog do obrazovanja odraslih" (Evropski okvir za kvalifikacije, kompetencije i zanimanja - ESCO).

I dok se, u razvijenim zemljama, trude da iznađu modalitete za anuliranje nepovjerenja i animoziteta prema cjeloživotnom učenju, pogotovo vezanog za obrazovanje odraslih, pri čemu se ne misli samo na harmoniziranje formalnih i neformalnih edukacijskih sadržaja, već i na osmišljavanje modaliteta za priznavanje diploma, certificiranja koje je rezultat doedukacija i sl., u nerazvijenim i obrazovno zapuštenim društvima se, i dalje, ovako dinamizirani obrazovni sistemi nastoje predstaviti neprihvatljivim, nekompetentnim, štetnim i tome slično.

Ovdje ćemo se podsjetiti i na ključne elemente UNESCO-ovog koncepta cjeloživotnog učenja (4 stuba), definiranog na samitu u Beču potkraj minulog stoljeća, gdje se potencira: zapošljivost; preduzetništvo; adaptabilnost; jednake mogućnosti. Evidentno je da su ovi principi, odnosno definirani ciljevi, komplementarni sa evropskim razvojnim strategijama, o kojima je prethodno bilo riječi. Oni se, u osnovi, svode na „ekonomski razvoj i konkurentnost”, te ostvarivanje „humanističko-građanskih ciljeva”, tj. prava na ravnopravnost $\mathrm{i}$ međusobno uvažavanje.

\section{Kakva je situacija u Bosni i Hercegovini?}

U svekolikoj zapuštenosti bosanskohercegovačkog društva i države očigledno je da se kaska i u implementiranju evropskog opredjeljenja vezanog za cjeloživotno učenje. Postavlja se pitanje zbog čega? Ma koliko se nekome činilo teškim, odgovor na ovo pitanje je zapravo vrlo jednostavan. ${ }^{3}$ Daleko je lakše manipulirati nepismenim ili poluobrazovanim ljudima nego školovanim osobama, ili socijalno isključenim i egzistencijalno ugroženim, od onih koji to nisu, odnosno onih koji su, u društveno statusnom i materijalnom smislu, stabilni. Ovo tim prije jer je očigledno da ovdašnji političari i dužnosnici nisu zainteresirani za sređivanje situacije u društvu, za njegov prosperitetni razvoj, a što je, opet, kako je to i prethodno naglašeno, u savremenom dobu

3 Vidjeti opširnije: Žiga, J. (2010), Zašto se zanemaruje obrazovanje odraslih u Bosni i Hercegovini, časopis „Obrazovanje odraslih”, br. 2/2010, vol. X, str. 111-118. 
nezamislivo bez odgovarajuće, kontinuirano inovativne, obrazovne djelatnosti i nauke, kao kvalitativnih razvojnih resursa.

Problem je i u ovdašnjoj percepciji cjeloživotnog učenja. Ono se, na ovom prostoru, uglavnom svodi na obrazovanje odraslih u smislu sticanja nekih elementarnih znanja i vještina, ili na određenu stručnu doedukaciju, vezanu za konkretna radna mjesta, a što se stiče kroz tzv. „večernje škole”, „kurseve” i sl., poput elementarnog osposobljavanja za rad na računarima, učenja stranih jezika, nekih zanatskih vještina (zidari, keramičari, tesari, krojači, frizeri...), potom, kroz realiziranje programa nevladinog sektora koji su vezani za promoviranje vrijednosti civilnog društva itd. Kad je riječ o kontinuiranom inoviranju oficijelnih formi učenja i nastavnih programa, kao takvih, situacija je na ovom prostoru uistinu deprimirajuća, a što je potvrđeno u više istraživanja, uključujući i ona najnovija. ${ }^{4}$

$\mathrm{S}$ jedne strane imamo evidentni animozitet i opstruiranje cjeloživotnog učenja, osporavanje njegove validnosti i sl., a, s druge strane, kada se tome i pristupi, poseže se za improvizacijom koja je, u pravilu, kontraproduktivna. U takvom kontekstu se može govoriti i o dosadašnjem iskustvu u implementiranju tzv. bolonjskog načina studiranja, koje bi, također, trebalo preferirati inovativnost, dakako vezanu za visoko obrazovanje. Umjesto nuđenja kvalitativno novih znanja i vještina, odnosno stvarnog unapređenja obrazovne djelatnosti, koja bi, kao takva, adekvatno odgovorila na potrebe i izazove modernog i postmodernog doba, uglavnom se posegnulo za „rearanžiranjem” režima studija i ,prepakiranjem” postojećeg edukacijskog sadržaja i formi rada sa 4 na $3+2$, ili, $4+1$ godinu. Nešto je drugačija situacija sa grupacijom medicinskih fakulteta (integriranost prvog i drugog stepena studija). Sve to prati frustrirajuće birokratiziranje, te razna „knjiženja” studentskih učinaka koja nemilosrdno gutaju vrijeme i energiju, naročito asistentskog osoblja, a što bi se, u neposrednijem zajedničkom radu sa studentima, moglo daleko plodotvornije iskoristiti.

Istovremeno, prisutan je problem finansiranja cjeloživotnog učenja, pri čemu se prije svega misli na budžetsku podršku u realiziranju takvih edukacijskih sadržaja. Nešto bolja situacija je u privatnom, kao i u tzv. nevladinom sektoru, gdje se obezbjeđuju ne samo sredstva za realiziranje određenih edukacijskih programa već, što je još važnije, priznaju se stečene

4 Vidjeti: Banović, V. (2013), Uticaj obrazovanja zasnovanog na kompetencijama i životnim vještinama na razvoj društva (magistarska teza, odbranjena na FPN Sarajevo); Hodžić, E. (2008), Cjeloživotno učenje u Bosni i Hercegovini, Centar za sigurnosne studije BiH, Sarajevo; Ćosić, A. (2013) Obrazovanje u Bosni i Hercegovini i postkonfliktna obnova društva (odbranjen magistarski rad na FPN Sarajevo). 
diplome, certifikati i sl., vezani za neformalne edukacijske programe, odnosno za cjeloživotno učenje.

Najkraće kazano, bosanskohercegovačko društvo ima višestruke razloge za pretenzivnije prihvatanje i promoviranje cjeloživotnog učenja, pogotovo kad je riječ o obrazovanju odraslih. Suočeni smo sa enormno velikim procentom nezaposlenih osoba (gotovo da ih ima koliko i onih zaposlenih, dakako, ako se, u vezi s tim, držimo oficijelnih pokazatelja, jer, sigurno, nije zanemarljiva cifra onih koji „rade na crno”, što je, opet, tema za sebe). S druge strane, pitanje je koliko su ranije stečena znanja i vještine nezaposlenih osoba $u$ ovom društvu ,upotrebljive” za nove tehnologije, čak i da postoji mogućnost njihovog angažmana. Osim toga, Bosna i Hercegovina je zahvaćena tranzicijskim tokovima u svim segmentima njenog društva, od politike, preko ekonomije, do obrazovanja, kulture, zdravstva.., zašta su također potrebna nova znanja i vještine. I, umjesto da bude činilac prosperitetnog razvoja društva, ovdašnji obrazovni sistem je doveden u takvu situaciju da se manifestira kao faktor koji dodatno generira krizu u ovoj zemlji. Ideološki je do te razine kontaminiran da su u njeg ugrađeni čak i elementi aparthejdske segregacije (diskriminacija djece po nacionalnoj i vjerskoj pripadnosti: „dvije škole pod istim krovom”, onemogućavanje školovanja na maternjem jeziku, pohađanje tzv. nacionalne grupe predmeta i sl.), što je krajnje pogubno za budućnost ovog društva, posebno imajući u vidu njegov multietnički, multikonfesionalni i multikulturni karakter.

Ali, vratimo se odgovoru na postavljeno pitanje koje je sadržano u naslovu ovog rada (kako harmonizirati oficijelnu i cjeloživotnu obrazovnu djelatnost?), iako su pojednostavljena sublimiranja uvijek rizična: harmoniziranje oficijelno-formalnih obrazovnih sistema i cjeloživotnog učenja ne samo da se čini mogućim, nego je to i imperativno, imajući u vidu da je superdinamizirani razvoj modernih $i$ postmodernih društava rezultat upravo kontinuiranog inoviranja znanja i vještina, te njihove tehničko-tehnološke primjene.

Radi se, zapravo, o tome da li se to želi, ili, pak, ne želi učiniti. Otuda su, u vezi s tim, prisutne određene poteškoće, animoziteti i opstrukcije, ali koje su, prije svega, mentalne, a ne neke, objektivno nepremostive naravi. Da pojasnimo. Adekvatno inoviranje nastavnih sadržaja i formi učenja, tj. njihovo kontinuirano prilagođavanje potrebama i izazovima konkretnog prostora i vremena, naprosto, ne može po sebi biti upitno. Može biti upitna pretenzivnost sa kojom se tome prilazi u smislu improviziranja, insistiranja na nečemu što je, u datom trenutku, realno govoreći, neizvodivo itd. 


\section{Zaključna razmatranja}

Cjeloživotno učenje je imperativno u savremenom dobu jer se razvoj modernih i postmodernih društava primarno temelji na kontinuirano inovativnim znanjima i vještinama, te njihovoj tehničko-tehnološkoj primjeni. Koliko god se brzo napreduje, istovremeno se, takvim tempom, i zastarijeva. Za razliku od minulih vremena, kada je to bilo odlučujuće važno, prirodno bogatstvo nekog društva tek je potencijalna, a nikako po sebi dovoljna, komparativna prednost za njegov prosperitetan razvoj. Jer, nužno je znati kako, u razvojnom smislu, iskoristiti raspoložive materijalne resurse. S druge strane, insuficijentnost prirodnih resursa moguće je ,anulirati” znanstveno stručnim potencijalima, o čemu zorno svjedoče neke najrazvijenije zemlje svijeta, poput Japana.

Stoga se u razvijenim zemljama svijeta toliko ulaže u nauku i obrazovanje, uključujući i stimuliranje cjeloživotnog učenja. Ono je, kao praksa, sve prisutnije i u oficijelnoj, a ne samo u tzv. neformalnoj obrazovnoj djelatnosti, školovanju odraslih i sl. U vezi s tim, osvrnuli smo se na aktualni aktivizam unutar Evropske unije. To nikako ne znači da ne postoje poteškoće u zaživljavanju, odnosno promoviranju potrebe cjeloživotnog učenja. One su posebno prisutne $\mathrm{u}$ harmoniziranju oficijeno-formalnih i neformalnih modaliteta učenja, oko priznavanja diploma, certificiranja i sl. Ali, evidentno je da se to sve više prevazilazi u razvijenim društvima, gdje je definitivno prevladala svijest o nužnosti cjeloživotnog učenja, uključujući i kontinuirano inoviranje nastavnih sadržaja u oficijelnim obrazovnim sistemima, a ne samo u neformalnim modalitetima permanentne doedukcije, baš kao i u pronalaženju načina za priznavanje diploma.

Međutim, u nerazvijenim društvima koja su, usput kazano, u obrazovnom smislu zapuštena, a u koja, nažalost, možemo uvrstiti i bosanskohercegovačko, još uvijek su prisutni:

- Animoziteti i opstruiranja prema cjeloživotnom učenju, govoreći općenito. Umišlja se da je za cijeli život „dovoljno” ono što se jednom u školi i na fakultetu nauči, te dobijenom diplomom „ovjeri”!;

- Želja da se po svaku cijenu sačuvaju naslijeđeni modaliteti učenja, te, koliko je to god moguće više, zadrže postojeći nastavni sadržaji (,trebam educirati” onako kako su mene educirali!);

- Obrazovanje odraslih se pejorizira u smislu „večernjih škola” i „kurseva za nepismene”, osposobljavanja poluobrazovanih osoba za određena, manje zahtjevna, „radnička zanimanja”, najčešće u građevinarstvu, šumarstvu, tekstilnoj industriji i sl.; 
- Najkraće kazano, a što je i prethodno naglašeno, harmoniziranje oficijelno-formalnih, po svom karakteru uglavnom inertnih, obrazovnih sistema i cjeloživotnog učenja je moguće pod uvjetom da se to istinski želi, a uz to je i imperativno ako uvažavamo činjenicu da je superdinamizirani razvoj modernih i postmodernih društava rezultat upravo inovativnih znanja i vještina, odnosno njihove tehničko-tehnološke primjene.

\section{HOW TO HARMONISE THE OFFICIAL AND LIFELONG LEARNING (CONTINUAL-INNOVATIVE) EDUCATIONAL ACTIVITIES?}

\section{- Abstract -}

Specificity of educational occupation in modern and post-modern societies is reflected in the fact that new knowledge and skills appear much faster nowadays, whereby they are being included into educational systems through repression of existing educational forms and programmes. But this often causes confusion, fears, obstructions and it even compromises the validity of educational activities affected by this accelerated renewal.

Problems manifest not only in attitudes towards so-called lifelong, nonformal and informal education activities, but also within official education systems. A question arises if it is even possible to harmonise the official educational practice, which is rather inert, and lifelong respectively continualinnovative educational activities?

In this paper we analyse the evident incomprehension of innovative educational programmes and learning forms and on the other hand the lack of understanding of importance of science and education as qualitative factors for the societal development in modern times with focus on lifelong learning of adults.

Keywords: Formal education, lifelong learning, harmonisation of educational activities. 


\section{Literatura:}

- Banović, V. (2013), Uticaj obrazovanja zasnovanog na kompetencijama i životnim vještinama na razvoj društva (magistarska teza, odbranjena na FPN Sarajevo).

- Ćosić, A. (2013), Obrazovanje u Bosni i Hercegovini i postkonfliktna obnova društva (odbranjen magistarski rad na FPN Sarajevo).

- Hodžić, E. (2008), Cjeloživotno učenje u Bosni i Hercegovini, Centar za sigurnosne studije BiH, Sarajevo.

- Maksimović, M. (2011), Politika doživotnog učenja u Evropi: EU, Škotska, Danska i Srbija, Obrazovanje odraslih, br. 1/2011, vol. XI, str.: 101-121.

- Žiga, J. (2010), Zašto se zanemaruje obrazovanje odraslih u Bosni i Hercegovini, časopis „Obrazovanje odraslih”, br. 2/2010, vol. X, str. 111-118. 
Mirna Marković-Pavlovićl

UDK: 159. 9:316]:331.5

\section{NASTAVAK OBRAZOVANJA U USLOVIMA NEIZVJESNOSTI - ULAZNICA ZA BIRO ZA ZAPOŠLJAVANJE ILI DOBRA MENADŽERSKA STRATEGIJA?}

\section{- Sažetak -}

Jedna od sve češće naglašavanih interpretacija bosanskohercegovačkog konteksta sugeriše kako visokoobrazovne institucije $i$ tržište rada vode dvije (neprimjereno) odvojene politike. Istovremeno, mladi ljudi vlastitim procjenama rizika i u skladu sa mogućnostima koje im stoje na raspolaganju kroz nastavak obrazovanja nastoje povećati svoje prilike na tržištu rada. Da li je ovo ulaganje (vremena, materijalnih resursa, entuzijazma) zaista svrsishodno ili barem proporcionalno vrijednosti očekivanog ishoda? Čini se da će ova hipoteza prvi put značajnije biti ispitivana kada se pojedinac suoči sa (ne)vjerovatnošću pronalaska zaposlenja u struci, a drugi put kada se suoči sa izazovom očuvanja statusa zaposlenja, jednom kada uđe na tržište rada.

Ključne riječi: nesigurnost posla, mlađi zaposlenici, obrazovni sistem, obuka i trening u radnim organizacijama.

1 Mr. Mirna Marković-Pavlović, viši asistent, Odsjek za psihologiju Filozofskog fakulteta u Sarajevu, Univerzitet u Sarajevu. 


\section{Uvod}

Mladi ljudi u visokoobrazovnim institucijama još u vrijeme kada bi svoje značajne resurse: kognitivne kapacitete i spremnost i želju za obrazovanjem trebali ulagati u krajnje logičnu svrhu - sticanje kompetencija i anticipiranje njihove konkretne primjenjivosti, to ne mogu postići u potpunosti. Ovi budući zaposlenici, valoriziraju vlastite prilike za zapošljavanje nakon završetka obrazovanja i svoje kognitivne resurse dodatno ulažu i u predviđanje mogućih ishoda. Ponekad, njihove procjene o tome bivaju u dobroj mjeri oblikovane stavovima značajnih drugih (kolega, prijatelja, roditelja) i njihovim iskustvima u pronalasku posla. Stoga i ne čudi kako ne tako optimistične poruke iz okruženja utječu na to da ovi mladi ljudi ponekad gube motivaciju za ulaganje napora u postizanje obrazovnih ciljeva. Ta povremena kriza svrsishodnosti biva uglavnom privremena. Ipak, o tome koliko je ona potencijalno ozbiljna govori činjenica da će se važnost i svrsishodnost obrazovanja i daljneg ulaganja u obuku i trening ponovo preispitivati i na radnom mjestu. Tada će se imati prilika vidjeti da li obuka i trening povećavaju prilike za očuvanje konkretnog posla i da li donose neku drugu, sekundarnu dobit, poput povećanja šanse ovih zaposlenih na tržištu rada nakon eventualnog gubitka trenutnog posla?

U vrijeme kada zaposlenje u budućnosti postaje sve neizvjesnije, a doživljaj zaposlenika o njihovoj nemoći da preveniraju nepovoljne ishode, poput neželjenog gubitka posla, sve intenzivniji, pronalazak efikasnih strategija za suočavanje sa neizvjesnošću postaje pravi izazov. Razina doživljene nesigurnosti posla i kontinuirana kognitivna evaluacija vlastitog radnog iskustva ,zauzimaju,, značajne kognitivne resurse, koji ne mogu istovremeno biti iskorišteni na nekom drugom polju. Zaposlenici su u takvim okolnostima manje fokusirani na izvršavanje radnih zadataka, a više na anticipaciju mogućeg stresnog događaja. To njihovu kognitivnu i bihevioralnu izvedbu postavlja na nižu razinu od optimalne.

U ukolnostima kada bi nosioci stvarnih društvenih promjena, mladi obrazovani ljudi, trebali s lakoćom pronalaziti prilike za opravdavanje vlastitih ulaganja, ali i ulaganja nastavnog osoblja i države u postizanje obrazovnih ciljeva, takve prilike nisu jednostavno dostupne. Može li menadžment u radnoj organizaciji u uslovima opšte neizvjesnosti prepoznati priliku da obrazovanju dâ dodatnu vrijednost ulaganjem napora da svojim zaposlenicima ponudi trening i obuku? Da li je ovo efikasna strategija mudrog rukovođenja? 


\section{Doživljaj nesigurnosti posla kao doživljaj prijetnje realizaciji brojnih funkcija koje rad ima u životu pojedinca}

Da bi se što realnije sagledale vrijednosti koje obrazovanje (obuka i trening) zaposlenih može imati u očuvanju njihove zapošljivosti i povećanju njihovog profesionalnog samopouzdanja, važno je podsjetiti na to koliko značajnu ulogu posao i radno mjesto imaju u životu pojedinca. Taj uvid bi trebao dodatno ukazati na serioznost doživljaja o postojanju mogućnosti gubitka takve vrijednosti - zaposlenja i mogućnosti za unapređenje vlastitih kompetencija.

Razumijevanje značenja ostvarenosti pojedinih aspekatačovjekovogživota, poput njegove radne uloge, predstavlja jasan put ka sagledavanju značenja i ozbiljnosti koju doživljena prijetnja njegovoj realizaciji ili kontinuitetu (npr. nesigurnost u vezi sa kontinuitetom trenutnog zaposlenja) može ostaviti na kognitivnom, konativnom kao i na ponašajnom planu pojedinca.

Pored izuzetno važne ekonomske, rad ima i vrlo važnu socijalnu i psihološku funkciju u životu čovjeka (Šverko, 1991). Rad omogućava socijalnu interakciju, uspostavljanje i razvijanje prijateljstava ili poznanstava, strukturiranje vremena, a predstavlja i izvor društvenog statusa i prestiža. Uz sve to, on predstavlja značajan dio identiteta pojedinca, izvor je njegovog samopoštovanja. Kroz rad i postignuće u radu, pojedinac formira uvjerenja o vlastitoj vrijednosti, a mnogi kroz rad uspijevaju postići ispunjenje vlastitih kreativnih potencijala. Od toga da li je i u kojoj mjeri svaka od ovih funkcija realizirana, zavisit će kvalitet radnog života nekog pojedinca. Pri tome, treba imati na umu kako će stepen realiziranosti svake od funkcija zavisiti od toga do koje mjere karakteristike posla pojedinca i njegovog radnog okruženja omogućavaju ostvarenje ovih funkcija. Sasvim je jasno kako nesigurno okruženje, okruženje koje karakterizira neizvjesnost ishoda, poput npr. radne organizacije koja loše posluje i izložena je pritisku smanjenja broja zaposlenih, kreira nepovoljne percepcije i doživljaj nesigurnosti pojedinca, a koji je istvoremeno povezan sa objektivno lošijim prognozama za postizanje kvalitetnog radnog života u budućnosti.

I dok se pitanju kvaliteta radnog života i zaposlenja danas posvećuje velika pažnja u programima važnih institucija, poput onih koje stoje u okriljima socijalne politike u Evropskoj uniji, njegov status u našoj zemlji posljednjih 20-ak godina je sasvim marginaliziran. Brojne radne organizacije se suočavaju sa pritiscima pravdanja bazne ekonomske isplativosti opstanka, a posljedično sistem vrijednosti mnogih zaposlenih u vrh postavlja sigurnost posla, jer se čini važnijim od bilo čega danas imati posao, pa ostalo tek nakon toga. No, 
ovakva situacija samo je konglomerat brojnih nepovoljnih kretanja, poput rata u $\mathrm{BiH}$ i znakovitog pada ekonomije, ali i odjeka velike ekonomske krize koja je pogodila cijeli svijet. Ratna dešavanja na teritoriji bivše Jugoslavije uništila su industrijske kapacitete, a postratni period svjedoči težak oporavak infrastukture, koja u pojedinim segmentima do ove godine nije uspjela dostići niti prijeratni nivo. S druge strane, nepovoljne promjene na globalnoj ekonomskoj sceni inicirale su nepopularne trendove o kojima je, što prije, potrebno osvijestiti i poslodavce i zaposlenike, kako bi se konstruktivnije sa njima suočavali. Stoga, zabrinutost u vezi sa budućnošću zaposlenja potrebno je staviti u jedan širi koncept nesigurnosti, koji nadmašuje granice lokalnog, kako bi se razumjela njena fenomenologija.

\section{Neusklađenost obrazovnog sistema i tržišta rada}

Postojeće stanje u BiH vezano za usklađenost između obrazovnog sistema koji proizvodi kadrove i potražnje na tržištu rada okarakterisano je nezadovoljavajućim u više analiza tržišta rada (npr. Analiza politika u oblasti povezanosti obrazovnog sistema i tržišta rada u Bosni i Hercegovini, 2011.). Nepostojanje adekvatnih mehanizama koji prosljeđuju informacije sa tržišta rada o ponudi i potražnji radne snage mehanizmima za kreiranje politike obrazovanja, prepoznaje se kao jedan od ključnih problema. Posljedice toga su ozbiljne i dugoročne, a najprije se prepoznaju u deficitarnosti određenih zanimanja(npr.zanatskihzanimanja,nekih srednjoškolskih stručnihzanimanja, poput: veterinarski tehničar ili tehničar elektronske optike, ili zanimanja sa visokom i višom spremom, kao što su: inžinjer geotehnike, diplomirani farmaceut, diplomirani grafički inžinjer) paralelno uz kontinuirano povećanje produkcije drugih zanimanja, koje zbog prekobrojnosti kadrova iz te oblasti vodi samo povećanju broja registrovanih na zavodima za zapošljavanje. Visoka stopa nezaposlenosti povezana je sa maladaptacijama na domaćem tržištu, koje se očituju i u fenomenu prekomjernog obrazovanja (engl. overeducation). Uz prekomjerno obrazovanje najčešće se pominje i fenomen nedovoljnog obrazovanja (engl. undereducation). CPU studija ${ }^{2}$ (2011) tržišta rada u $\mathrm{BiH}$ identificirala je oba ova fenomena kao vrlo čestu pojavu u $\mathrm{BiH}$. I dok se pod prekomjernim obrazovanjem podrazumijeva da nezaposlene osobe prihvataju poslove koji su ispod njihovih stečenih kvalifikacija, nedovoljno obrazovanje indicira nedostatak kadrova sa znanjima potrebnim za obavljanje određenih poslova. I u jednom i u drugom slučaju dolazi do

2 CPU- Centar za politike i upravljanje. Analiza politika u oblasti povezanosti obrazovnog sistema i tržišta rada u Bosni i Hercegovini, april, 2011. 
povećanja troškova: u prvom slučaju zbog rasipanja sredstava na obrazovanje ovih kadrova, a u drugom slučaju zbog angažovanja ili uvoza deficitarnih kadrova.

Percepcija ovakvog stanja na tržištu rada, a posebno o poželjnosti ili nepoželjnosti određenih profila zanimanja, kod zaposlenih ili onih koji će to tek postati, može voditi kreiranju anticipacija o njihovoj zapošljivosti u budućnosti. Takva anticipacija, posebno kod zaposlenih, vjerovatno će posredovati u njihovim reakcijama na eventualni doživljaj nesigurnosti posla. Naime, osobe koje svoje zanimanje prepoznaju među deficitarnim zanimanjima na tržištu rada mogu razviti pozitivniji stav prema budućnosti čak i u uslovima nedovoljne sigurnosti zaposlenja na trenutačnom poslu. Reakcije na doživljenu nesigurnost posla tada bi mogle biti mnogo umjerenije nego kod osoba koje svoje zanimanje procjenjuju manje atraktivnim na tržištu rada.

\section{Mladi i nesigurnost posla}

Ispitivanje opravdanosti pretpostavke o postojanju dobnih razlika u doživljaju nesigurnosti posla je u brojnim istraživanjima rezultiralo nalazom koji sugeriše da razlike postoje, kao i da su mlađe osobe nesigurnije u izvjesnost svoga posla u budućnosti u odnosu na starije osobe. De Bustillo i De Pedraza (2010) zaključuju kako je nalaz o većoj nesigurnosti u budućnost zaposlenja kod mlađih očekivan s obzirom na to da mladi ljudi obično imaju nesigurnija zaposlenja, više fluktuiraju s posla, a stopa njihove nezaposlenosti je viša. Nalaz o doživljaju veće nesigurnosti posla kod mlađih osoba u skladu je sa rezultatima do kojih su u svojim istraživanjima došli npr. Roskies i Louis-Guerin, 1990., kao i Sverke i sar., 2004. (prema Maslić Seršić i Trkulja, 2009). Rezultat koji sugeriše veću nesigurnost posla kod mlađih osoba može se tumačiti iz nekoliko perspektiva.

Najprije, važno je podsjetiti kako su se u posljednjih nekoliko decenija desile znakovite promjene u načinu života koji mladi ljudi vode. Tržište rada je postalo generalno nesigurnije, a obrasci i pristupi obrazovanju kao i obrasci porodica (sve veći broj nepotpunih porodica, vanbračnih porodica, samačkih domaćinstava, itd.) su se mijenjali i dalje se značajno mijenjaju. I dok su generacije ovih mladih osoba odrastale u sistemu vrijednosti, koji je njihovim roditeljima omogućavao relativno sigurno zaposlenje, skoro pa zagarantovano samim ulaskom u neku radnu organizaciju (MacDonald, 1999), danas se mladi suočavaju sa sasvim novim uslovima i politikama zapošljavanja, koje u najmanju ruku odražavaju generalnu nesigurnost i neizvjesnost. 
Sliku svog položaja na tržištu rada, determiniranu objektivnim okolnostima povezanim sa globalnim kretanjima na tržištu rada (npr. svjetska ekonomska kriza) dodatno usložnjava specifični ekonomsko-politički kontekst našeg geografskog područja. Opažena visoka stopa nezaposlenosti u $\mathrm{BiH}$, koja se dobrim dijelom oslikava i kroz nezaposlenost mladih osoba, posebno bi mogla doprinijeti razvoju osjećaja nesigurnosti među mladim zaposlenicima. I pored samopouzdanja proizašlog iz posjedovanja savremenih saznanja iz određenih relevantnih oblasti kao i kompetencija stečenih uglavnom tokom obrazovanja (koje bi trebale doprinijeti razvoju osjećaja kompetentnosti kod mladih ljudi), nedostatak prakse tokom obrazovanja, relativno malo radno iskustvo ili nepostojanje radnog iskustva mogli bi mlade osobe staviti u nepovoljniji položaj u odnosu na starije, uglavnom iskusnije kolege. Pokazatelji analize trendova na tržištu rada kod nas (npr. Funkcionalni pregled tržišta rada u $\mathrm{BiH}$, EU CARDs, 2005, prema CPU, 2011), ali i u svijetu (MacDonald, 1999) upućuju na zaključak o tome da se mladi ljudi duže zadržavaju u obrazovanju, što vodi prevelikoj produkciji osoba sa visokoškolskim obrazovanjem. Percepcija ovakvih trendova od strane mladih ljudi može voditi stvaranju dojma o postojanju velike konkurencije među mladim zaposlenicima, a koja se prepoznaje kao potencijalni ugrožavatelj njihove prilike za zadržavanje trenutnog posla ili pronalaska novog u slučaju da izgube trenutno zaposlenje. Ovakve evaluacije dodatno mogu opteretiti predvidivost statusa na tržištu rada i razvijati osjećaj nesigurnosti posla. Autori ističu da mlade osobe pokazuju nesigurnost $\mathrm{u}$ intervjuima za posao, stoga bi njihova nesigurnost mogla biti povezana sa anticipacijom lošeg uspjeha u traženju novog posla, nakon što bi ostali bez trenutnog posla. Čini se da intervju za posao predstavlja onaj aspekt procesa traženja posla zbog kojeg mlade osobe osjećaju najveću neprijatnost. Nasuprot njima, starije kolege imaju duže radno iskustvo (imajući u vidu godine starosti), te s obzirom na to bolje pretpostavke za razvoj samopouzdanja kroz iskustvo komunikacije sa drugim ljudima u radnom procesu, a koje bi moglo doći do izražaja pri traženju novog posla. Kuhnert i Vance (1992, prema Cheng i Chan, 2008) ističu kako se razlike u rekacijama na doživljenu nesigurnost posla između mlađih i starijih zaposlenika mogu pripisati razlikama u njihovim stavovima prema poslu. De Witte (1999, prema Cheng i Chan, 2008) sugeriše u svojim analizama kako stariji zaposlenici gubitak posla mogu doživjeti tek kao prijevremeno penzionisanje, te stoga mogu doživjeti manje ozbiljnom nesigurnost posla nego mlađe osobe. Na sličan način bismo mogli pretpostaviti kako će upravo zbog razlika u stavovima prema poslu i anticipacije posljedica nastalih usljed 
eventualnog gubitka zaposlenja mlađi zaposlenici prije svoj posao doživjeti nesigurnim nego stariji zaposlenici, a nakon toga razviti i snažnije reakcije na tako doživljenu neizvjesnost svoga zaposlenja u budućnosti.

Razloge za veću opaženu nesigurnost posla među mlađim zaposlenim osobama možemo tražiti i u specifičnostima razvojnog perioda koji prate određeni razvojni zadaci, socijalna i emocionalna iskustva. Iako se mlađa odrasla dob uvriježeno percipira kao vrijeme ispunjeno različitim mogućnostima i prilikom za avanturističko preispitivanje života, mladi ljudi koji su već kročili na tržište rada napuštaju neke ranije obrasce ponašanja i preuzimaju nove uloge i obaveze. Prema teoriji razvoja odraslih Daniela Levinsona (1978, prema Schaie i Willis, 2001), ,početnički stadij,, rane odrasle dobi obilježen je sa četiri glavna zadatka, od kojih se tri odnose na karijeru osobe: izbor zanimanja, oblikovanje „Sna,, i nalaženje mentora. San predstavlja viziju života koju mlada osoba ima, a što uključuje i obrasce porodičnog života i životne okoline, ali za većinu ljudi središnja slika tog „Sna, jeste slika zanimanja. Preispitivanje napravljenog izbora zanimanja, kao i suočavaje sa posljedicama tog izbora nastavlja se i nakon stupanja na tržište rada i prvih radnih iskustava. Pod pretpostavkom da je odabrao željeno zanimanje i posao mladi čovjek se suočava sa problemima ,rane profesionalne socijalizacije,, koja se odnosi na kreiranje očekivanja u odnosu na posao koji se obavlja, pitanja slaganja sa saradnicima na poslu, od kojih se neki ponašaju i neprijateljski i suparnički, postavljanja prema autoritetu, zaštite vlastitih interesa i sl. (Schaie i Willis, 2001). Nejasnoća u radnoj situaciji koja proizlazi iz ovakvih dilema kod mladih ljudi bi posebno mogla utjecati na manjak pouzdanja u strukturiranost i predvidivost radne situacije, vlastiti status u radnoj organizaciji, a time i razvoj osjećaja nesigurnosti posla.

U prilog činjenici da mlađa odrasla dob predstavlja emotivno bremenit period života koji zbog specifičnosti ovog razdoblja može voditi pojačanom doživljaju nesigurnosti posla govori i Robinson (2011). Autor ističe kako ovaj period života, koji naziva ,krizom četvrtine životne dobi,, (engl.,,quarterlife crisis,,), obilježava borba s anksioznošću povezanom sa nesigurnošću posla, nezaposlenošću, dugovima, partnerskim ili prijateljskim vezama, a obuhvata dvadesete i tridesete godine života. U jednom istraživanju koje je proveo Robinson (2011), 86\% od ukupno 1100 mladih ljudi izvještavalo je o tome da osjećaju kako se nalaze pod pritiskom da budu uspješni u svojim vezama, finansijama i poslovima prije 30. godine života. Robinsonova relativno nova koncepcija krize četvrtine životne dobi svoje temelje ima u poznatim koncepcijama razvojnih kriza Erika Eriksona (1968, prema Robinson, 2011) i Danijela Levinsona (1978. ili 1985, prema Robinson, 2011). Pridavanje 
značaja postojanju pritiska koji mladi osjećaju zbog očekivanja koja okolina postavlja pred njih, Robinsonovu krizu četvrtine životne dobi čini također bliskom teoriji socijalnog sata, koju je predložila Neugarten (1977, prema Bertrand i Lachman, 2003). Ona je pretpostavila da će se razvoj tokom života odvijati na vrijeme ili prerano odnosno prekasno u odnosu na kulturološke norme (npr. kulturološka očekivanja u odnosu na vrijeme stupanja u brak, zapošljavanja, obezbjeđivanje stabilnih i kontinuiranih prihoda, rođenja prvog djeteta itd.). Rezultati istraživanja koja su proveli Helson i sar. (Helson i sar., 1984; Helson i Moane, 1987; Helson i Wink, 1992; Mitchell i Helson, 1990, prema Bertrand i Lachman, 2003) ilustriraju kako socijalni sat služi kao barometar u odnosu na koji pojedinac evaluira svoj uspjeh u životu. Sa pravovremenim izvršenjem obaveza i preuzimanjem uloga, pojedinac priskrbljuje socijalno odobravanje i razvija pozitivna osjećanja proistekla iz doživljaja usklađenosti vlastitih životnih iskustava sa očekivanjima koja društvo stavlja pred njega/nju. U suprotnom, osoba ostaje bez socijalne podrške, a doživljaj nekongruentnosti između društvenih očekivanja i ličnog iskustva doprinosi tome da događaji poput stupanja u brak, zapošljavanja i sl. postaju mnogo stresniji za pojedinca. U kontekstu ove teorije, socijalni sat „otkucava,, kao i vrijeme potrebno za pronalazak zaposlenja i obezbjeđivanje relativno stabilnih prihoda, stavljajući pred mlade ljude vrlo težak zadatak: pronaći i zadržati stabilan, siguran posao. Doživljaj o postojanju sveprisutnog pritiska, osjećánja razočarenja, usamljenosti, pa čak i depresije i opšte nesigurnosti, koji se najčešće vežu uz ovaj period života, mogli bi biti itekako odgovorni za razvoj osjećaja veće nesigurnosti posla kod mlađih osoba, s obzirom na specifičnosti ovog razvojnog perioda.

\section{Odgovornost za izvjesnost u zapošljavanju i zapošljivost mladih na tržištu rada}

Borba protiv nezaposlenosti i nezapošljivosti trebalo bi da se vodi još za vrijeme formalnog obrazovanja.

Dva su ključna problema koja se često stavljaju u fokus rasprava o nepovoljnim okolnostima zbog kojih mladi ne uspijevaju na tržištu rada biti ono što su prvobitno zamislili, ili ono što su njihovi potencijali, aktualizirani u konkretnom radnom kontekstu, mogli ponuditi svijetu rada.

To su:

- Neusklađenost obrazovnog sistema i tržišta rada,

- Nedovoljna usmjerenost obrazovnog sistema na sticanje kompetencija važnih za tržište rada. 
No ovo nisu jedini razlozi nepovoljne situacije na tržištu rada. Odgovornost se za ovakve nepovoljne okolnosti nesigurnosti nekada neopravdano dijeli samo između ova dva argumenta. Pitanje je: šta je sa individualnom odgovornosti pojedinca koji traži svoju ulaznicu za tržište rada? Gdje je u svemu tome odgovornost poslodavaca u kreiranju povoljnog okruženja za učenje na radu?

Još uvijek traje, i sve su prilike da će se još neko vrijeme osjećati, polemika oko toga ko se treba držati odgovornim za to što mladi ljudi nakon izlaska iz obrazovnih instituacija nemaju ključne kompetencije za obavljanje posla. Kao i mnoga druga pitanja, i ovo nudi barem dvije istine koje se međusobno ne isključuju već nadopunjavaju. Okosnica ove rasprave jeste pitanje odgovornosti. Da li je odgovoran obrazovni sistem? Da li su odgovorne strukture vlasti koje kroje upisnu politiku u obrazovnim institucijama? Da li odgovornost pripada pojedincu? Ovo pitanje je već dobilo nagovještaj svoga odgovora u prethodno istaknutom problemu ponekad vrlo naglašene disfunkcionalne komunikacije obrazovnog sistema/politika i tržišta rada. No, koliko je obrazovni sistem, gledajući u širem kontekstu zaista odgovoran?

Jedna od istaknutih uloga obrazovanja jeste osposobljavanje čovjeka za samostalan i produktivan rad koji u svojoj konačnici treba ispunjavati više značajnih psiholoških funkcija. Očekivanja mladih ljudi da će u obrazovnim institucijama dobiti sva znanja i razviti sve vještine koje će moći uspješno primijeniti na svom radnom mjestu su pogrešna pretpostavka na kojoj se, nažalost, bazira neosnovan optimizam mladog i neiskusnog pojedinca. A upravo će iskustvo posvjedočiti tome da je obrazovanje temelj za sticanje navike usmjerenog $\mathrm{i}$ kompetentnog načina razmišljanja koje će nas voditi kroz procese profesionalnog sazrijevanja. Na tom putu, znanja i vještine stečeni tokom formalnog obrazovanja predstavljaju značajnog partnera u procesu sticanja kompetencija za rad. Oni su tek poligon na kojem će se utiskivati radna iskustva, koja se, kao što i sama riječ kaže, stiču samo i jedino radom.

\section{Uloga poslodavaca u smanjenju nesigurnosti posla}

Osigurati produktivno radno okruženje sa stalno potvrđujućom spremnošću za kontinuirano prilagođavanje izazovima na lokalnom i globalnom tržištu veliki je zadatak voditelja radnih grupa i organizacija. Sinhronizacija pulsa organizacije koja živi (preživljava) sa adrenalinskim šokovima što u vidu novih tehnoloških, kompetencijskih i finansijskih izazova prispijevaju sa globalog tržišta, ponekad je veoma teška i neizvjesna. Da li će ,pacijent, preživjeti, pokazuje se, zavisit će pored ostalog i od privrženosti zaposlenika 
koji tu rade. Njihova spremnost da i u uslovima koji nisu optimalni (nerijetko suboptimalni) ulažu napor u postizanje dobrih radnih rezultata $\mathrm{i}$ poslovne izvrsnosti odredit će, dugoročno gledajući, put radne organizacije: preživljavanje ili postepeni pad u nepovrat.

Sasvim je jasno kako nesigurnost posla i neizvjesno radno okruženje predstavljaju bolnu prepreku na putu realizacije ove privrženosti. Zaposlenik koji ima sliku u kojoj poslodavac ne može ili neće (u nekom momentu razlikovanje ove dvije kategorije postaje irelevantno) obezbijediti izvjesnost zaposlenja u budućnosti, spreman je takvu situaciju procijeniti ugrožavajućom. Percepcija ugroženosti i, nerijetko, nekontrolabilnosti ishoda vodi pogoršanju stavova prema poslu i najčešće smanjenju radne učinkovitosti. Ovakvi nalazi jasno potcrtavaju zbog čega bi brigom o tome koliko se njihovi zaposlenici osjećaju nesigurno trebali biti bremeniti radni sastanci menadžementa organizacije, a strategijama suočavanja sa nesigurnošću zaposlenja strateški planovi razvoja. Tamo gdje je još uvijek uvriježeno uvjerenje da je priča o stavovima zaposlenika prema poslu, njihovoj privrženosti radnoj organizaciji tek puko opravdanje za postojanje HR-odjela ${ }^{3}$ potrebno je sprovesti logičnu persuaziju. Ubjeđivanje u suprotno od tog mišljenja ili persuazivno djelovanje s ciljem osvještavanja o značaju ljudskih resursa i njihovih osjećaja ponekad može biti vrlo jednostavno: predočiti razlike u tome kakve posljedice na rad može imati siguran a kakve nesiguran zaposlenik u svom radnom okruženju.

Privrženi zaposlenik spreman je drugima pozitivno govoriti o svojoj organizaciji, on želi ostati u njoj i spreman je uložiti velik napor u postizanju njenih poslovnih ciljeva. Percipirana nesigurnost posla može imati značajan negativan efekat na prethodno pomenuta ponašanja. Zaposlenik će u ovakvim okolnostima pokušati naći novi posao, širiti negativnu sliku o organizaciji i smanjiti ulaganje napora u radu. Nespremnost da prihvati ovakvo radno okruženje posljedično može dovesi i do (ne)kritičkog promišljanja odluka koje donosi menadžment organizacije. To će se najprije ogledati u osjećaju naglašenog negativizma spram donesenih odluka, osjećaju nepovjerenja u iskrenost u komunikaciji i želje menadžmenta da se aktivno pozabavi stanjem i pronađe najbolje strategije suočavanja sa nastalom situacijom. Sve ovo vodi bazičnom nepovjerenju zaposlenih i smanjenju njihove privrženosti.

No, ukoliko menadžment radne organizacije ne pravi ovakve pogreške i istinski želi pronaći puteve ka aktivnom suočavanju sa problemom

3 HR - engl. Human Resource - ljudski resursi; HR-odjeli: u strukturi radnih organizacija to su odjeli koji se bave upravljanjem ljudskim resursima te radne organizacije (kroz, npr., upravljanje radnim učinkom zaposlenih, ispitivanje obrazovnih potreba i realizaciju obuke i treninga zaposlenih, osmišljavanje strategija motiviranja zaposlenih za rad, itd.). 
nesigurnosti radnog okruženja nameće se pitanje: Postoji li nada za to da u radnim organizacijama i uslovima finansijske nemoći postoje načini motiviranja zaposlenika da ostanu na svojim radnim mjestima i kvalitetno rade?

Za one rukovodne stukture koje to zaista žele znati i postići, važna je spoznaja kako postoje finansijski neopterećujući načini osiguravanja privrženosti zaposlenika u uslovima nesigurnosti. Jedan od ključnih jeste osiguranje proaktivne komunikacije koja sprečava širenje glasina i omogućava pravovremenost u plasiranju važnih informacija zaposlenicima, kako dobrih tako loših. Vrlo je važno da menadžment održava imidž dostupnosti, i u skladu sa svojim primarnim radnim odgovornostima ali i razinama u organizacijskoj hijerarhiji odgovara na dileme i zabrinutost zaposlenika u vezi sa značajnim pitanjima. Usklađenost u govoru i djelovanju i konzistentnost u sprovedbi donesenih odluka stvorit će osjećaj da je situacija pod kontrolom i da se mogu očekivati pozitivne promjene. No, aktivno suočavanje menadžementa sa neizvjesnošću i nesigurnosti radnih mjesta ogleda se i u nastojanju da se kod zaposlenih razvija osjećaj osnaženosti da se vlastitim kapacitetima nose sa nesigurnošću. Tu pitanje obrazovanja na radnom mestu i sticanje kompetencija posebno ima smisla.

\section{Obrazovanje i obučavanje u radnim organizacijama}

Organizacije, koje su shvatile da bez kontinuiranog i planskog razvoja ljudskih potencijala neće biti moguće odgovoriti na promjenjive zahtjeve na tržištu rada, obrazovanje i obuku zaposlenih uklopili su u funkciju upravljanja ljudskim resursima. Ona se uglavnom odvija unutar organizacije, ali i izvan nje. Neke od njih rješenja za svoje obrazovne potrebe pronalaze i u organizaciji internih škola ili profitnih centara, odnosno preduzeća. Njihova se funkcija ogleda u obezbjeđivanju potrebnih znanja i vještina za zaposlene u samoj organizaciji ili izvan nje (Vujić, 2003). Ove organizacije su donijele odluku da će na sve promjenjivije i manje predvidive zahtjeve tržišta odgovarati na jedino mogući način: adaptivno - manifestirajući svoju fleksibilnost i prilagodljivost kako u rukovođenju i upravljanju tako i u kontekstu obezbjeđivanja uslova za sticanje kompetencija (zaposlenika) potrebnih za opstanak u punom smislu te riječi. Opstanak u ovom kontekstu posebno naglašava činjenicu da obrazovanje i obuka trebaju obezbijediti prevazilaženje tzv. „skill-gapa,, - diskrepancije između kompetencija koje zaposlenici imaju i upošljavaju u radu i onih kojima bi trebalo da teže, koje su im potrebne kako bi uspješno odgovorili na nove zahtjeve posla. 
Odlučiti da su obrazovanje i obuka dobra strategija za postizanje poslovne izvrsnosti i obezbjeđivanje poslovnih rezultata nije jedina odluka koju treba donijeti. Rukovodstvo organizacije mora strateški razmišljati, a to, između ostalog, znači prepoznati potrebe zaposlenika za određenom vrstom obrazovanja i obučavanja, a zatim napraviti plan obrazovanja i obučavanja. To između ostalog znači analizirati potrebe zaposlenika za vrstom obrazovanja i obuke, ocijeniti koje su kompetencije i na kojim poslovima (radnim mjestima) ključne za postizanje željenih rezultata, identificirati polaznike, predavače itd.

No, zabrinutost koja često proizlazi iz planiranja i prakse obrazovanja zaposlenih mogla bi biti kamen spoticanja u provedbi plana obrazovanja zaposlenih u funkciji povećanja njihove zapošljivosti. I ona je, na prvu, skoro pa dobrim dijelom opravdana. Zapravo, poslodavci se nerijetko suočavaju sa vrlo nezgodnom praksom u kojoj se prvobitna ulaganja u ljudski potencijal pokažu kao trošak. To se dešava u situacijama kada se ulažu sredstva u obuku zaposlenika za osposobljavanje za rad nakon čega neki zaposlenici odluče napustiti radnu organizaciju i potražiti novo radno mjesto i novog poslodavca. Odluku o napuštanju radne organizacije zaposlenici temelje na potrebi i želji da pronađu za sebe adekvatnije radno okruženje (ponekad je to ono koje omogućava bolje prihode, beneficije zaposlenicima, rad na savremenijim tehnologijama, manje stresno radno okruženje itd.). Pri tome, oni osjećaju veće profesionalno samopouzdanje, koje duguju svom prethodnom poslodavcu. Neki poslodavci nastoje sačuvati svoj kadar obavezujući ga da ostane u organizaciji određeno vrijeme (npr. tri godine) nakon što su prošli određenu edukaciji na trošak organizacije. Tamo gdje to nije praksa, problemi sa isplativošću ulaganja ovog tipa mogu biti prilično problematični.

\section{Uloga psihologa u obrazovanju i obuci zaposlenih}

Prenošenje stručnog znanja neophodog za rad, uvježbavanje motoričkih radnji za efikasno obavljanje posla koje treba biti brzo, tačno i sigurno predstavljalo je nekada okosnicu obučavanja i obrazovanja zaposlenih (Vujić, 2003). To se i dalje pokazuje kao vrlo važno, ali novi zahtjevi pred obukom i obrazovanjem su daleko veći. Danas se izuzetno vodi računa da obrazovanje u radnoj organizaciji ne bude pretjerano generalno, ciljno neizdiferencirano i samo sebi svrha. U takvom nastojanju, između ostalog, posebno je prepoznatljiva uloga psihologa.

$\mathrm{Na}$ putu postizanja ekonomske efikasnosti i kvalitetnog rada, uloga psihologa je značajna. Danas kada cilj obrazovanja i obučavanja seže mnogo dalje od osposobljavanja zaposlenih za rad i usvajanja vještina, psiholozi 
nose dio odgovornosti za obezbjeđivanje konteksta u kojem će zaposleni biti sve više osposobljeni da razmišljaju, rješavaju probleme u skladu sa ciljevima organizacije. Njihovo radno ponašanje treba odražavati saradljivost, spremost za prihvatanje odgovornosti, toleranciju na stres. Imajući to u vidu, psiholozi u radnim organizacijama, u saradnji sa drugim andragoškim djelatnicama unutar i izvan organizacije, nastoje dio svoje radne prakse posvetiti obuci zaposlenih iz oblasti: socijalne percepcije, komunikacije u radnim organizacijama, konstruktivnog rješavanja konflikta, timskog rada, upravljanja stresom i stilova rukovođenja, motivacije itd. Rezultati analiza zadovoljstva polaznika ovakvim treninzima sugerišu da su zaposlenicima potrebne i ove kompetencije koje izlaze izvan okvira stručnih kompetencija vezanih za radno mjesto. One ih čine samopouzdanijim u ulogama koje imaju na poslu, a nerijetko se odražavaju i na cjelokupnu dobrobit pojedinca koja se reflektira i na privatnu sferu života.

Pored ostalih, značajna uloga psihologa se prepoznaje i u savjetovanju zaposlenika pri zapošljavanju, uvođenju u posao (to se posebno odnosi na mlađe zaposlenike) ali i u nošenju sa uslovima neizvjesnosti zaposlenja. Pri tome, isticanje važnosti preuzimanja individualne odgovornosti zaposlenika za vlastitu zapošljivost trebala bi biti jedna od važnijih poruka koju psiholog šalje zaposleniku.

\section{Zaposlenici preuzimaju odgovornost za vlastitu zapošljivost}

Pitanje opstanka na trenutnom radnom mjestu nije uvijek ključno i ono koje generira najveću razinu anksioznosti. U uslovima života koje sve više karakteriše kontinuirani porast troškova života, stanarine, cijene potrošačke korpe, praćenih restrikcijama u državnim budžetima, bitno je „,biti zaposlen,,. Zabrinutost $u$ vezi sa osiguranjem statusa zaposlenosti nadvisuje zabrinutost u vezi sa zadržavajnem konkretnog posla. Na putu ostvarenja tog cilja stoji potencijal za sticanjem kompetencija koje mogu skoro pa univerzalno biti primjenjive na istim ili sličnim radnim mjestima. Takva snaga koja leži u posjedovanju generičkih kompetencija osigurava veću zapošljivost zaposlenika i osnažuje njihovo samopouzdanje u vezi s tim da će, ukoliko izgube trenutni posao, imati veću šansu da pronađu novi posao.

Uloga organizacije, kako je već naznačeno, ovdje može biti vrlo važna. Nastojeći u svoje programe brige o zaposlenim u uslovima neizvjesnosti radnog okruženja unijeti i trening ili edukaciju iz ovladavanja (određenim) generičkim kompetencijama, organizacija postiže više ciljeva. Najočigledniji jeste obuka i usavršavanje zaposlenika za rad, a posredno sve to ima značajan 
psihološki efekat. On se ogleda u tome da zaposlenici stiču dojam o tome da je organizaciji stalo do njih i da brine o svojim zaposlenim. Takav stav povećava vjerovatnost za to da će zaposlenici zadržati ili intenzivnije osjećati privrženost organizaciji. Kao posljedica, ovo nerijetko vodi oblikovanju i drugih pozitivnih stavova prema organizaciji, te pozitivnih oblika radnog ponašanja, poput ulaganja većeg napora u obavljanje svakodnevnih radnih aktivnosti.

No, realnost je takva da će organizacije biti sve manje spremne obećavati sigurnost zaposlenja, a značajna se promjena ogleda i u tome da će pojedinac sve više i u sve većem obimu sam snositi odgovornost za izvjesnost svog zaposlenja u budućnosti. I dok će stremljenje ka očuvanju zaposlenja u okviru jedne organizacije postati stvar prošlosti, borba za sticanje ili očuvanje „zapošljivosti,, na tršištu rada postati će glavno oruđe u rukama zaposlenika koji se aktivno nose sa neizvjesnošću koju budućnost sobom nosi. S obzirom da će planiranje zaposlenja i karijere u budućnosti postati vrlo težak zadatak, jedino sa čim zaposlenik može računati jeste rad na vlastitom usavršavanju, briga o tome da svojim kompetencijama adekvatno odgovara na sve izazovnije standarde izvrsnosti u radu, pravovremeno donosi dobre poslovne odluke, brine se sam o postizanju zadovoljstva poslom itd. (Kiechel, 1987: 81, prema Jacobson i Hartley, 1991). Ovakve okolnosti trebaju biti naznačene mladima još u periodu njihovog formalnog obrazovanja ali i kasnijeg profesionalnog usavršavanja. Globalno ozračje nesigurnosti i vrlo ubrzana dinamika promjena na tržištu rada samo pojačavaju osjećaj kako doživljaj individualne odgovornosti za vlastitu budućnost treba preuzeti primat $\mathrm{u}$ upravljanju individualnim akcijama ljudi. Vjerovatno se jedino na ovaj način može izbjeći nefunkcionalna infantilizacija zaposlenih koja od ljudi pravi pasivne konzumente (ne)prilika i žrtve, za čiji se nepovoljan položaj okrivljuju vanjski nekontrolabilni faktori (npr. globalno loša slika svjetske ekonomije, loše rukovođenje, nezainteresirani šefovi itd.). 


\section{Zaključak}

Formalno obrazovanje mladih zaposlenika često završava prije prvog stupanja u radni odnos. Neki tom činjenicom bivaju ohrabreni, vjerujući da je došlo vrijeme da stečena znanja i vještine ,oprobaju, u praksi, nakon godina školovanja i uloženog truda. No, bosanskohercegovačka realnost nerijetko tek tada naglasi koliko je kontinuirano ulaganje u obrazovanje važno i nakon završetka formalnog obrazovanja i sticanja željenog zvanja. I to na najmanje tri načina:

- kada mladi ljudi shvate da tržište rada traži druga zanimanja, te u nastavku obrazovanja vide svoje šanse za pronalazak zaposlenja;

- kada na svom radnom mjestu vide da je ulaganje u znanje i vještine vjerovatno jedan od najboljih načina aktivnog nošenja sa neizvjesnim radnim okolnostima;

- kada opaze da radni trendovi postavljaju sve veće zahtjeve za povećanjem i obima i kvalitete kompetencija zaposlenih, pri čemu ih ujedno obavezuju na kontinuirano usavršavanje.

Jasno je da se kod nekih pojedinaca motivacija za nastavak obrazovanja oblikuje oko jednog, dva, a kod nekih i oko sva tri navedena načina razmišljanja.

Visoka stopa nezaposlenosti, niska stopa aktivnosti, neusklađenost ponude i potražnje za radnom snagom, kao i niska mobilnost radne snage predstavljaju osnovne karakteristike tržišta rada u $\mathrm{BiH}$, prema rezultatima studije CPU-a (Centar za politike i upravljanje) od aprila 2011. godine. Kao značajne antecedencije ovakvog stanja na tržištu rada u $\mathrm{BiH}$, studija ističe zabrinjavajući trend smanjenja radno sposobnog stanovništva (nastao kao rezultat smanjenja prirodnog priraštaja i migracije), neadekvatnu ponudu radne snage kao i neusklađenost ili nepovezanost obrazovnog sistema i tržišta rada. Percepcija ovakve nepovoljne slike na tržištu rada suprotstavlja se tendencijama optimističnog gledanja u budućnost zapošljavanja mladog kadra. No, umjesto da ovakvo stanje generira pesimizam i pasivan odnos prema okruženju, ono treba pozvati na preuzimanje odgovornosti za uvođenje konstruktivnih promjena. U tom smislu, posebno se ističe uloga kreatora obrazovnih politika, tržišta rada i poslodavaca.

Prilagođavanje sve promjenjivijim i nepredvidljivijim radnim uslovima, koje karakteriše povećana nesigurnost posla nije i ne smije biti isključiva obaveza pomenutih struktura, već i svih zapolenika. Povećanje svijesti o tome da će neizvjesnost radne situacije vjerovatno rasti s vremenom, a sa njom 
i negativne posljedice, trebalo bi djelovati poticajno u smjeru preuzimanja individualne odgovornosti za vlastitu budućnost. Zaposlenici trebaju biti i te kako svjesni toga i kontinuirano raditi na ažuriranju svojih znanja i vještina u skladu sa anticipacijom novih zahtjeva u budućnosti, gdje fleksibilnost, spontanost i nepredvidivost zauzimaju istaknutu poziciju. Redizajniranje radnih mjesta, sve veća prevalencija ugovora na određeno vrijeme, naglašavaju karakter privremenosti i potrebe za ,preživljavanjem,,, gdje organizacije kao i pojedinci koji žele ostati „u igri,, moraju kontinuirano ulagati napor u povećanje svojih kompetencija i kompetitivnosti na tržištu rada.

\title{
TO CONTINUE EDUCATION WITH DOUBTFUL PROSPECTS - TICKET FOR THE LABOUR MARKET, TICKET FOR THE EMPLOYMENT AGENCY OR A GOOD MANAGEMENT STRATEGY?
}

\begin{abstract}
- Abstract -
One of the, with increased regularity accented, interpretations of the bosnian-herzegovinian context suggests that institutions of higher education and the labour market implement two (inappropriately) separated policies. At the same time, young people try to improve their chances on the labour market through own assessment of risks and possibilities which might emerge if they continue their education. Is this investment (of time, material resources, enthusiasm) really convenient or at least proportional to the value of the expected outcome? It seems that this hypothesis will not be seriously considered before a person faces the (im)possibility of finding a job in her/ his profession or faces the challenge of keeping a job, once she/he entered the labour market
\end{abstract}

Keywords: insecure employment, younger employees, education system, education and training in working organisations. 


\section{Literatura}

- Bertrand, R. M., Lachman, M. E. (2003). Personality Development in adulthood and old age. U Weiner, B., Greedheim, D. K., Lerner, R. M., Easterbrooks, M. A., Schinka, J. A., Mistry J. (Ur.). Handbook of psychology: Developmental pschology (463 - 487). New York: John Wiley \& Sons.

- Cheng, G. H.-L., Chan, D.K.-S. (2008). Who Suffers More from Job insecurity: A Meta-Analytic Review. Applied psychology: An International Review, 57 (2), 272-303.

- CPU- Centar za politiku i upravljanje. Analiza politika u oblasti povezanosti obrazovnog sistema i tržišta rada u Bosni i Hercegovini, april, 2011. Pristupljeno 9.10.2011., $8.00 \mathrm{~h}$ na http://www.cpu.org.ba/ files/CPU $\% 20$ Povezanost $\% 20$ trzista $\% 20 \mathrm{rada} \% 20 \mathrm{i} \% 20$ obrazovanja. pdf.

- De Bustillo, R. M., De Pedraza, P. (2010). Determinants of job insecurity in five European countries. European Journal of Industrial Relations, 16(I), 5-20.

- Jacobson, D., Hartley, J. (1991). Mapping the Context. U Hartley, J. Jacobson, D., Klandermans, B., van Vuuren, T. (Ur.) Job Insecurity: Coping with Jobs at Risk (2-22), London: Sage Publications.

- MacDonald, R. (1999). The road to nowhere: Youth, insecurity and marginal transitions. U Vail, J., Wheelock, J., Hill, M. (Ur.). Insecure times: living with insecurity in contemporary society. New York: Routledge.

- Maslić Seršić, D., Trkulja, J. (2009). Nesigurnost posla kao predmet istraživanja u psihologiji: teorije, operacionalizacije, nalazi. Društvena istraživanja, vol. 8, No 3 (101).

- Robinson, O. C. (Maj, 2011). Quarterlife Crises And Why They Can Be Good For You. British Psychological Society Annual Conference, Glasgow, Scotland

- Schaie, K. W., i Willis, S. L. (2001). Psihologija odrasle dobi $i$ starenja. Jastrebarsko: Naklada Slap.

- Šverko, B. (1991). Značenje rada u životu pojedinca: radne vrijednosti, važnost rada i alijenacija. Uvod u psihologiju, 15-56. Zagreb: Prosvjeta.

- Vujić, D. (2003). Obrazovanje i obučavanje. U Čizmić, S., Kondić, V. (Ur.). Priručnik: Psihologija rada u formuli uspeha organizacije (43-63), Beograd: Centar za primenjenu psihologiju. 



\section{MEDIJSKA KONSTRUKCIJA KOLEKTIVNIH SJEĆANJA: TRETMAN PROŠLOSTI U POLJU NOVINARSTVA, S OSVRTOM NA POSTDEJTONSKU BOSNU I HERCEGOVINU}

\section{- Sažetak -}

U radu kritički sagledavamo prakse obrade događaja prošlosti u polju novinarstva, odnosno medije kao distinktivnu institucionalnu arenu suvremenih zajednica za uspostavljanje, održavanje i mijenjanje zajedničkih okvira razumijevanja i komemoriranja odabranih epizoda povijesti. Nastojimo ponuditi plauzibilna objašnjenja u pogledu odnosa između ,, kultura sjećanja,, $i$, ,kulture vijesti,.. Članak sugerira kako pristupiti nerijetko neshvaćenom području prošlosti u informativnoj djelatnosti, koja u svom djelokrugu, po definiciji, nema dimenziju povijesti nego socijalne situacije suvremenosti. Također, modeliramo ključne operacije i strategije operativne u oblikovanju repertoara novinarskih naracija prošlosti. Opisane prakse ispitujemo na primjeru postdejtonske BiH, analizirajući novinarski tretman konfliktnih žarišta nedavne ratne povijesti. Legitimiziranje etnonacionalnih vizija prošlosti posredstvom diskursa vijesti prepoznajemo kao dominantni rad u „,medijskom memorijskom polju,.. Ističemo dva ključna paradoksa takvih obrazaca obrade prošlosti: supostojanje međusobno oprečnih diskursa sjećanja i kodificiranja iskustava abjekcije istim skupovima signifikacija koji su i inducirali same ratne traume. Ukazujemo na najmanje dva uvjeta koja omogućavaju ove proturječnosti: neodređenost prošlosti, koncepcija vremena koju pretpostavlja postdejtonska BiH kao inherentno nedovršenal nesavršena država, i tehnologije kulturalizirianog upravljanja traumom, koje režimi „,terapeutske/tranzicione pravde,, upošljavaju kod ovladavanja uznemirujućom prošlošću u postkonfliktnim zajednicama.

1 Dr. sc. Mirza Mahmutović, Filozofski fakultet, Odsjek za žurnalistiku, Univerzitet u Tuzli, e-mail: mirza.mahmutović@untz.ba. 
Ključne riječi: polje novinarstva, diskurs vijesti, kulture sjećanja, traumatične memorije, postdejtonska BiH.

\section{Uvod}

Procesi proizvodnje, širenja i usvajanja znanja o povijesti i društvenointegrativnim figurama sjećanja neke zajednice, danas su neodvojivi od masovnih medija. Portreti prošlosti koje stvaraju i nude mediji u različitim žanrovima svoje produkcije - od fikcijskih, preko dokumentarističkih do faktografskih poruka - značajno uvjetuju naše percepcije ne samo prošlih nego i sadašnjih socijalnih situacija. Lični i kolektivni identiteti, također, nezamislivi su bez mnogobrojnih ,vještačkih memorija, pohranjenih u medijskim arhivama, koji nam omogućavaju da „doživimo,, prošle događaje, iako su se zbili mnogo prije vremenskog horizonta našeg života. Ipak, u dominantnim, paradigma medijske pismenosti, kao i andragoškim pedagogijama evidentno je odsustvo svijesti o ulozi medija u procesima simboličke konstrukcije prošlosti.

U ovom radu ukazujemo na značaj medija, posebno novinarske profesije, u oblikovanju javnog diskursa o prošlosti. Članak je organiziran u tri dijela. U uvodnom odjeljku sažeto prikazujemo ulogu medija u procesima oblikovanja kolektivnih memorija, te ukazujemo na važnost novinarstva, kao javnog foruma za odgovorno izražavanje različitih mišljenja, u kritičkom preispitivanju prošlosti. Također, sugeriramo kako pristupiti, nerijetko neshvaćenom, području prošlosti u informativnoj djelatnosti, koja u svom djelokrugu, po definiciji, nema dimenziju povijesti nego socijalne situacije suvremenosti. U drugom dijelu, zatim, razmatramo procese izgradnje „spirala signifikacije,, posredstvom kojih se tvore medijski diskursi sjećanja/ pamćenja, dakle, ključne operacije i strategije operacionalne u oblikovanju repertoara novinarskih naracija prošlosti. I, u konačnici, u trećoj sekciji rada prikazujemo ključna obilježja medijskog tretmana konfliktnih žarišta recentne ratne povijesti u postdejtonskoj $\mathrm{BiH}$.

Rad nastaje iz uvjerenja da bez poznavanja složenih praksi, operacija i strategija obrada prošlosti u polju medija, procesi medijskog opismenjavanja i cjeloživotnog obrazovanja ostaju uskraćeni za društveno značajan skup kritičkih znanja. Važnost razumijevanja medijskog tretmana prošlosti smatramo posebno važnim u postkonfliktnim zajednicama, poput postdejtonske $\mathrm{BiH}$, gdje je oblikovanje sjećanja na uznemirujuću prošlost bitan uvjet demokratske konsolidacije bh. društva i države. U tom smislu, stjecanje kompetencija za kritičku evaluaciju pojednostavljenih, mitoloških i 
ideoloških prikaza povijesti nerazlučivo je od obrazovanja samog građanskog etosa - sposobnosti za racionalno, argumentirano i odgovorno rezoniranje u prostorima javnosti.

\section{Aktuelna prošlost: kultura vijesti i kulture sjećanja}

U suvremenom društvu masovni mediji su neizostavno polje uspostavljanja, održavanja i mijenjanja zajedničkih okvira razumijevanja svijeta prošlosti. Oni su, zapravo, jedna od najefikasnijih institucionalnih arena za širenje i učvršćivanje onih diskursa sjećanja koji u nekoj društvenoj zajednici žele osigurati dominantan pogled na prošlost. S druge strane, mediji su također jedan od najpodesnijih javnih foruma za kritičko propitivanje dominantnih (elitnih) naracija prošlosti. Iako su „medijske reminiscencije,, u pravilu, pojednostavljene i dekontekstualizirane pripovijesti, koje, nerijetko, pogoduju i služe ideološkim (zlo)upotrebama povijesti, emancipativni potencijal medija u odnosu prema prošlosti - mogućnost da potaknu odgovornu, racionalnu i argumentiranu raspravu o ,kontroverznoj, prošlosti, problematiziraju produkciju mitologiziranih i popularnih historija, te promoviraju kritičke kulture sjećanja - nikada ne treba zanemariti.

Procesi oblikovanja kolektivnih memorija ${ }^{2}$ u modernom dobu neodvojivi su od medija, shvaćenih u najširem smislu kao skup svih materija, modaliteta i institucija posredstvom kojih se odvija komuniciranje.

Prije svega, masovni mediji „obnavljaju memorije,, (Hoskins, 2008). Tragove prošlosti, povijesne pojavnosti jedinstvene i neponovljive po svojoj naravi, mediji čine trajno pristupačnim, ponovljivim momentima. Čin skladištenja, naime, pretpostavlja operaciju perpetuiranja: mogućnost

2 Općenito kazano, kolektivna memorija odnosi se na klasu socijalnih pojava koje se tiču javne upotrebe prošlosti (Kuljić, 2006). Tri referencijalne jedinice - korpus znanja o/iz prošlosti, relativno uniformirana i distinktivna predstava prošlosti koju dijele članovi skupine te kulturno osmišljen odnos spram prošlosti (Dudai, 2002) - uzimamo za matrice kolektivne memorije. Organizirano društveno pamćenje, u tom smislu, ne iscrpljuje se u pukom skladištenju iskustva iz prošlosti. Njegova važnija funkcija je „strukturiranje rezultata aktivnosti opštenja, kojima grupa određuje osoben odnos prema sebi i svijetu,, (Kuljić, 2006: 8), i to ne samo (selektivnim) čuvanjem određenih sadržaja prošlosti nego i (organiziranim) zaboravom drugih. Studije memorija interesiraju se za društvene, političke, kulturne, ekonomske i tehnologijske činioce koji uvjetuju što, kako i zašto društvene skupine pamte i/ili zaboravljaju iz povijesti. U fokusu izučavanja su obrasci koji reguliraju procese društvene obrade znanja, vjerovanja i percepcija o prošlosti, planske i/ili spontane prakse čuvanja, prenošenja, nasljeđivanja, dorađivanja, izmišljanja, preinačavanja, potiskivanja i zaboravljanja sadržaja prošlosti. Za detaljnije o konceptu, genezi studija, teorijama, dimenzijama, opcijama, institucijama i zajednicama kolektivne memorije pogledati Kuljić (2006); Assmann (2008); Assmann (2011); Nora (2007); Connerton (1989); Misztal (2003); Wertsch (2004); Olick, Vinitzky-Seroussi \& Levy (2008). 
naknadnog reproduciranja, aktualiziranja sačuvanog sadržaja. U tom smislu možemo govoriti o medijima kao „produžecima memorija,,, tehnološkim surogatima za buduće publike u procesu spoznavanja prošlosti. Otuda je svaki medijski posredovan trag prošlosti u osnovi sadržaj namijenjen predanju, razmjeni, samoj komunikaciji. ${ }^{3}$ Historija masovnih medija to zorno svjedoči. Vidljivo je to kod pisma, koje je kao ,produžetak,, memoriji omogućilo neslućeno protezanje ljudskih iskaza u svrhu ponovnog primanja poruka, preko štamparstva, koje je omogućilo njihovo umnožavanje, sve do mobilnih elektroničko-digitalnih audiovizuelnih medija, koji su omogućili registriranje, pohranjivanje te ponavljanje i sasvim neočekivanih događaja. Mogućnost mehaničkog ponavljanja ad infinitum onoga što se egzistencijalno nikada ne može ponoviti, bitno je obilježje medijskog svjedočenja prošlih zbivanja.

Ipak, svaki proces obnavljanja neizbježno uključuje preobrazbe, zastarijevanja, izmještanja, diskreditiranja, u osnovi, nova o(be)smišljavanja autentičnih elemenata. „Amnezijski efekt,, neminovna je pojava u procesu obnavljanja memorija, bez koje je teško razumjeti, kako tvrdi Andrew Hoskins, načine pomoću kojih moderno društvo živi sa svojom prošlošću i mijenja je u sadašnjici (Hoskins, 2008: 155). U tom kontekstu, indikativni su uvidi o „kanibalizacijama memorija,, u globalnim tokovima vijesti (Zelizer, 2011): nizu procesa operativnih prilikom novinarske upotrebe arhivskog materijala, posredstvom kojih „lokalni mnemonički impulsi, bivaju uprošćeni, dopunjeni, izmješteni i preneseni u globalne kontekste, u konačnici, potpuno ili djelomično izmijenjeni. S popularizacijom i sveprisutnošću digitalno-mobilnih tehnologija ovi trendovi postaju još naglašeniji. Tako osim novinara, koji rutinski koriste mnogobrojne „blic memorije,, i prateće ,interpretativne obrasce,, s ciljem određivanja značenja aktuelnim događajima, u „memorijskim sklapanjima,, (Reading, 2011) u novomedijskom umreženom okruženju također sudjeluju i pojedinci-svjedoci zbivanja kao i razne heterogene skupine globalnog civilnog društva (mreže boraca za ljudska prava, udruženja socijalno marginaliziranih skupina, umjetničkih i znanstvenih aktivista itd.).

Sklopovi sjećanja, koji se obrazuju u ovom ,globitnom memorijskom polju, ${ }^{4}$ hibridni su konstrukti, sastavljeni podjednako kako od medijski

3 Ne iznenađuje stoga što i Jan Assmann, autor teorije o kulturnom pamćenju, ovaj fenomen sagledava $\mathrm{u}$ kontekstu ponovo primljene poruke u okviru rastegnute komunikacije situacije (Assmann, 2008: 24-25), vanjskog područja komunikacijskog sistema nekog društva gdje se kulturni smisao može izmjestiti, pohraniti i ponovo uključiti, odnosno prenijeti u transgeneracijskom slijedu.

4 „Globitno memorijsko polje,,, kovanica riječi globalizacija i digitalizacija (bit kao osnovna jedinica digitalnih podataka), plodotvorni je koncept koji je razvila teoretičarka Anna Reading prilikom 
pohranjenih momenata nekog zbivanja tako i različitih kognitivnih, emocionalnih i vrijednosnih struktura koje akteri uključeni u borbu oko proizvodnje, cirkulacije i osiguranja memorijskih kapitala projiciraju na ove tragove prošlosti. Medijske reminiscencije, otuda, treba razumjeti kao dinamičke kategorije, uvijek u procesu transformacije. Ovaj paradoks između originalnosti događaja i njegove medijske reprodukcije, čime se jedinstvenost događaja u procesu medijskog svjedočenja ukida, jedno je od ključnih pitanja u studijama medija i kolektivnih memorija.

U prostorima medija uspostavljaju se i sankcioniraju „mjesta sjećanja, suvremenih zajednica, društvenointegrativne vizije prošlosti, koje kulturno-političke elite upotrebljavaju s ciljem oblikovanja kolektivnih identiteta. Zapravo, mediji su u današnjem dobu ,jedan od glavnih faktora u kreiranju znanja o historiji i ljudskom sjećanju,, (Erjavec, 2011: 40, op. aut.). Pojednostavljene, personalizirane i lako shvatljive historije koje mediji stvaraju u cjelini svoje - informativne, zabavne, dokumentarne, obrazovne i dr. - produkcije, pri tome su posebno važne za politiku, „koja ih efikasno (is)korištava za vlastitu instrumentalizaciju, u aktuelne političke svrhe i za mobilizaciju ljudskih masa,, (ibidem). Uprošćeni, dramatizirani i spektakularni prikazi povijesti, također, podjednako su interesantni i profitnoj logici tržišta, suvremenoj industriji zabave, koja obiluje produktima iz kategorije „historijskih žanrova,.. Nije pretjerano reći da najveći broj ljudi danas o povijesti uči posredstvom televizije (Edgarton \& Rollins, 2001), kao i da fikcijski i dokumentaristički televizijski portreti prošlosti značajno preobražavaju način na koji mislimo i doživljavamo različite historijske ličnosti, događaje i epohe. ${ }^{5}$

istraživanja suvremenih kultura sjećanja, obrazovanih posredstvom digitalnih tehnologija u okrilju transnacionalnih procesa. Digitalne tehnologije, smatra Reading, konstituiraju nova polja za oblikovanje kolektivnih memorija, koja su istovremeno i algoritamska, geografska i fizička. Kao polimorfni mediji (Hansen, 2006), digitalne tehnologije premašuju distinkcije producent - konzument, javno - privatno, organsko - anorgansko, karakteristične za jednosmjerni model komuniciranja elektronskog doba, stvarajući uvjete za nastanak novih oblika memorijalnih praksi. $\mathrm{Na}$ tragu Deleuzea, Reading tako piše da su memorijska sklapanja u globitnom polju organizirana oko dvije ose: materijalnih praksi i diskurzivnih formacija producenta i konzumenta (tzv. prosumera), koje se dalje konsolidiraju i/ili preobražavaju kroz drugu osu, procese teritorijalizacije i deteritorijalizacije, gdje se vode bitke nad sklapanjem, mobilizacijom i osiguranjem memorijskih kapitala između pojedinaca, nacionalnih, supranacionalnih institucija i transnacionalnih aktera.

5 Kao dokaz tvrdnji dovoljno je navesti samo neke od aktuelnih popularnih televizijskih dramskih serija poput „Obitelj Borgia,,, „Spartak: krv i pijesak,, ,Sulejman Veličanstveni,,, „Tudori,, ,Rim,,, „Vikinzi,, i dr. Također, programski paketi koje nude kablovski operateri obično sadrže nekoliko dokumentarnih programa povijesne tematike. Selekcija tema i način njihovog izlaganja u biti slijede logiku medijske konstrukcije zbilje. 
Ipak, uloga medija u procesima oblikovanja kolektivnih memorija posebno postaje izražena u uvjetima novomedijske ekologije. Primarno se to odnosi na momente socio-kulturnih trauma, kao što su konflikti, krize i katastrofe, tzv. ,prelomni događaji,, u memorijskim kulturama. Opsesija medija za arhiviranjem traumatičnih događaja, omogućena elektronsko-digitalnim mobilnim tehnologijama, uspon praksi „,medijskog svjedočenja, ${ }^{6}$ u kojima se prožimaju producenti i konzumenti (tzv. prosumeri), profesionalno i tzv. građansko novinarstvo, učinila je medije neizostavnim elementom suvremenih kultura sjećanja. Od Zaljevskog rata, rata u $\mathrm{BiH}$, preko terorističkih napada na New York, London i Madrid, „rata protiv terorizma, u Afganistanu i Iraku, sve do ,arapskog proljeća,, uragana „Katrina,, tzunamija u Indoneziji i Japanu mediji posreduju i arhiviraju slike tragedija u realnom vremenu. Prije, $u$ toku i poslije traumatičnih događaja. Mediji tako postaju stalni pratioci trauma sposobni ne samo da pruže prvu utjecajnu definiciju traumatičnih događaja nego i da konstantno prate, oblikuju i nameću njihova pojavljivanja u javnom diskursu i nakon traumatičnih događaja.

Digitalni mediji, zapravo, radikalno preobražavaju odnose pamćenja i zaboravljanja karakteristične za moderno doba (Gared-Hansen, Hoskins \& Reading, 2009). U svijetu opčinjenom prekomjernom povezanošću umnožavanjem, uređivanjem, povezivanjem, dijeljenjem, komentiranjem, „lajkanjem,,-sjećanje postaje pravilo a zaborav izuzetak (Mayer-Schönberger, 2009). Andrew Hoskins u tom kontekstu piše o „postoskudnom dobu, (Hoskins, 2013), ukazujući na strukturne promjene koje su u suvremeno društvo unijele digitalne multimedijalne baze podataka, sposobne teorijski za neograničene mogućnosti pohranjivanja, obrađivanja i nadzora svih vrsta podataka. Nije iznenađujuće što kritičari novih medija, poput Geert Lovinka, pišu o „društvu upita,, aludirajući na „googlizaciju naših života, čija su okosnica upravo baze podataka (Lovink, 2011). Web 2.0 tehnologije, tzv. društveni mediji, indikativni su primjeri suficitarne produkcije tragova o prošlosti. U ovim kvaziprivatnim i polujavnim prostorima svaki momenat života, čak i najbanalnije epizode, smatraju se poželjnim i skladištenja vrijednim podacima. U takvoj prekomjernosti informacija o prošlosti, zaboravljanje kao poništavanje ili rasterećenje informacija imat će sve veću ulogu u društvu 21. stoljeća (Connerton, 2008: 65).

6 Pod izrazom „,medijsko svjedočenje,, podrazumijeva se ,istovremeno pojavljivanje svjedoka u medijskim izvještajima, mogućnosti samih medija da svjedoče te pozicioniranje medijske publike kao svjedoka prikazanih događaja, konfiguracija koja se zgodno može sažeti kroz tripartitnu distinkciju između svjedočenja $u$ medijima, svjedočenja pomoću medija i svjedočenja kroz medije,, (Frosh \& Pinchevski, 2009: 1). 
U cjelokupnim studijama medija i kolektivnih memorija, informativna djelatnost zasigurno spada među najslabije istražena područja. Tek su novije interdisciplinarne studije posvetile pažnju značaju novinarstva u izgradnji, održavanju i mijenjaju javnih percepcija, osjećaja, vjerovanja i znanja o prošlosti. ${ }^{7}$ U konvencionalnom shvaćanju uočljiva je dvostruka marginalizacija novinarstva: slabo razumijevanje funkcije novinarstva u radu kolektivne memorije s jedne strane, ali i odsustvo svijesti o funkciji prošlosti u radu novinarstva s druge strane (Zelizer, 2008: 80). U radovima ključnih teoretičara kolektivne memorije, tvrdi Zelizer, uloga novinarstva nikada nije sistematično izučavana. Također, isto vrijedi i da važnost novinarstva $u$ posredovanju prošlosti nerijetko nije prepoznata ni kod samih novinara koji „,niti eksplicitno pričaju o prošlosti niti prošlost uzimaju u obzir kao dio svog očiglednog djelokruga, (ibidem). Pomnije ispitivanje, međutim, ne podržava ova uproštena konvencionalna shvaćanja.

Kako ukazuje Carolyn Kitch, novinarstvo je jedno od središnjih mjesta sjećanja suvremenog društva (Kitch, 2008: 311). Velik dio onoga što znamo o prošlosti dolazi iz medija. Naše percepcije o prošlosti u velikoj mjeri su određene novinarskim perspektivama, a novinarski registri o prošlosti važan su izvor informacija o događajima, praksama i temama nekog prošlog vremena pa su u tom smislu neizostavna komponenta memorijskih kultura. Posebno je to izraženo kod novinarske obrade komemorativnih događaja, naročito obljetnica, koje mediji koriste da bi reinterpretirali javne ideale i društveno (ne)poželjne figure sjećanja, ali i predstavili sebe kao neizostavne hroničare društvene zajednice, koji značajno uvjetuju oblike i retoriku komemorativnih rituala. $^{8}$

S druge strane, prošlost je također neizostavni dio same novinarske profesije. Vijesti, naime, zahtijevaju kontekste pomoću kojih se novost tumači i razumijeva. Novinari su upućeni na prošlost i aktivno je koriste u razumijevanju sadašnjosti. Jill Edy je novinarsku upotrebu prošlosti

7 Pogledati, naprimjer, radove Zelizer (1992, 2008), Edy (1999, 2006), Kitch (2002; 2008), Schudson (1992), Nieger, Meyers \& Zandberg (2011), Zandberg (2010), Philips (2004) i dr.

8 U istraživanju obljetničkih novinarskih formi u Sjedinjenim Američkim Državama Kitch piše: „Danas su masovni mediji središnji za američko razumijevanje prošlosti. Obilježavajući jubileje događaja - od Pearl Harbora do Woodstocka do I Love Lucy - filmovi, publicistika i televizijski specijali reinterpretiraju njihovo trajno značenje za državu, koristeći ove priče da razmotre američke ideale i identitet.,, (Kitch, 2002: 44-45). Slične prakse uočljive su i kod bh. medija. Tako je najstariji bh. dnevnik „Oslobođenje,, u specijalnom izdanju povodom 70. obljetnice (br. 23968 od 30. 8 .2013.) reproducirao, prema izboru uredništva, najznačajnije događaje o kojima je izvještavao od 1943. godine. Podsjećajući na događaje koji su obilježili suvremeno doba, mediji na ovaj način nude svojevrsne referentne tačke sjećanja posredstvom kojih zajednica sagledava, prepoznaje i modificira identitetske obrasce kroz vrijeme. 
razvrstala u tri kategorije: komemoracije, historijske analogije i historijske kontekste (Edy, 1999: 71). Komemorativne tekstove novinarske organizacije koriste kako bi publiku podsjetili na važne društvene događaje, ali i (de) legitimizirali različite skupove narativnih repertoara prošlosti koje društveni akteri promoviraju u javnoj sferi. Osim podsjećanja na javno značajne epizode povijesti, novinari nerijetko povlače i paralele između suvremenih i nekadašnjih događaja, odnosno, nastoje situirati aktuelne situacije u šire povijesne kontekste. Historijske analogije i kontekstualizacije tako novinarskim organizacijama nude pozicije autoriteta u upotrebi prošlosti pri objašnjenju sadašnjosti, i obratno. Prošlost i historija, ne treba zaboraviti, omiljene su teme i u popularnoj kulturi. Kitch je uočila kako se istraživanja o odnosu medija i kultura sjećanja većinom fokusiraju na analize izvještavanja „elitnih,, medija o „ekstremnim,, događajima (poput ratova, atentata, prirodnih nepogoda i sl.) u formama tzv. ,tvrdih vijesti,, (hard news) dok se narativno novinarstvo (feature journalism), tzv. „mekše vijesti,, (soft news) obično zapostavljaju. Ove tradicionalno ,ženske strane štampe,,, tzv. tematski okvir „4F, (food, fashion, family, furnishing) isto tako obiluju retrospektivnim sadržajem: člancima o „retro,, modi i dekoracijskim stilovima, velikim momentima u sportskoj i filmskoj historiji, profilima nekadašnjih poznatih osoba (tzv. where-are-they now celebrity profiles), obljetnicama događaja iz historije lokalnih zajednica itd.

Jedan od vjerovatno najvećih izvora nesporazuma $\mathrm{u}$ razumijevanju uloge novinarstva u procesima oblikovanja kolektivnih memorija jeste očigledna, samorazumljiva isključenost $i$ odsustvo prošlosti iz same definicije informativne djelatnosti. Donekle se, zapravo, i čini paradoksalnim povezati „kulture sjećanja,, usmjerene ka obradi sadržaja prošlosti, i „kulturu vijesti,, (Allan, 2004), koja u svom središtu ima novost, socijalne situacije suvremenosti, same aktuelne događaje današnjice. Kako, stoga, prevazići ove proturječnosti? Kako prošlost može ući u prostore medija i postati predmetom novinarske obrade? Odgovor je jednostavan: kao i sve druge medijske teme, samo u obzoru (diskursa) vijesti. Drugim riječima, kao aktuelna prošlost.

Naime, informativna produkcija, odnosno, vijest predstavlja središnji rad u polju novinarstva. Prošlost, prema definiciji ${ }^{9}$, nije predmet žurnalizma nego suvremenost, dakle, dimenzija sadašnjosti/aktualiteta, događaji današnjice (žurnalizam od fr. jour, dan, journal, dnevni). U pravilu, novinari se ne bave

9 „Novinarstvo je djelatnost ili praksa produkcije i diseminacije informacija o suvremenim temama od općeg javnog interesa i važnosti. To je djelatnost skupa institucija koje periodično publiciraju (obično dnevno) informacije i komentare $o$ suvremenim temama, u pravilu predstavljene tačno i istinito, raspršenoj i anonimnoj publici s ciljem javnog uključenja publike u diskurs za koji se drži da je javno značajan.,, (Schudson, 2003: 11). 
poviješću, izuzev ako teme prošlosti nisu (re)aktualizirane kao bitna pitanja suvremenosti, samog razumijevanja današnjice. Prošlost u medijima nastupa uvijek kao aktualna prošlost, pri čemu su sami kriteriji (re)aktualizacije tema prošlosti bitna, ako ne već i ključna, analitička dimenzija. Izrazom ,aktualna prošlost,, želimo ukazati upravo na prožimanje sadašnjosti i prošlosti: istovremeno su to i aktualni događaji, teme relevantne za sadašnje (i buduće) socijalne situacije, i događaji prošlosti, teme strukturno upućene na ranija, prošla zbivanja. Prošlost, stoga, može ući u medije samo u obliku informativno vrijednog događaja, dakle kao vijest. Tretman prošlosti u informativnoj djelatnosti uvjetovan je kriterijem vijesti, te se u skladu s ovim produkcijskim načelima (uz također principe simplifikacije i selektivnosti) medija mora i razumijevati. Polazeći od ovih stajališta u nastavku ćemo nastojati osvijetliti prakse obrade prošlosti u polju novinarstva.

\section{Medijska konstrukcija kolektivnih sjećanja: prakse, operacije i strategije obrade prošlosti u polju novinarstva}

Kao institucija kolektivne memorije, novinarstvo figurira kao složeno polje produkcije značenja (smislotvorstva) prošlosti. S jedne strane, mediji su arena unutar koje različiti (moćni) društveni akteri vode „mnemoničke bitke, s ciljem priznanja određenih diskursa sjećanja u sferi javnosti. Svaki akter, u tom smislu, teži osigurati (samo) jednom skupu narativa, među mnoštvom drugih, konkurentskih prikaza prošlosti, dominantnu poziciju u javnosti, tj. učiniti jednu perspektivu povlaštenom (univerzalnom) tačkom motrišta povijesti. S druge strane, mediji su međutim i sami akteri s autoritativnom pozicijom u ovom polju, elitni članovi interpretativne zajednice društva koji aktivno usmjeravaju javnu upotrebu prošlosti. Uloga novinarstva u procesima oblikovanja kolektivnih memorija određena je ovom dvostrukom pozicijom, temeljem koje mediji istovremeno figuriraju i kao zona u kojoj se nadmeću dominantni prikazi prošlosti ali i kao aktivni „,igrači,, koji svjesno i/ili nesvjesno podržavaju, osporavaju ili ignoriraju „odabrane,, predstave povijesti koje se posreduju u areni (Zandber, 2010; Nieger, Oren \& Zandber, 2011).

Izraz konstrukcija koristimo kao sveobuhvatni pojam za označavanje praksi izgradnje značenja prošlosti, kognitivnog rada u polju novinarstva. Konstrukcija, u osnovi, opisuje simboličke procese/aktivnosti posredstvom kojih novinari oblikuju repertoare naracija prošlosti, a koje uvjetuju sve subjektivne (habitusi) i objektivne (strukture) sile u polju medija. Ključna radnja konstrukcije je strukturiranje značenja prošlosti: izgradnja spirala 
signifikacija ili simboličkih interpretativnih mreža koje (pred)određuju percepciju i okvire znanja prošlosti. Pojam, zapravo, opisuje „strukturirajuće strukture,, sisteme obrazaca opažanja i vrednovanja, svojevrstan kategorijalni aparat posredstvom kojeg se „kodificira, - (ra)spoznaje, imenuje, iskazuje, opisuje, vrednuje, definira, razumijeva - svijet prošlosti. Izrazom primarno želimo ukazati na društvenu uvjetovanost interpretacije prošlosti. Okviri posredstvom kojih se spoznaje, tvori i iskazuje značenje prošlosti, naime, imaju društvenu genezu, odnose koje ih omogućuju, dovode u postojanju i što je posebno važno - konstantno potvrđuju kao takve, legitimne kategorije znanja i imenovanja povijesti.

Prošlost, jedna od tri vremenske dimenzije stvarnosti, fundamentalni je resurs praksi konstrukcije. Kao aktivnost usmjerena definiranju (imenovanju) i predstavljanju (izlaganju) prošlosti posredstvom kompleksa signifikacija, konstrukcija je neodvojiva od komunikacije, simboličkog procesa pomoću kojeg se proizvodi, održava, dorađuje i preobražava (društvena) stvarnost (Carey, 2009: 19). Teorija konstrukcije prošlosti implicira teoriju masmedijske konstrukcije stvarnosti, jer tematizira proces uspostavljanja, održavanja i mijenjanja zajedničkih okvira razumijevanja (viđenja) svijeta prošlosti. ${ }^{10}$ A „kao i bilo koji drugi oskudan resurs, stvarnost je predmet nadmetanja, sukobljavanja različitih ciljeva i projekata; pridaju joj se različita značenja i mogućnosti, troši se i konzervira, racionalizira i distribuira. Temeljni oblik moći je upravo moć da se definira, podijeli i predstavi ovaj resurs.,, (Carey, 2009: 66). Prošlost se, u ovom smislu, može promatrati kao višeznačan simbolički konstrukt, u čijem oblikovanju sudjeluju različiti društveni akteri, a danas sve više mediji kao „vrhovna institucija javne sfere,, (VoćkićAvdagić, 2002). Procesi oblikovanja značenja prošlosti, samo sjećanje kao čin semiotiziranja (smislotvorstva), u biti su komunikacijski procesi u kojima zajednica i njeni vladajući slojevi nastoje povijest prikazati na jedan određen način, u nizu mogućih predstavljanja.

Procesi simboličke obrade tragova povijesti ovaploćuju se u obliku medijskih tekstova: simboličkim konstruktima, rezultatima, iskazima i

10 Izraz teorija ovdje koristimo u izvornom značenju riječi (grč. theorein - vidjeti), kao način viđenja ili perspektivu promatranja svijeta, to jeste, obrasce strukturiranja stvarnosti. Svaka struktura implicira određene principe podjela (poput dualizama muško - žensko, dobro - zlo, visoko - nisko, snažno - slabo, najstarijih načela strukturacija u ljudskom društvu) spram kojih se stvaraju odnosi smisla, i koji organiziraju - istovremeno ograničavajući tim istim okvirima - spoznaju društvene stvarnosti. Nametanje određenog viđenja stvarnosti, stoga, ne shvaćamo u smislu propagandnomanipulacijskih akcija, nego na tragu Baudrillarda i Kafke, kao kolanje određenog kôda, spram kojeg je kodificirana stvarnost, tj. utvrđene podjele - granice - koje omogućuju određene društvene (id)entitete. 
materijalizacijama praksi strukturiranja značenja prošlosti posredstvom diskursa informativne djelatnosti. „Konstrukcija,, i „konstrukt, su u dijalektičkom spoju: kognitivne, društveno uvjetovane strukture spoznavanja i imenovanja povijesti tekstu daruju značenje, to jest, diskurse sjećanja koji sadržaje prošlosti povezuju u smisleni poredak, a zauzvrat ih tekst simbolički izražava u društvenim odnosima, odnosno komunikacijskim činovima. „Konstrukcija,, i „konstrukt,, ne mogu se odrediti u smislu kauzalnih odnosa, budući da određeni regulirani skup iskaza o prošlosti jednom proizveden može biti podloga stabiliziranju društvenih odnosa temeljem kojih nastaje, dakle, njihovoj daljoj reprodukciji, ali isto tako može figurirati kao osnova za nastanak novih strukturacija, dakle, može ih (djelomično ili u potpunosti) preobražavati. Konstrukt, stoga, promišljamo kao simbolički kompleks koji nema zatvorenu nego otvorenu strukturu.

Kao što smo istakli u prethodnom dijelu, informativna produkcija, odnosno, oblikovanje diskursa vijesti predstavlja središnji (kognitivni) rad u polju novinarstva. Ako se oslonimo na „sociologiju vijesti,,, kakvu predlaže Michael Schudson, onda za (diskurse) vijesti možemo kazati da izražavaju javno(sti) značajne teme, ili kako Schudson kaže vijesti su ono što je javno(sti) značajno, odnosno, ono što je javno(sti) istaknuto kao značajno (Schudson, 2003: 6). Uvodeći kvalitetu ,javnog značaja, kao princip distinkcije, pripisujući događajima različite (informativne) vrijednosti, vijesti strukturiraju društvene situacije u odnose nejednakosti omogućujući utvrđivanje razlike u obimu (javno značajan - beznačajan) i vrsti (više-manje javno značajan) medijskog događaja. Nejednaka vrijednosti događaja, omogućena kvalitetom ,javnog značaja,,, u tom smislu temeljna je pretpostavka, uvjet važenja vijesti. Sa ,javno značajnim,, događajima postaju moguće razdiobe na one koji su u poziciji da znaju više (izvori) i manje (publika) o ovim događajima, a time i odnosi posredovanja (novinari), to jest, informiranja. ${ }^{11}$ „Javni značaj,,, međutim, nije neka takoreći „objektivna,, „prirodna,,, „supstancijalna,, kvaliteta događaja. Ova svojstva su predmet „,konvencije,,: postoje samo unutar društvenih okvira koji propisuju i određuju što je i ,javno,, i „značajno,.. Kvalitete ,javnog značaja,,, dakle, rezultat su odlučivanja. Odluke o ,javno važnim,, događajima donose se u polju medija, a njih donose urednici-novinari; uvjetovane su raznim eksternim i internim silama na kojima počiva polje novinarstva. Iako se „objektivno,, ne može ustanoviti zašto je neki događaj važniji od drugog, temeljna pretpostavka

11 Informacija je u biti relacioni - ako ne i relativni - pojam: ovisi od razine saznanja o predmetu informiranja. Apsolutno znanje, spekulativno kazano, isključuje postojanje informacije (jer posjeduje sve informacije). 
u svijetu medija je da postoji nejednaka vrijednost događaja i da njihovo razgraničavanje jeste nadležnost novinarstva. Procesi obrade vijesti u tom smislu mogu se shvatiti kao prakse odlučivanja o nizu operacija posredstvom kojih se strukturira vijest, to jest, definira i obrađuje javno značajan događaj. ${ }^{12}$

Prošlost, stoga, postaje moguća kao medijski sadržaj tek kada su teme povijesti reaktualizirane kao bitna pitanja suvremenih socijalnih situacija, samog razumijevanja današnjice. Kratko kazano, kada se povijesna zbivanja pojavljuju u obliku informativno vrijednih događaja, samih vijesti. Tretman prošlosti u polju novinarstva mora se razumjeti i istraživati u okrilju procesa obrade (diskursa) vijesti o ,javno značajnim,, epizodama povijesti. U slučaju praksi medijskih konstrukcija kolektivnih sjećanja, procesi simboličkih strukturacija prošlosti u polju novinarstva tako podrazumijevaju odlučivanje o najmanje tri ključne operacije u polju javnosti, dominantno u nadležnosti informativne djelatnosti odluke o:

- izboru relevantnih događaja - mjesta sjećanja (ili: definiranje kriterija (re)aktuelizacije tema prošlosti),

- oblicima/sadržajima medijskih diskursa sjećanja (ili: definiranje semiotičkih okvira pomoću kojih će određeni aspekti prošlosti biti definirani, organizirani i izloženi u medijima), te

- preduvjetima za stjecanje autoriteta u oblikovanju naracija o prošlosti.

U osnovi, proces konstrukcije značenja prošlosti u polju novinarstva je proces (de)legitimiranja određenih oblika znanja, razumijevanja i predstavljanja prošlosti usmjerenih javnosti. Riječ je o konstantnom odnosu osporavanja jednih (nelegitimnih) i priznavanja drugih (legitimnih) simboličkih konstrukcija ili interpretacija povijesti posredstvom diskursa vijesti. Kao vrhovna institucija suvremene javne sfere mediji su neizostavno

12 Procesuiranje masmedijske informacije pretpostavlja serije odluka o operacijama selekcije, predstavljanja i autorizacije javno značajnih događaja posredstvom kojih se oblikuje diskurs vijesti. Operacija selekcije obuhvata djelatnosti odabira relevantnih, informativno vrijednih događaja prošlosti. Preduvjet odabira je radnja razgraničenja javno značajnih - beznačajnih događaja, koje se vrši posredstvom kriterija vijesti.

Operacija predstavljanja sastoji se od dvije, međusobno uvjetovane podoperacije: izdvajanja relevantnih aspekta odabranog događaja (informacija per se) i izlaganje ovog sadržaja u obliku masmedijske poruke (informacija per nos).

Uočavanje i izdvajanje relevantnih aspekta, općenito kazano, vrši se posredstvom klasične novinarske formule , $5 W+H$,, dok se izlaganje mentalne predodžbe događaja u verbalno-simboličku strukturu odvija u skladu s novinarskim stilom, žanrom i dodijeljenim prostorom/vremenom.

Operacija autorizacije podrazumijeva verifikaciju prikaza događaja posredstvom odabranih izvora koji potvrđuju validnost konstrukcije stvarnosti pomoću diskursa vijesti. Sve tri operacije u biti su međusobno ovisne radnje i mogu se samo uvjetno, u analitičke svrhe, raščlaniti i odvojeno promatrati. 
polje artikulacije naracija prošlosti i jedno od najefikasnijih institucionalnih arena za širenje i učvršćivanje onih diskursa sjećanja koji u određenoj zajednici žele osigurati hegemonijsku poziciju. Odlučivanje o javnoj egzistenciji određene socijalne situacije, odnosno, proizvodnja posebne kulturne forme vijesti, sankcioniranje onoga što je javno(sti) značajno vrhovna je vrijednost, simbolički kapital imanentan polju novinarstva. Utjecajnost medijskih definicija prošlosti, stoga, ne proizlazi iz kvaliteta njihove eksplikacije povijesnih događaja, koji su uglavnom uprošćene i dekontekstualizirane pripovijesti, nego upravo zbog legitimiziranja određenih praksi spoznavanja i imenovanja prošlosti, koje direktno i/ili indirektno, svjesno i/ili nesvjesno novinari koriste prilikom obrade (re)aktualiziranih događaja prošlosti posredstvom diskursa vijesti. Pre(u)pisati određeni skup naracija, znanja i vjerovanja o prošlosti u svije(s)t javnosti pomoću medijskih tekstova znači učiniti date figure sjećanja priznatim, javno povlaštenim i posvećenim perspektivama sagledavanja prošlosti. Svaki narativ prošlosti teži ovom statusu: osigurati kapital medijski privilegirane, prestižne, utjecajne, dakle, javno značajne vizije prošlosti. Težnja za očuvanjem, odnosno, preobražajem određenih medijski privilegiranih definicija prošlosti u biti je permanentan proces u polju novinarstva, uvjetovan odnosima sila na kojima ono počiva.

Zato prilikom analize nije dovoljno samo promotriti kako se sjećanja oblikuju posredstvom praksi informativne djelatnosti nego i kako se pomoću odluka o operacijama strukturiranja vijesti o prošlosti vrši (strateška) afirmacija ili negacija određenog predstavljanja prošlosti kao legitimnog okvira razumijevanja povijesti. Smatramo da u tom kontekstu može govoriti o najmanje tri medijske strategije operacionalne u tretmanu prošlosti posredstvom novinarskih praksi:

- glorificiranje kristalizira događaje prošlosti u simbole pamćenja,

- osporavanje ističe međusobno suprotstavljene vizije prošlosti i

- ignoriranje ne priznaje događaj prošlosti kao relevantan memorijski resurs.

Utjecaj ovih strategija na proces odlučivanja o operacijama strukturiranja vijesti čini ove odluke strateškim, odlukama u funkciji (de)legitimacije određenog prikaza prošlosti u polju novinarstva. 


\section{Krajolici trauma i medijske reminiscencije: opća obilježja novinarskog tretmana ratne prošlosti u postdejtonskoj BiH}

Polazeći od prethodno elaboriranog modela praksi obrade prošlosti u polju novinarstva, u nastavku prikazujemo opća obilježja tretmana tema ratne povijesti u bh. informativnim medijima. ${ }^{13}$

U pogledu normi selekcije, tri sadržaja ratne prošlosti (1992-95) figuriraju kao ,izvori sjećanja,, u prostoru medija:

- iskustva nasilja i gubitaka, to jest, traumatična sjećanja, sadržaji prošlosti obilježeni iskustvima individualnih i grupnih viktimizacija, poput ubijanja, silovanja, zlostavljanja, progona, oduzimanja i uništavanja imovine i drugih oblika zločina;

- iskustva konflikta, to jest, patriotska sjećanja, epizode ratne povijesti obilježene vojničko-političkim trijumfima i porazima, poput značajnih vojnih operacija, odnosno, diplomatskih kampanja i sličnih političkih akcija tokom ratnog perioda $\mathrm{i}$

- iskustva ratnog profiterstva, to jest, nelagodna sjećanja, koja obuhvaćaju pojedinosti iz „ratne biografije,, pripadnika vladajućih elita, odnosno, prešućenu i zatomljenu ratnu prošlost „eminentnih osoba,, iz političkog, ekonomskog, kulturnog i drugog društvenog miljea.

Najznačajniji sadržaji ratne povijesti u novinarskom tretmanu prošlosti čine traumatična sjećanja ${ }^{14}$, koja se u sadržajima medija pojavljuju posredstvom

$13 \mathrm{U}$ nastavku predstavljene orijentacione karakteristike novinarskog tretmana tema ratne povijesti temelje se na podacima prikupljenim u okviru empirijskih istraživanja tokom rada na doktorskoj disertaciji „Medijska konstrukcija kolektivnih sjećanja u postdejtonskoj $\mathrm{BiH}$,, koju je autor odbranio na Fakultetu političkih nauka u Sarajevu u maju 2013. godine. Analitički korpus obuhvaćao je sadržaje reprezentativnih printanih $(\mathrm{N}=784)$ i elektronskih $(\mathrm{N}=223)$ medija, publicirane $u$ odabranim intervalima tokom 2009. i 2010. godine, koji su analizirani, između ostalih, uz pomoć metoda analize sadržaja i kritičke analize diskursa.

14 Od 1980-ih godina traumatična iskustva viktimizacija, sama negativna sjećanja, potisnula su dijalektiku trijumfa i poraza, dva ključna pola između kojih se odvijaju procesi konstrukcije kolektivnih identiteta u nacionalnim kulturama sjećanja (Assmann, 2011). U okruženju utemeljenom na idealima individualne sreće, trenutnim zadovoljstvima i čuvenosti/slavi, u težište javne svijesti ulaze, tvrdi Bauman, figure žrtve i poznate ličnosti, dok se djela heroja i mučenika, središnjih mnemotopa nacija-država i predmodernih zajednica, čine anahronim, iracionalnim i odbojnim (Bauman, 2009). Transnacionalni procesi potiču otklon od slavne, monumentalne prošlosti i razvijanje senzibilitetima prema povijesnim iskustvima viktimizacije. Naravno, riječ je o intencionalnim odnosima, budući da je transnacionalnim institucijama bitna ne toliko ,povijesna istina, koliko dozirana idejna suglasnost koja neće remetiti procese po(u)vezivanja, bile to politički motivirane integracije ili globalni tok multinacionalnog kapitala (Kuljić, 2006: 191). Nije 
novinarske obrade (izvještavanja, komentiranja i/ili analiziranja) tri vrste medijskih događaja: procesa traženja u ratu nestalih osoba, obilježavanja tragičnih datuma ratne povijesti i krivično-pravnih procesuiranja osoba osumnjičenih za ratne zločine. Ova tri makrotematska kruga predstavljaju okvire pojavljivanja ili aktualizacije traumatične prošlosti u bh. medijima. Iako je za svaki makrotematski krug moguće utvrditi serije posebnih preferencija prilikom selekcije događaja iz prošlosti, u općem smislu sve preferencije povezuje princip vijesti: potraga za neočekivanim, iznimnim, nesvakidašnjim, ekskluzivnim, senzacionalnim, spektakularnim, tajnim, nedovoljno osvijetljenim epizodama ratne povijesti, što je temeljni uvjet pojavljivanja tema prošlosti u prostorima medija.

Ispitivanje simboličkih okvira predstavljanja ratne prošlosti ukazuje na svojevrsnu „kolonizaciju,, i „monopolizaciju,, cijelog (ili značajnog dijela) diskursa o prošlosti od strane diskursa (auto)viktimizacije, što je vjerovatno jedan od značajnih činilaca dominacije traumatičnih epizoda ratne povijesti u medijskim sadržajima o nedavnoj prošlosti. Analiza je, zapravo, pokazala kako postoji jedan zajednički repertoar signifikacija, evidentan i kod međusobno suprotstavljenih prikaza ratne povijesti. Tako se prilikom artikulacije iskaza uočavaju sljedeće diskurzivne konstante: žrtve se, ali i krivci, predstavljaju u skupnim kategorijama, bilo pomoću općih (npr. izmasakrirani civili, ubijeni vojnici, nestale osobe, posmrtni ostaci itd.) ili partikularnih (etničkih) odrednica, obim stradanja se numerički kvantificira, sakralna simbolika ističe prilikom komemorativnih rituala, stravičnost viktimizacije naglašava, dok se povijesna zbivanja predstavljaju uglavnom uprošteno, nerijetko s mitološkim prizvucima. ${ }^{15}$ Zasnivanje i izgradnja spirala signifikacija na ovim narativnim osloncima ukazuje da novinarska obrada događaja prošlosti privilegira dominantne etnonacionalne diskurse, čije je ključno obilježje isticanje razlike u stradanju dva ili više kolektiva, to jest, njihovo međusobno odmjeravanje. Gramatička struktura priče tako se manje-više dosljedno koncentrira na

iznenađujuće stoga što Europska unija svoje utemeljivačke pripovijesti pronalazi u Holokaustu, ali i drugim traumatičnim iskustvima iz ,zajedničke europske povijesti,,, poput partijsko-državnih zločina, genocida, ,etničkih čišćenja,,, ,,dobrovoljnih migracija,,, kolonijalističkih eksploatacija kao i ratnih nesreća, kriza i katastrofa (Leggewie, 2011). Popularnost politika ispričavanja za zlodjela počinjena u prošlosti, ali i sve češći „,viktimizacijski nacionalizmi,, (Lim, 2010), zapravo su lice i naličje uspona kulture negativnih pamćenja. Novije memorijske kulture postdejtonske $\mathrm{BiH} \mathrm{u}$ tom smislu nisu nikakav izuzetak nego tek specifičan, lokalni slučaj, gdje su povijesna iskustva viktimizacije bila upotrijebljena kao gradivni materijali za stvaranje novih-starih etnonacionalnih zajednica (Mahmutović, 2012).

15 Na primjer, određivanje konflikta kao „odbrambeno-otadžbinskog rata,, ili „,domovinskog rata,, s implicitnom mitologijom ognjišta, majke domovine i ratničke, muške otadžbine. 
nekoliko istih pitanja, oko kojih se plete priča o ratnom događaju: koliko je i ko stradao, pri čemu je u žiži određivanja u krajnjoj instanci utvrđivanje etnonacionalne identifikacije žrtava, kakva je narav događaja boli i, što je posebno važno, ko je krivično-pravno odgovarao za zločin?

Dominantni legitimni narativni autoriteti dalje se, donekle, sami logički nameću. Riječ je o biografskim izvorima, žrtvama i udruženjima žrtava, koji imaju ,posljednju riječ,, u pogledu ,deskripcije,, ratnih trauma, i stručnopravnim izvorima, koji donose „,posljednji sud,, u pogledu „eksplikacije, povijesnih događaja, dakle, u spornom predmetu utvrđuju i imenuju „činjenično stanje,, „karakter događaja,, i ,minimalni broj žrtava,.. U dominantnim diskursima, biografski i sudski autoriteti obrazuju ,subjektivne,, i „objektivne,, polove „povijesne istine,,, između kojih se odvija medijska konstrukcija prošlosti. Ostale klase izvora (npr. institucionalni, religijski, akademski i sl.) popunjavaju ,međuprostor,, između ovih krajnosti, podupirući ili osporavajući njihov autoritet u oblikovanju predstava prošlosti.

Dominantni obrasci obrade prošlosti u ,medijskom memorijskom polju,, legitimiziranje etnonacionalnih vizija prošlosti posredstvom diskursa vijesti, polučuju najmanje dva paradoksa: supostojanje međusobno oprečnih diskursa sjećanja i kodificiranja iskustava abjekcije istim onim skupovima signifikacija koji su i inducirali ratne traume. Oslanjajući se na novije kritičke studije o postdejtonskoj BiH, posebno rad bh. politologa Nerzuka Ćurka i kulturologinje Jasmine Husanović, u nastavku ćemo pokušati pojasniti uvjete koji omogućavaju ove proturječnosti.

To što u postdejtonskoj $\mathrm{BiH}$ postoji duboka nesuglasnost o elementarnim dijelovima narativa sjećanja, naravi događaja nasilja (agresija/genocid ili građanski rat/ratni zločin), krivcu (jedna strana ili svi podjednako) i žrtava (jedan ili svi narodi), nije nikakav novi uvid. Prosta usporedba novinarskog izvještavanja o ratnim događajima, poput, recimo, masakra civila na Kapiji u Tuzli ili (ne)obilježavanja Referenduma o nezavisnosti BiH iz 1992. godine, svjedoči o konfliktnosti medijskih figura prošlosti. Komemorativni simbolizam određene epizode ratne povijesti tako se vrednuje pomoću diskursâ afirmacije, negacije, indiferencije/ignoriranja, dominantnih ,osa sjećanja,,, unutar i duž čijih pravaca se suprotstavljene i suparničke naracije uznemirujuće prošlosti međusobno pozicioniraju i suodređuju. Nije teško zaključiti da predstavljanje jednog istog događaja na različite načine - nerijetko sa sasvim oprečnim interpretacijama - rezultira učvršćivanjem i institucionalizacijom međusobno suprotstavljenih prikaza prošlosti u polju javnosti. Odavde obično slijede dva preovladavajuća stajališta. Relativistička pozicija naglašava nemogućnost ili 
teškoću postizanja općeprihvaćenog konsenzusa o ratnoj prošlosti u javnosti, zbog čega se treba „okaniti,, uznemirujuće prošlosti i usmjeriti pogled ka budućnosti. Hegemonijska pozicija, nasuprot njoj, pretpostavlja da su neka razumijevanja ,kontroverzne prošlosti,, ispravnija od drugih, a nakon što se predoče „,nepobitni dokazi,,, potvrđeni pomoću znanosti i sankcionirani putem prava, višesmislenost će iščeznuti, te će u konačnici ostati jedan (jedini) ,pravovjerni,, prikaz povijesti.

Mi, međutim, oba stajališta smatramo problematičnim, zato što zanemaruju i propuštaju ključni uvid, tačku u kojoj se sve tri „ose sjećanja,, ukrštaju i stapaju u jedno: ishodišnu poziciju neodređenosti, zajednički nazivnik cjelokupne javne upotrebe prošlosti u postdejtonskoj BiH. Ono što smatramo ključnim upravo je dispozitiv koji (strateški) projicira, obnavlja i čini mogućim (su)postojanje svih suprotstavljenih vizija povijesti, relativizirajući, zauzvrat, svaku ponaosob. Ili, drugim riječima, osobita temporalna struktura koja, u svojevrsnom modusu aequilibrium indifferentiae, nepremostive razlike u shvaćanjima bh. bliske prošlosti održava u stanju ravnoteže. U nedostatku boljeg termina zovemo je neodređenošću prošlosti, strukturnom koncepcijom vremena u osnovama postdejtonskog poretka koja proizvodi inherentnu manjkavost svake interpretacije povijesti, odnosno, već na razini značenja svaku ,spiralu signifikacije,, pretpostavlja kao problematičan, nepotpun i prije svega neodređen diskurs. Logika u pozadini indeterminacije - logika paradoksa i apsurda - tako u odnosu spram „kontroverzne prošlosti,, osigurava da nijedan akter u ,mnemoničkoj areni,, nije - paradoksalno - ni pobjednik, ali ni gubitnik, što s druge strane znači da iste naracije, simbole i rituale sjećanja svi akteri mogu nastaviti opetovati - in continuo ad absurdum - u polju javnosti.

Mirovni ugovor iz Daytona, naime, konstituirao je $\mathrm{BiH}$ kao sui generis političku zajednicu: inherentno nedovršenu/nesavršenu državu. $\mathrm{Na}$ simboličkoj razini, intencionalnu nedorečenost i manjkavost postdejtonskog projekta državotvorenja možda najbolje izražavaju klasične državničke ikone. Ustav $\mathrm{BiH}$, na primjer, u izvornom obliku napisan je na engleskom jeziku, sačinjen i potpisan izvan $\mathrm{BiH}$, a uz to je i na gotovo misteriozan način ,izgubljen, unutar državnih ustanova. ${ }^{16}$ Himna BiH, nadalje, teško se

16 Originalni bh. (tzv. ,sarajevski,,) primjerak Općeg okvirnog sporazuma za mir, čiji je dio Ustav BiH (Aneks VI), ,izgubljen, , je u institucijama BiH početkom 2008. godine, nakon čega je Ministarstvo vanjskih poslova Francuske, na zahtjev Zastupničkoga doma Parlamenta $\mathrm{BiH}$, dostavilo ovjerenu kopiju Daytonskog sporazuma sa svim aneksima. Ista situacija ponovila se i u Srbiji, jednoj od država potpisnica Sporazuma, koja je također 2008. godine zatražila od Francuske, depozitara Sporazuma, dostavljanje kopije dokumenta, nakon što je utvrđeno da se u državnim institucijama „izgubio,, srbijanski (tzv. „,beogradski,,) primjerak Sporazuma. 
može otpjevati „,patriotski,, budući da muzika nema prateći tekst, čiji sadržaj je višegodišnji politički spor u Parlamentu BiH. Dva entiteta, kao i Distrikt Brčko, od kojih je sastavljena postdejtonska BiH imaju svoje praznike ali ne i država, oko čijeg ,rođendanskog datuma,, u javnosti ne postoji opća suglasnost. Zastava $\mathrm{BiH}$, osim što u ,minimalističkom maniru,, simbolično izražava teritorijalnu cjelovitost i predodžbu $\mathrm{BiH}$, također više govori o projiciranoj „europskoj budućnosti,, na što upućuju zvjezdice i plavo-žute boje, nego što izražava autentična obilježja bh. identiteta itd. Državnonacionalni simbolizam postdejtonske $\mathrm{BiH}$, može se zaključiti, istovremeno - sasvim paradoksalno - afirmira i negira tipične državne ikone (izgubljeni ustav, himna bez teksta, država bez praznika itd.). Postdejtonska $\mathrm{BiH}$ se, zapravo, opire klasičnim kategorijalnim distinkcijama kojima se opisivao univerzum moderne politike (vanjsko/unutrašnje, globalno/lokalno, državanacija/međunarodna zajednica). Rasredištene, ove kvalitete sa Ugovorom iz Daytona stupaju u kompleksne topološke odnose međusobnog preplitanja, uvjetovanja i nerazlučivosti. Nekoliko, sasvim osnovnih, pitanja može to zorno ilustrirati. Šta je, na primjer, osnivački akt, ustav postdejtonske BiH, međunarodni ili nacionalni dokument, proizvod domaćih ili međunarodnih političkih subjekata? Ko je politički subjekt $\mathrm{BiH}$, lokalne (etnonacionalne) političke elite ili predstavnici međunarodne zajednice u BiH? Ko je suveren $\mathrm{BiH}$, bh. građani ili konstitutivni narodi ili vanjski upravitelj? Šta je temeljni politički nacrt bh. stranačkih ideologija, jačanje, izgradnja i integracija ili pak slabljenje, razgradnja i dezintegracija $\mathrm{BiH}$ ? Neodređenost osnovnih atribucija, odnosno prožimanje, uvjetovanje i nerazlučivost prividno oprečnih činitelja, zajednički je nazivnik, lako je uvidjeti, svih pitanja o postdejtonskoj BiH. Otuda su, načelno, pogrešne sve analize koje paradoksna obilježja postdejtonske $\mathrm{BiH}$ iščitavaju kao dokaz bezuspješnosti, nefunkcionalnosti i nemogućnosti $\mathrm{BiH}$ kao države. Isto naravno važi i za njihove obrnute odraze u ogledalu, političke projekte koji djeluju s uvjerenjem da se $\mathrm{BiH}$ kao država može ostvariti kroz dejtonski ustavni okvir. Suprotno ovim pristupima, mi smatramo da kritičko mišljenje počinje onog trenutka kada se ocrtane proturječnosti promisle ne (samo) kao iskazi problematične političke konfiguracije nego kao sam modus vivendi postdejtonske $\mathrm{BiH}$. Načela indistinkcije $\mathrm{i} / \mathrm{ili}$ indeterminacije, imanentne strukturama izuzetka i odnosima simulacije, relevantna su logičko-metodološka načela razumijevanja, primjerena osvjetljavanju složenih političkih konstelacija poput same postdejtonske $\mathrm{BiH}$. Ona su komplementarna, mišljenja smo, novijim interdisciplinarnim pristupima bh. znanstvenika koji postdejtonsku 
$\mathrm{BiH}$ promatraju kao par excellence prostor ispoljavanja suverenih (bio) političkih režima moći i oblika života koje oni produciraju, a koje teoretičari opisuju figurama „golog života,, (Agamben), „ljudskog otpada,, (Bauman) ,multikulturalizma, (Žižek) i sličnim konceptima. ${ }^{17}$

Nerzuk Ćurak tako na više mjesta piše o postdejtonskoj BiH kao „oglednoj zemlji,, (Ćurak, 2002), „državi eksperimentu,, (Ćurak, 2006), testnoj zoni za isprobavanje različitih političkih scenarija, postmodernoj političkoj zajednici koja svoju geopolitičku relevanciju stiče sasvim apsurdno kao ,geopolitička kloaka,", ,poligon za istresanje različitog geopolitičkog trasha, (Ćurak, 2009)..$^{18}$ Slično tvrdi i Jasmina Husanović kada postdejtonsku BiH sagledava kao eksperimentalno polje novih biopolitičkih oblika upravljanja životom i smrću u postkonfliktnim zajednicama. „Bio-kratski,, (inter)nacionalni režimi suverene moći, nisu odgovorni niti jednoj političkoj zajednici nego ,,interesima globalnih i lokalnih, privatnih i državnih elita koje multipliciraju i usavršavaju mehanizme ovladavanja tijelima određene populacije kao proizvodnim sredstvom koje ima nusproizvod, one oblike življenja koji postaju otpad,, (Husanović, 2012: 13).

Budući da između svakog političkog poretka i vremena postoji stanovit odnos (Edkins, 2003), i postdejtonska BiH također pretpostavlja određenu koncepciju temporalnosti, koja podupire njenu političku egzistenciju $\mathrm{u}$ aktuelnom obliku. Koncepcija vremena u osnovi političkog poretka postdejtonske $\mathrm{BiH}$ privilegira dimenzije sadašnjosti i budućnosti, dok prošlost uopće ne pretpostavlja niti kao nužan niti poželjan činilac uspješnog funkcioniranja dejtonske države. Općeprihvatljiv narativ o (zajedničkoj) prošlosti u postdejtonskoj $\mathrm{BiH}$ nije moguće postići, ne zato što sadržaji

17 Vidimo ih u ratu protiv $\mathrm{BiH}$ gdje je razlika između policijskih i kriminalnih struktura, zločinaca i patriota, komšija i neprijatelja, novinara i propagandista, ljudskog i životinjskog, biologije i politike zamagljena i nerazlučiva. Ali, i u postdejtonskoj BiH koja se konstituira u svojevrsnom izvanrednom stanju, u kojem se nacionalne i internacionalne, legalne i ilegalne, legitimne i nelegitimne političke strukture prožimaju i međusobno uvjetuju. Prepoznajemo ih u masovnim grobnicama, ,metaforama za ljudski otpad,,, ali i u životima agregiranim na ,getoizirane prostore,, kakva je sadašnja BiH, kao strategiji uklanjanja i vezivanja za tlo ljudskog otpada, radne snage koja je postala neupotrebljiva i beskorisna iz ugla kapitala/moći (Husanović, 2012: 12-13).

18 U duhu Baudrillarda, Ćurak sasvim tačno uočava simulacijska obilježja političkih odnosa koje pretpostavlja postdejtonska paradigma $\mathrm{BiH}$, koje opisuje atributima kao što su samoreferencijalnost, odsustvo državotvornog sadržaja, oslobođenost svrhe povijesti, prekomjerna proizvodnja prezenta, ispražnjenost bh. (meta)fizičkog prostora bilo kakvim oblicima zajedničkog smisla itd. Tako i piše da je u „ravni zbilje BiH simulacija,, a „u ravni simulacije BiH je zbilja,, (Ćurak, 2005: 9), budući da ovakva tvorevina ima smisla samo u logici simulakruma, gdje se djelo začinje na osnovu svoje reproduktivnosti, indiferentno spram porijekla i svrhe. Kod simulacijskih odnosa, kako je tvrdio Baudrillard, ključna je reproduktivnost samog modela-kôda, koja ne mora biti racionalna (niti ontološka) nego samo operacionalna. 
takve prošlosti ne postoje nego zato što poretku takvo nešto nije potrebno za ustaljeno funkcioniranje. Samo u uvjetima neodređene, to jest, relativizirane i dekonstruirane prošlosti ona može postojati i održavati se u svom sadašnjem obliku, ravnoteži nepremostivih razlika. Otuda se postdejtonska $\mathrm{BiH}$ kao država konstituira uz pretpostavku strukturne indeterminacije prošlosti, što je neophodni uvjet paradoksalnog supostojanja suprotstavljenih prikaza prošlosti u polju novinarstva.

Uz produkciju i institucionalizaciju oprečnih tumačenja ratne povijesti u području javnosti, drugi zajednički imenitelj dominantnih novinarskih diskursa sjećanja su gotovo identične kognitivne matrice i operacije posredstvom kojih se odvija imaginacija uznemirujuće prošlosti. Riječ je o paradoksnom kodificiranju traumatičnog iskustva skupovima signifikacija koji su inducirali upravo ta ista iskustva. Temeljna struktura ovih simboličkih praksi je proizvodnja afektivnih etničkih razlika: svođenje punine ljudskog bića na (isključivo) jedno svojstvo, to jest, reduciranje svih (stvarnih i potencijalnih) dimenzija čovjekovog identiteta na samo jednu veličinu: etničku pripadnost. Ključno „dostignuće, rata upravo je strukturiranje (osmišljavanje) društvene zbilje, odnosno, imenovanje i izlaganje svijeta prošlosti posredstvom etnonacionalnih kategorija. Onih istih politika nominalizacija koje su inducirale traume ratnog nasilja, odnosno, režima predstavljanja koja su sve dimenzije čovjekovog (političkog) identiteta svela na samo jednu dimenziju - nedokučivu, apsolutnu partikularnost, krvno-kulturnu srodnost, sam goli život. Kako razumjeti ove proturječnosti?

U pronalaženju odgovora na ovo pitanje mogu nam pomoći ranije navedeni uvidi o autoritetima posredstvom čijih se iskaza oblikuju prikazi prošlosti u medijskim tekstovima. Klasa biografskih izvora, kao što smo rekli, neumitan je narativni autoritet $\mathrm{u}$ opisu ratnih trauma. Nasuprot njima, klasa stručno-pravnih izvora neosporan je autoritet za objašnjenje događaja nasilja. Ako je prvim svojstvena afektivnost i subjektivnost, onda se za druge vezuje objektivnost. U medijskim tekstovima, posebno izvještajima koji žanrovski teže „objektivnom,, prikazu događaja, tako je evidentna, višemanje eksplicitna, putanja od subjektivnog, afektivnog opisa traumatičnog iskustva, koje iznose žrtve, do hladne, racionalne, objektivne sudske odluke, koja na temelju znanstveno utvrđenih činjeničnih dokaza, „van svake sumnje,, treba da razjasni prirodu zbivanja, žrtve i počinioca, a time na određeni način „deaktivira,,, ,ukroti,,, ,umiri,, i „ohladi,, afektivnost. Obrazac toka vidljiv je u gramatici komemorativnih priča, koje počinju sa stravičnim opisima uznemirujuće prošlosti a završavaju s konstatacijama o sudskim procesima, 
prošlim, trenutnim i budućim, koji su utvrdili, utvrđuju ili nisu još utvrdili činjenice o zlodjelu. Važno je razumjeti konstitutivnu ideološku fantaziju koja se skriva iza ovih trajektorija: vjerovanje u izvanjski stručni autoritet, koji će pomoću znanosti utvrditi, a kroz pravo sankcionirati objektivnu istinu o prošlosti, a time i prevazići primordijalne i tribalne afekte, odnosno, dovesti do procesa pomirenja.

Naime, okosnicu tehnologija kulturaliziranog upravljanja traumom, kako je uočila Jasmina Husanović, čini upravo menadžment afektom, dominantni diskurs (inter)nacionalnih režima moći/znanja/vladanja, koji operira unutar zablude ili vjere u magični legalizam te naučno i birokratsko upravljanje projektom pod zajedničkim nazivnikom izgradnje mira i društvenog pomirenja, praznih označitelja tranzicijske pravde (Husanović, 2010). Terapeutski pristup koji podrazumijeva menadžment afektom u biti predstavlja postpolitičko razumijevanje upravljanja traumom. Naime, ono traumatično iskustvo odvaja od političke sfere i izmješta u polje znanosti, gdje se abjektna tijela suverenih politika, poput krvi, kosti i DNK uzoraka nestalih osoba, matematiziraju i svode na bar kodove $\mathrm{u}$ administrativnom hipertehnologiziranom okruženju koje opslužuje bioinformatiku, forenziku, genomiku i slične znanstvene discipline. Kao što naglašava Husanović, upitna pretpostavka na kojoj se temelji cjelokupna paradigma „terapeutske pravde,, je uvjerenje da se traumom na ličnom i kolektivnom planu može ovladati. Ovakav pristup stoga ne vodi emancipativnim praksama niti kritičkim kulturama sjećanja nego normalizaciji, mitologizaciji i iščezavanju traumatičnog iskustva iz područja javnosti i/ili prepuštanju polju religije (ibidem). Drugo, ono predstavlja pogrešno tumačenje situacije jer je ,stvaranje afektivnih veza i podela obično cilj ratnih zločina, a ne uzrok,, (Wastell prema Husanović, 2012: 15). Ono, zapravo, isključuje odgovornost zajednice, one „koji su zažmurili, koji nisu intervenisali, oni koji nisu znali da nađu Jugoslaviju na mapi, ili ih nije bilo briga za to, , (ibidem). ${ }^{19} \mathrm{I}$, možda najvažnije, terapeutsko upravljanje traumom ,perpetuira iste politike terora i rasističke identifikacije zasnovane na krvi

19 Koncept kolektivne odgovornosti u postjugoslavenskom kontekstu s pozicija liberalizma najdosljednije je razradio Nenad Dimitirijević. Kolektivna odgovornost spram masovnog zločina treba se sagledati, smatra Dimitrijević, u odnosu na prirodu režima koji čini masovna zlodjela i prirodu odnosa između režima i njegovih podanika. Prema njemu „masovni zločin analitički je obeležen sledećim svojstvima: ideološkim opravdanjem, pogotovo načinom na koji ideologija određuje i izdvaja metu mržnje; brojem žrtava; ulogom režima u zločinačkim aktivnostima; brojem počinilaca i saradnika; uverenjima, stavovima i ponašanjem 'običnih ljudi' (Dimitrijević, 2011: 46). Unutar masovnog zločina dalje se mogu razlikovati, prema Dimitrijeviću, dvije podvrste: režimski i kolektivni zločini. Potonje oblike kolektivnog zločina, čija su glavna obilježja ,populistička integracija, koja uključuje visok stepen ideološke i praktične saglasnosti oko zločina,, (ibidem, 54), Dimitrijević prepoznaje u uznemirujućoj prošlosti nedavne ratne povijesti. 
i kosti etnonacionalnog srodstva (...) Vidimo to čak i u radu Međunarodne komisije za nestale osobe čiji je proizvod to da su nestale osobe identifikacijom ponovo reinsertovane $u$ poretke države, etnonacije i religije $u$ ime pravde $i$ budućnosti koju nudi režim terapeutskog vladanja kroz tranzicijsku pravdu, (Husanović, 2012: 14). Menadžment afektom, kratko kazano, mjesto je na kojem se susreću etnonacionalne i neoliberalne kulture trauma i identitarne politike u postdejtonskoj $\mathrm{BiH}$.

Doprinos medija unapređenju kritičkog pristupa razumijevanja tema ratne povijesti ovisi prvenstveno od kapaciteta bh. novinarstva da problematizira ove dominante okvire spoznavanja i imenovanja svijeta prošlosti koje pretpostavlja postdejtonski poredak. Takve prakse nisu oprečne nego naprotiv sukladne temeljnoj aktivnosti-svrsi novinarske profesije: zadatku artikuliranja javnog interesa, koji se ne može omeđiti partikularnim, etnonacionalnim i/ ili neoliberalnim, kulturno-srodničkim i/ili spektakularno-konzumerističkim identitetima. Najmanje dva uvjeta nužna su za postojanje i održavanje tako usmjerene djelatnosti: strukturiranje polja novinarstva na načelima autonomnosti, a novinarskih habitusa na etičkim načelima žurnalističke profesije. Ispunjavanje ovih uvjeta nije samo odgovornost medijskih organizacija nego i cjelokupne zajednice, čije preferencije u pogledu korištenja medija uvijek značajno utječu na preovladavajuće novinarske sadržaje, prakse i institucije.

\section{Zahvale}

Autor se iskreno zahvaljuje profesorici dr. sc. Jelenki Voćkić-Avdagić i profesorici dr. sc. Vedadi Baraković na konstruktivnim komentarima, sugestijama i savjetima, koji su skupno doprinijeli boljem razumijevanju, promišljanju i istraživanju tretmana prošlosti u informativnoj djelatnosti. 


\section{MEDIA-CONSTRUCTED COLLECTIVE MEMORIES: HISTORY TREATMENT IN JOURNALISM WITH FOCUS ON POST-DAYTON BOSNIA AND HERZEGOVINA}

\section{- Abstract -}

In this work we critically consider the practice of treating history in the area of journalism respectively media as an distinctive institutional arena of contemporary communities for establishment, maintenance and transformation of common frameworks of understanding and commemorating of certain episodes from the past. We intent to offer plausible explanations regarding the relations between ,culture of remembrances” and „culture of reporting". Article suggests how to approach the often misunderstood history in informative activity, which in its field of action and by definition does not have the dimension of history but the dimension of social situation of contemporariness. We also form the key operations and strategies used in shaping the repertoire of journalistic reports on the past. Described practices we study on the example of post-Dayton BiH, analysing media treatment of conflict areas during the recent war history. Legitimisation of ethnicnational visions of the past through the discourse of reporting has been recognised as the dominant way of working in the "media memory field". Two key paradoxes of these practices are highlighted: coexistence of opposite discourses of commemoration and codification of abjection experiences by the same group of significations which have initially inducted the war traumas. We point out at least two conditions which facilitate these paradoxes: ambiguity of the past, conception of time which is assumed by post-Dayton Bosnia and Herzegovina as an inherently uncompleted/imperfect country and technologies of culturised steering of trauma, which is being used by regimes of , therapeutic/transitional justice” to cope with disturbing history in postconflict communities.

Keywords: field of journalism, discourse of reporting, culture of remembrance, traumatic memories, post-Dayton $\mathrm{BiH}$. 


\section{Literatura}

- Allan, S. (2004): News Culture, Buckingham: Open University Press.

- Assmann, A. (2011): Duga senka prošlosti: kultura sećanja i politika povesti, Beograd: XX vek.

- Assmann, J. (2008): Kulturno pamćenje (pismo, sjećanje i politički identitet $u$ ranim visokim kulturama), Zenica-Tuzla: Vrijeme \& Nam.

- Bauman, Z. (2009): Fluidni život, Novi Sad: Mediterran Publishing.

- Carey, J. W. (2009): Communication as Culture: Essays on Media and Society, New York: Routledge.

- Connerton, P. (1989): How Societies Remember, Cambridge-New York: Cambridge University Press.

- Connerton, P. (2008): 'Seven Types of Forgetting', Memory studies, vol. 1, no.1.

- Ćurak, N. (2002): Geopolitika kao sudbina (postmodernistički ogled o perifernoj zemlji), Sarajevo: FPN.

- Ćurak, N. (2005): „Kontroverze i paradoksi kvazidemokratskog okvira,,, Zeničke Sveske, 9-12.

- Ćurak, N. (2006): Obnova bosanskih utopija (politička filozofija, politologija $i$ sociologija postdejtonske BiH), Sarajevo-Zagreb: Synopsis.

- Ćurak, N. (2009): „Je li Bosna i Hercegovina važna zemlja? Geopolitičke dileme i imperativ državnosti,,, online magazin Puls Demokratije, dostupno na http://arhiva.pulsdemokratije.net/index. php?id $=1404 \& \mathrm{l}=$ bs.

- Dimitrijević, N. (2001): Dužnost da se odgovori. Masovni zločin, poricanje i kolektivna odgovornost, Beograd: Fabrika knjiga.

- Dudai, Y. (2002): Memory From A to Z. Keywords, Concepts, and Beyond, Oxford-

- -New York: Oxford University Press.

- Edgerton, G. R. i Rollins, P. C. /eds./ (2001): Television Histories: Shaping Collective Memory in the Media Age, Lexington: The University Press of Kentucky.

- Edkins, J. (2003): Trauma and the Memory of Politics, Cambridge: Cambridge University Press.

- Edy, J. (1999): „Journalistic Uses of Collective Memory,„, Journal of Communication, vol. 49, no. 2.

- Edy, J. A. (2006): Troubled Past: News and the Collective Memory of Social Unrest, Philadelphia: Template University Press. 
- Erjavec, K. (2011): „Slučaj Dobrovljačka: analiza srpske i bosanskohercegovačke štampe,,, u Džihana, A. et al. /ured./: Mediji i nacionalne ideologije: analiza izvještavanja o suđenjima za ratne zločine, Mediacentar Sarajevo.

- Frosh, P, \& Pinchevski, A. /eds./ (2009): Media Witnessing: Testimony in the Age of Mass Communication, Houndmills: Palgrave Macmillan.

- Garde-Hansen, J., Hoskins, A. \& Reading, A. (2009): Save As... Digital Memories, Basingstoke-New York: Palgrave Macmillan.

- Hansen, M. (2004): New Philospohy for New Media, Cambridge, MA-London: MIT Press.

- Hoskins, A. (2008): „Collective Memory and Media,, u Donsbach, W. (eds.) The International Encyclopedia of Communication, Malden-Oxford-Carlton: Blackwell Publishing.

- Hoskins, A. (2013): „The End of Decay Time,,, Memory Studies, 6(4).

- Husanović, J. (2009): Između traume, imaginacije i nade. Kritički ogledi o kulturnoj produkciji i emancipativnoj politici, Beograd: Fabrika knjiga.

- Husanović, J. (2010): „Ka emancipativnoj politici svjedočenja: politika nestalih kao vladanje traumom kroz kodifikaciju/ matematizaciju/depolitizaciju na razmeđima (inter)nacionalnih režima 'terapeutske/tranzicione pravde',", transkript javnog predavanja u sklopu Oktobarskog salona u Beogradu 2008. godine, novine Matemi reasocijacije, Grupa Spomenik: Beograd.

- Husanović, J. (2012): „Kultura traume i identitarna politika u BiH: kritika ideologije pomirenja,,, Diskursi - društvo, religija, kultura, godina II, broj 3.

- Kitch, C. (2002): „Anniversary Journalism, Collective Memory, and the Cultural Authority to Tell the Story of American Past,,, Journal of Popular Culture, 36 (1).

- Kitch, C. (2002): Pages from the Past: History \& Memory in American Magazines, Chapel Hill: The University of North Carolina Press.

- Kitch, C. (2008): „Placing Journalism Inside Memory and Memory Studies,, Memory Studies, (1).

- Kuljić, T. (2006): Kultura sećanja: teorijska objašnjenja upotrebe prošlosti, Beograd: Čigoja štampa. 
- Leggewie, C. (2011): „Seven Circles of European Memory,", u Meusburger, P., Heffernan, M. \& Wunder, E. /eds./: Cultural Memories: The Geographical Point of View, Heidelberg-LondonNew York: Springer.

- Lim, J. (2010): „Victimhood Nationalism in Contested Memories: National Mourning and Global Accountability,,, u Assmann, A. \& Conard, S. /ed./ (2010): Memory in the Global Age (Discourse, Practices and Trajectories), Basingstoke-New York: Palgrave Macmillian.

- Lovink, G. (2011): Networks Without a Cause. A Critique of Social Media, Polity Press: Cambridge-Malden.

- Mahmutović, M. (2012): „Novosti o prošlosti: joker za (ne)sigurnu budućnost - prilozi za izučavanje predstavljanja ratne prošlosti u bh. dnevnim novinama,,, Medijski dijalozi - časopis za istraživanje medija i društva, godina V, broj 13-14.

- Mayer-Schönberger, V. (2009): Delete: The Virtue of Forgetting in the Digital Age, Princeton-Oxford: Princeton University Press.

- Misztal, B.A. (2003): Theories of Social Remembering, Philadelphia: Open University Press.

- Neiger, M., Meyers, O.\& Zandberg, E. (2011): On Media Memory: Collective Memory in a New Media Age, Basingstoke-New York: Palgrave Macmillian.

- Nora, P. (2007): „Između sjećanja i povijesti,,, Diskrepancija, svezak 8 , broj 12.

- Olick, J. K., Vinitzky-Seroussi, V. \& Levy, D. (eds.) (2008): The Collective Memory Reader, Oxford: Oxford University Press.

- Phillips, K. R. (ed.) (2004): Framing Public Memory, Tuscaloosa: University of Alabama Press.

- Reading, A. (2011): „Memory and Digital Media: Six Dynamics of the Globital Memory Field,,, u Neiger, M., Meyers, O. \& Zandberg, E. (eds.) On Media Memory: Collective Memory in a New Media Age, Basingstoke-New York: Palgrave Macmillian.

- Schudson, M. (1992): Watergate in American Memory: How We Remember, Foreget and Reconstruct the Past, New York: Basic Books.

- Schudson, M. (2003): The Sociology of News, New York-London: Norton \& Company.

- Voćkić-Avdagić, J. (2002): Suvremene komunikacija (ne/sigurna igra svijeta), Sarajevo: FPN. 
- Wertsch, J. (2004): Voices of Collective Remembering, CambridgeNew York: Cambridge University Press.

- Zandberg, E. (2010): „The Right To Tell The (Right) Story: Journalism, Authority and Memory,,, Media Culture Society, 32 (1).

- Zelizer, B. (1992): 'Covering the Body': The Kennedy Assassination, the Media and the Shaping of Collective Memory, Chicago: University of Chicago Press.

- Zelizer, B. (2008): „Why memory’s work on journalism does not reflect journalism's work on memory,, Memory Studies, Vol 1(1).

- Zelizer, B. (2011): „Canibalizing Memory in the Global Flow of News,,, u Neiger, Motti, Meyers, Oren \& Zandberg, Eyal /eds./: On Media Memory: Collective Memory in a New Media Age, Basingstoke-New York: Palgrave Macmillian. 
Branislava Knežićl,

Maja Savić2

UDK: $374.7-058.5(497.11)$

$343.81(497.11)$

\section{OBRAZOVANJE U ZATVORU: OD PRAVA DO REALIZACIJE ${ }^{3}$}

\section{- Sažetak -}

Porast broja povratnika, prenatrpanost zatvora $i$ loši uslovi u njima ne ulivaju nadu da se društvo na najbolji način suočava sa problemima kriminaliteta. Od osamdesetih godina prošlog veka, u većini zapadnih zemalja $i$ kod nas, na udaru kritike našao se koncept resocijalizacije jer se smatra da nije doveo do smanjenja ukupnog kriminaliteta i recidivizma. Problem sa kojim se društva suočavaju je kako u zatvorskoj sredini pripremiti osuđenika da se uspešno integriše u društvenu zajednicu po izlasku iz zatvora. Veoma važnu ulogu u realizaciji ovog cilja može imati obrazovanje. U članku ćemo se baviti različitim aspektima obrazovanja u zatvoru: kako ga država propisuje $i$ kako vidi njegovu svrhu, kakvo je aktuelno stanje u realizaciji prava na obrazovanje u nekim zemljama sveta $i$ kod nas, koje su prepreke u realizaciji obrazovanja u zatvorima. Jedan od glavnih preduslova za implementaciju $i$ uspeh obrazovnih programa u zatvoru jeste i motivacija samih osudenika da se uključe u njih. Prikazaćemo deo empirijskog istraživanja sprovedenog na prigodnom uzorku iz dva KPZ (Požarevac i Sremska Mitrovica) o motivaciji osuđenika za obrazovanjem i obrazovnim potrebama.

1 Dr. Branislava Knežić je vanredni profesor na Odeljenju za pedagogiju i andragogiju Filozofskog fakulteta Univerziteta u Beogradu, naučni savetnik Instituta za kriminološka i sociološka istraživanja u Beogradu.

2 Dr. Maja Savić je docent na Filološkom fakultetu Univerziteta u Beogradu, naučni saradnik Instituta za kriminološka i sociološka istraživanja u Beogradu.

3 Članak je uz odobrenje autorica, preuzet iz časopisa „Andragoške studije” I/2013 i predstavlja rezultat rada na projektu „Kriminal u Srbiji:fenomenologija, rizici i mogućnosti socijalne intervencije" (br. 47011) koji finansira Ministarstvo prosvete, nauke i tehnološkog razvoja Republike Srbije (2011-2014). 
Ključne reči: obrazovanje, zatvorenici, recidivizam, resocijalizacija, zatvorska sredina.

Uprkos manjkavostima izvora podataka i metodološkim teškoćama u njihovom prikupljanju u različitim zemljama, postojeći podaci pokazuju da je opšti trend u svetu uvećanje zatvorske populacije. Stopa zatvaranja porasla je u 78\% zemalja sveta - 71\% zemalja u Africi, $82 \%$ u Americi, $80 \%$ u Aziji, 74\% u Evropi i 80\% u Okeaniji (Walmsley, 2012). U Evropskoj uniji je u periodu 1995-2009. broj osuđenika porastao za 24\% (European Comission, 2010), a u Srbiji u periodu 2005-2010. za 30\% (Helsinški odbor za ljudska prava u Srbiji, 2010). Ovakvo značajno povećanje zatvorske populacije stavlja države i društva pred ozbiljne izazove, s jedne strane finansijske jer predstavlja dodatno opterećenje državnog budžeta, a s druge strane društvene, jer raste broj ljudi koje je potrebno na neki način resocijalizovati i integrisati na funkcionalan način u društvo.

Pitanje je da li zatvori i tretmani onakvi kakvi su mogu ispuniti svrhu kažnjavanja kako je zakon određuje: „Svrha izvršenja kazne zatvora je da osuđeni tokom izvršenja kazne, primenom odgovarajućih programa postupanja, usvoji društveno prihvatljive vrednosti u cilju lakšeg uključivanja u uslove života posle izvršenja kazne kako ubuduće ne bi činio krivično delo,, (čl. 31. Izmene ZIKS RS). Ne samo normativna akta nego i stručna literatura nije jednoglasna i nije lišena pojmovne zbrke u brojnim pokušajima definisanja svrhe izvršenja zatvorske kazne. Insistiranje na preciznosti određenja termina: resocijalizacija, prevaspitavanje, reintegracija, popravljanje, osposobljavanje za istraživače u ovoj oblasti je manji problem od načina kako se taj proces organizuje, ko ga sprovodi i kojim metodama i sadržajima. Prema našem uverenju pravo pitanje bi bilo da li su aktivnosti usklađene sa potrebama i mogućnostima cilja kažnjavanja i na koji način se obrazovanje uklapa u njih.

Poznato je da zatvorski tretman u većini zemalja počiva na radnim obavezama i obrazovnim programima ${ }^{4}$. Evropska zatvorska pravila ${ }^{5}$ posvećena obrazovanju zatvorenika sadrže 7 članova od kojih izdvajamo: 28.1 „Svaki zatvor treba da nastoji da svim zatvorenicima omogući pristup obrazovnim programima koji su što je moguće sveobuhvatniji i koji zadovoljavaju njihove individualne potrebe, istovremeno vodeći računa o njihovim težnjama,,, 28.2 „Prioritet imaju zatvorenici koji su nepismeni ili oni koji nemaju osnovno ili

4 U okviru Obrazovnog programa Sokrat Evropske unije pokrenuta je šira evropska mreža za obrazovanje u zatvoru kako bi proširila aktivnosti.

5 Preporuka Rec (2006) 2 Komiteta ministara država članica u vezi sa evropskim zatvorskim pravilima, koju je usvojio Komitet ministara 11. januara 2006. na 952. sednici zamenika ministara. 
vokaciono obrazovanje,, i 28.3 „Posebna pažnja poklanja se obrazovanju mlađih zatvorenika i zatvorenika s posebnim potrebama,..

Naše zakonodavstvo takođe propisuje pravo na obrazovanje u zatvoru, ZIKS čl. 110: „Osuđeni ima pravo na osnovno i srednje obrazovanje, koje se shodno opštim propisima organizuje u zavodu. Zavod organizuje i druge vidove obrazovanja,,

Zbog potreba usklađivanja sa evropskim pravnim standardima i preporukama Saveta Evrope unete su promene i donet je zakon o izmenama i dopunama Zakona o izvršenju krivičnih sankcija (Sl. glasnik RS, br.72/09). Zakonske odredbe pružaju dovoljan okvir za osposobljavanje osuđenih u cilju uspešne integracije u društvo i život na slobodi, ali neophodan je suštinski, a ne deklarativni stav društva prema tretmanu u zatvorima.

Bez obzira na to koliko je zatvorska sredina veštački ambijent opasan zidovima i raznovrsnim ograničenjima proizvešće manje deprivacije i štetne posledice po osuđenike, ako vreme provedeno u zatvoru bude smislenije od „treniranja strogoće,,, prebrojavanja, cinkarenja, obavljanja raznih besciljnih zadataka, ispraznog slobodnog vremena i sl. Proces i aktivnost koja može da bude važna poluga promene na individualnom (ličnost, ponašanje, kvalitet života osuđenika) i društvenom planu je obrazovanje, ali da bi ono zaista postalo faktor promene potrebno je da njegov značaj i potencijal nedvosmisleno prepoznaju i država (ne samo formalno) i sami osuđenici.

Društva daleko bogatija od našeg imaju problem sa finansiranjem edukativnih programa u zatvorima. Upravo je smanjenje finansiranja ovakvih programa u Americi, navelo istraživače da intenzivnije prate efekte ranije postojećih obrazovnih programa na recidivizam i uspešnost resocijalizacije, kako bi uverili finansijere da je investicija u obrazovanje dugoročno manji trošak za državu. Smanjenje recidivizma pre svega znači smanjenje kriminala, viktimizacije, ali i smanjenje troškova hapšenja, suđenja i zatvorskog života za povratnike.

U SAD i nekim od zemalja EU gde postoji višedecenijska praksa sprovođenja edukativnih programa u zatvorima, rađena su istraživanja koja su pratila efekte zatvorskog obrazovanja na smanjenje recidivizma i uspešniju resocijalizaciju osuđenih lica. Istraživanja su pokazala da su zatvorenici koji pohađaju edukativne programe manje skloni da se vrate u zatvor, tj. da obrazovanje u zatvoru može da utiče na smanjenje recidivizma (Harer, 1994, 1995; Cecil et al., 2000; Hull et al, 2000; Steurer \& Smith, 2003; Vacca, 2004; MacKenzie, 2006). Pokazano je da se smanjuje i nivo nasilničkog ponašanja (Vacca, 2004), kao i broj disciplinskih problema osoba koje učestvuju u 
zatvorskim edukativnim programima (Kling, 2006). Bozos i Hausman (Bozos \& Hausman, 2004) navode da za zatvorenike, koji su prošli neki vid edukacije u zatvoru, postoji 10-20\% manja verovatnoća da će se ponovo vratiti u zatvor u odnosu na one koji nisu učestvovali u edukaciji, dok se u studiji Steurera i Smita (Steurer \& Smith, 2003) navodi da je recidivizam kod osuđenika koji su učestvovali u edukativnim programima za $29 \%$ manji nego kod onih koji nisu. Neki istraživači (Gehring, 2000; Lewis, 2006; Wade, 2007, prema Gaes, 2008) ističu da dobijeni efekti obrazovanja na recidivizam zavise od načina na koji se on meri, od tipova edukativnih programa čiji se efekti prate, kao i od izbora dobrih mera tih programa.

Uprkos donekle skromnijim efektima obrazovanja na recidivizam u odnosu na uložena očekivanja, njegova uloga za pojedince u zatvoru i za društvo u celini ne sme se potceniti.

Države imaju različiti pristup realizaciji obrazovanja u zatvorima. U Francuskoj su obrazovanjem obuhvaćeni samo osuđenici koji su zainteresovani. U Italiji postoji niz mera koje stimulišu srednje i visoko obrazovanje; obrazovne aktivnosti zasnovane su na dobrovoljnom učešću osuđenika, ali onaj koji je aktivno učestvovao u programu reedukacije ima priliku da bude ranije pušten iz zatvora. U Nemačkoj se u okviru socijalne službe u zatvorima ostvaruju ciljevi tretmana u procesu korekcije osuđenikovog ponašanja i služba ima visok stepen samostalnosti i uživa veliki ugled. i u Austriji obrazovanje i profesionalno osposobljavanje zauzima vidno mesto u tretmanu osuđenih lica (školovanje za stručnog radnika, pohađanje stručnih kurseva, nastavak školovanja van zatvora, dopisni kursevi, nastava za učenike, kao i drugi vidovi obrazovanja osuđenika). U poslednje vreme organizuju se razni kursevi za rad na kompjuterima i te diplome su priznate u celoj EU. U zatvorima u Holandiji primenjuju se različiti oblici tretmana, među njima i obrazovanje što zavisi od kategorije zatvorenika i njihovih karakteristika. U ruskim korektivnim ustanovama zatvorenici mogu da ostvare svoje pravo na opšte osnovno i stručno obrazovanje, a omogućeno im je učenje na daljinu i dopisni kursevi. U Hrvatskoj je obrazovanje jedan od bitnijih vidova tretmana iako se poslednjih godina sve manji broj osuđenika odlučuje za nastavak obrazovanja (Stevanović, 2012). Obrazovanje i stručno osposobljavanje u švedskim zatvorima je prilično razvijeno i prati savremene tendencije koje se kreću u pravcu iznalaženja novih oblika i metoda u radu sa zatvorenicima. Važna karakteristika obrazovanja u švedskim zatvorima jeste da je ono sastavni deo redovnog obrazovanja odraslih, što omogućava zatvorenicima da nastave započetu edukaciju po izlasku iz zatvora i da sa 
diplomom stečenom u zatvoru budu konkurentni prilikom traženja posla. Ključno sredstvo u obrazovnim aktivnostima danas je kompjuterizovana platforma pod nazivom Netcentar koji omogućava svakom zatvoreniku da na osnovu svojih planova i ciljeva bira kurseve koji mu odgovaraju (Kosmidou, 2011). To znači da putem ove platforme zatvorenik može da prati i polaže kurseve koji nisu u ponudi obrazovnih programa u zatvoru u kojem je smešten, ali da može da dobije obrazovnu podršku od lokalnih nastavnika i predavača ukoliko mu je potrebna. Ovakvo studiranje povećava dostupnost obrazovanja i omogućava individualizovaniji pristup obrazovanju. Važno je istaći da su ciljevi obrazovanja usmereni na razvijanje kompetenci zatvorenika, pomoć i pripremu za nastavak školovanja nakon zatvora ili dobijanje posla, ali i na razvijanje neformalnih kompetenci kao što su preuzimanje odgovornosti, učešće u timskom radu i funkcionisanje u grupi, koje im pomažu da zadrže posao i utiču na poboljšanje kvaliteta života (Kosmidou, 2011).

Pored toga što edukativni programi omogućavaju sticanje konkretnih znanja i veština koje osposobljavaju ljude za zapošljavanje po izlasku iz zatvora, smatra se da im oni omogućavaju i sticanje nekih novih socijalnih veština i usvajanje prosocijalnih normi važnih za reintegraciju u društvo. Ripli (Ripley, 1993) navodi da recidivizam opada upravo kada su edukativni programi kreirani tako da razvijaju socijalne veštine, podstiču umetničko izražavanje i usvajanje tehnika i strategija za regulisanje vlastitih emocija. Ovaj autor takođe ističe važnost moralnog obrazovanja i razvijanja kritičkog mišljenja i rešavanja problema u edukativnim programima. Učestvujući u ovakvim programima zatvorenici na produktivan način koriste vreme provedeno u zatvoru, a usvajanje novih veština doprinosi njihovom osećanju samopoštovanja i postignuća.

Uspešan obrazovni proces je kompleksan, jer zahteva kontinuitet i ulaganje i ljudskih i materijalnih resursa. S jedne strane postoji zahtev da se taj proces individualizuje i prilagodi potrebama i mogućnostima zatvorenika, a s druge strane da se realizuje u okolnostima povećanog nadzora i ograničenog pristupa resursima (kompjuteri, Internet, biblioteke, materijal za rad). Ova dva zahteva su često u suprotnosti što može dovesti do prepreka i teškoća u realizaciji obrazovnih programa.

Prepreke u realizaciji obrazovanja u zatvoru mogu poticati od samih zatvorenika ili od okolnosti u kojima se realizuje ili institucije koja ga realizuje, pa tako razlikujemo:

- Dispozicione prepreke koje su vezane za samog zatvorenika i posledica su njegovih iskustava za vreme ili posle izdržavanja kazne: 
problematično detinjstvo, neuspeh u školi, nisko samopouzdanje, zloupotreba droge i alkohola, problemi u komunikaciji, učenju ili mentalnom zdravlju).

- Institucionalne i situacione prepreke koje ne zavise od zatvorenika, a u koje spadaju: premeštanje iz jednog zatvora u drugi, odsustvo biblioteka, odsustvo ili oduzimanje pisanog edukativnog materijala, dugo čekanje na mogućnost da započnu kurs, ograničena mogućnost ili potpuno odsustvo mogućnosti da se obuče za rad na računaru; nizak kvalitet obuke; suviše bazičan, neodgovarajući i irelevantan sadržaj obuke, neosetljivost na posebne potrebe onih koji uče, uskraćivanje edukativnih ,privilegija,, kao kaznena mera, nedostatak novca za finansiranje visokog obrazovanja, uskraćivanje prava na obrazovanje u zavisnosti od mesta izdržavanja kazne, dužine kazne i sigurnosne kategorije (UN Human Rights Council, 2009; GHK, 2011).

Jedan od glavnih preduslova zaimplementacijui uspeh obrazovnih programa u zatvoru jeste motivacija samih osuđenika da se uključe u njih. Učešće, motivi i potrebe odraslih za obrazovanjem predmet su mnogih istraživanja i rasprava u naukama koje se bave obrazovanjem odraslih. Navodimo rezultate Bošijea (Boshier, 1985), autora jednog od najpoznatijih radova u andragoškoj literaturi o razlozima participacije odraslih u obrazovanju. Autor ističe da odrasli učestvuju u obrazovnim delatnostima iz sledećih razloga:

- potrebe za socijalnim kontaktom,

- potrebe za socijalnom stimulacijom,

- potrebe za profesionalnim napredovanjem,

- potrebe služenja zajednici,

- potrebe zbog spoljnih očekivanja,

- kognitivnih interesa.

Moglo bi se konstatovati da se odrastao čovek odlučuje za proces obrazovanja iz tri razloga: da bi zadovoljio društvenu sredinu, zadovoljio sebe i dobio poštovanje od drugih. Drugim rečima, odrastao čovek uči da bi znao: raditi, živeti zajedno s drugima i da bi „znao”. Ako se na trenutak zaborave specifični uslovi zatvora kao obrazovne sredine može se reći da i osuđenici imaju iste želje i potrebe za obrazovanjem.

Specifičnost obrazovanja odraslih, za razliku od dece, ogleda se u tome što biraju i sami odlučuju o tome šta žele da uče, u zavisnosti od toga kako vide sebe i da li žele da uče od drugih odraslih. U skladu sa tim, obrazovanje u zatvoru ne počiva toliko na autoritetu koliko na pristanku koji je jako teško 
ostvariti u prinudnom i autoritarnom okruženju kakav je zatvor. Sofer (Soferr, 2006) smatra da su osuđenici ljudi sa bogatim životnim iskustvom koje za njih - iako problematično i različito od iskustva običnih ljudi - predstavlja znanje o svetu oko njih. Opremljeni ovim znanjem često su skloni da odbijaju nova znanja i opiru se pokušajima da ih drugi uvere u suprotno. Prema Soferu pravi izazov za one koji se bave obrazovanjem u zatvoru, pored realizacije obrazovnih programa, je i uvođenje novih znanja, ali na takav način da podstiču želju za promenom i razvojem celokupne ličnosti.

O motivima uključivanja zatvorenika u obrazovne programe govori nam istraživanje Petre Mekginis (Petra MacGuinness, prema Wilson, Reuss, 2000) sprovedeno u muškom zatvoru Whitemoor u Velikoj Britaniji, u okviru obrazovnog odeljenja koje nudi programe od osnovnih veština do univerzitetskog nivoa (Open University studies). Na osnovu podataka koje je prikupila putem upitnika i polustrukturisanih intervjua Mekginisova izdvaja četiri grupe motiva:

1. Da nadoknade ono što su propustili u prvobitnom obrazovanju $(53,6 \%)$ - pošto su mnogi od zatvorenika slične dobi i sličnog socijalnog porekla lakše prihvataju pokušaj da nastave formalno obrazovanje nego što bi to bilo van zatvora;

2. Da bi se zanimali nečim, razbijanje dosade (21\%);

3. Da bi povećali mogućnost za zapošljavanje (13\%);

4. Da bi preživeli zatvor i ispunili vreme.

Ovi nalazi su zanimljivi jer nam govore da su osuđenici svesni društvenog vrednovanja obrazovanja i da je to i najjači motiv za uključivanje u njega.

\section{Obrazovanje u zatvorima u Srbiji}

Pokušaćemo ukratko da damo pregled stanja obrazovanja u zatvorima u Srbiji. Obrazovanje, obuka, kvalifikacija, prekvalifikacija i rad imaju, bar zakonski, bitnu ulogu u tretmanu izvršenja krivičnih sankcija u Srbiji. Međutim, u realizaciji obrazovnih programa zatvorske uprave i osoblje suočavaju se sa brojnim problemima i izazovima jer su prostorni, kadrovski i materijalni uslovi u zatvorima nezadovoljavajući. Zatvori su popunjeni daleko preko svojih kapaciteta, nedostaju materijalna sredstava za modernizaciju i pokretanje proizvodnje, za nabavku opreme i materijala, nedovoljno je sredstava za angažovanje nastavnika, nedostaju pojedini profili stručnjaka za obuku, ugašeno je obrazovanje koje je postojalo do pre dvadesetak godina, jak je uticaj neformalnih grupa u zatvoru, niska je motivisanost osuđenika, 
ali i osoblja za adekvatniju obuku, obrazovanje i organizovanje raznovrsnih tečajeva, predavanja, razgovora, tribina i sl. Prisutno je i potcenjivanje uticaja određenih oblika i vrsta tretmana, a ponekad i stav da samo represija može „slomiti,, počinioce krivičnih dela.

Do kraja osamdesetih godina prošlog veka u zatvorima u Srbiji obrazovanju se pridavao daleko veći značaj nego danas. Kazneno popravni zavodi u Nišu, Požarevcu i Sremskoj Mitrovici imali su obrazovne centre - škole za osnovno i srednje obrazovanje odraslih osuđenika. Škole su bile povezane sa odgovarajućim školama u gradu čime je zadovoljena zakonska obaveza da se iz diploma ne vidi da je osuđenik završio školu u toku izdržavanja kazne. Za vreme postojanja tih centara godišnje je upisivano više stotina osuđenika koji su završavali osnovno i srednje obrazovanje. Nakon toga nastaje sve manje interesovanje za obrazovanje čemu je prethodila sumnja u moć obrazovanja kao oblika tretmana u resocijalizaciji osuđenih i nezainteresovanost uprava zavoda za organizovanjem obrazovanja. Krajem dvadesetog veka u našim KPZ-ima opštim i stručnim obrazovanjem bilo je obuhvaćena oko trećina osuđenika u muškim zatvorima, a gotovo polovina ispitanih je izjavila da bi rado učestvovala u različitim kursevima, tečajevima i predavanjima. Žene ni u tom periodu, zbog malog broja, nisu bile obuhvaćene obrazovanjem iako ih je skoro 40\% bilo nepismeno (Knežić, 2001).

Pravilnikom o organizaciji i sistematizaciji radnih mesta u Upravi za izvršenje zavodskih sankcija (UIZS) iz 2006. godine postojeće škole u KPZ su postale odseci u Službi za prevaspitanje, najčešće sa jednim referentom za organizaciju kulturno-obrazovnih aktivnosti. Ovaj podatak dovoljno govori o tome kako naše društvo vidi ulogu i značaj obrazovanja kao faktora osposobljavanja osuđenih lica za integraciju u zajednicu po izdržanoj zatvorskoj kazni. Učešće osuđenika u edukativnim programima u KPZ-ima u Srbiji se u poslednjih dvadesetak godina kreće od 1-3\%. U KPZ Sremska Mitrovica postoji mogućnost osnovnoškolskog i srednjoškolskog obrazovanja, ali osuđenici u veoma malom broju koriste ove mogućnosti. Prema podacima Helsinškog odbora za ljudska prava (2010) preko 200 osuđenika (od ukupno 1764) ima potrebu za osnovnoškolskim obrazovanjem, ali je samo $10 \%$ njih uključeno u ovaj vid školovanja. Situacija sa srednjoškolskim obrazovanjem je još lošija, 514 osuđenika je bez srednje škole, a samo njih 15 pohađa srednju tehničku školu. Obrazovna struktura osuđenika gde je potpuno nepismenih $2,8 \%$, bez potpune osnovne škole $15,2 \%$, s osnovnom školom $26,5 \%$ i nedovršenom srednjom školom $6,6 \%$ ukazuje na potrebu za funkcionalnim osnovnim obrazovanjem odraslih i dokvalifikacijama i prekvalifikacijama. 
I ne samo obrazovna nego i starosna struktura osuđenika, gde je 68,5\% osuđenika starosti između 21 i 40 godina, upućuje na neophodnost takvih oblika obrazovanja.

$\mathrm{Na}$ osnovu podataka (UIZS) za 2011. godinu u srpskim zatvorima obrazovnim programima bilo je obuhvaćeno samo 316 osuđenika i 9 osuđenica što je oko $4 \%$ od ukupnog broja. Opismenjeno je 49 ili $0,7 \%$ lica; osnovnu školu završilo je 45 ili $0,6 \%$; tečajeve je pohađalo 167 ili oko $2 \%$ muškaraca i ni jedna žena; manje od 1\% (64) muškaraca je završilo treći stepen SSS i ponovo nijedna osuđenica. I tu, na sreću, nije kraj obrazovanju osuđenika kao organizovanom obliku tretmana. Krajem 2012. godine, u okviru projekta „Podrška stručnom obrazovanju i obuci u zatvorskim ustanovama Srbije,, počele su obuke u Požarevcu, Nišu i Sremskoj Mitrovici u kojima se sprovodi pilot VET obuke. Oko pet stotina osuđenika iz navedenih zatvora dobilo je priliku da odabere jedno od pet zanimanja: zavarivanje, štampanje sito štampom, obrada drveta i izrada pločastog nameštaja, izrada raznih vrsta pekarskih proizvoda i proizvodnja ranog voća i povrća u zaštićenom prostoru. Odabrana zanimanja su već dugo deficitarna na tržištu rada u Srbiji i obuka će se sprovoditi do septembra 2013. godine. Na osnovu prvih izveštaja broj osuđenih koji su zainteresovani za obuku se povećava i dobar primer je osuđenika iz KPZ Niš, koji je odbio da traži smanjenje kazne da bi završio obuku koju je započeo (www.vet-kpz.rs ).

Očekujemo da će pilot VET obuke prerasti u stalan proces i da će osuđenici koji nemaju nikakvo zanimanje dobiti mogućnosti obuke za konkretna zanimanja kao i za dokvalifikacije i prekvalifikacije. Na taj način bi se obrazovanjem i obukom osposobili, kvalifikovali, prekvalifikovali ili dokvalifikovali za neki posao i time osnažili za samostalan život. Poznato je da zatvor, bez smislenog i dobro organizovanog obrazovanja i obuke, često produbljuje uslove da osuđenici po izlasku na slobodu nastave sa onim zbog čega su i dospeli u zatvor. Po rečima mnogih osoba na izdržavanju zatvorske kazne zatvor predstavlja ,školu života, gde se stiču i usavršavaju mnogi „zanati,, i gde se „mentori,, nameću po jačini kriminalnog iskustva. Mnogima, u poslednjih dvadesetak godina, ništa drugo nije ni preostajalo nego da usavrše ono zbog čega su se i ,sklonili,, tu gde jesu.

Obrazovanje bi trebalo da se zasniva na objektivnim potrebama i mogućnostima osuđenih lica kako bi imalo efekta, jer prisilno obrazovanje, kao ni bilo koja druga prinuda ne može biti uspešno. Svaka vrsta obrazovanja, obuke i osposobljavanja za profesiju trebalo bi da počne od ispitivanja potreba i mogućnosti (finansijskih, organizacionih, kadrovskih) da se te potrebe 
zadovolje. Zbog čega onda ne pružiti priliku i osuđenicima da izraze svoje potrebe i interesovanja i saglase se sa tretmanom koji bi im, sigurni smo, na taj način efikasnije pomogao da promene neke svoje, bar radne, navike i stavove. Tretman bi trebalo bazirati na ispitanim potrebama, obrazovanju pre zatvora, psiho-fizičkim sposobnostima kao i na poznavanju potreba za zanimanjima u zatvoru i mogućnostima zaposlenja na slobodi. Zadatak organizovanja obrazovanja i obuke osuđenika nije nimalo jednostavan i nadamo se da će obuka savetnika iz Nacionalne službe za zapošljavanje koja je održana u martu 2013. u Kovačici olakšati posao motivisanja i aktiviranja osuđenika za stručno obrazovanje i obuku u zatvorskim ustanovama Srbije (www.vet-kpz.rs).

Prema podacima Helsinškog odbora za ljudska prava (2010) povratništvo u KPZ Sremska Mitrovica je oko 70\%. Veliki broj povratnika (među njima onih sa krivičnim delima nasilja i zloupotrebe droge) dovoljno govori o potrebi iznalaženja drugačijih, efikasnijih načina i oblika rada u zatvoru, ali i prihvata po izlasku iz penalnih ustanova. Iako se često recidivizam uzima kao indikator uspeha tretmana koji se primenjuje u toku izdržavanja zatvorske kazne, ostaje otvoreno pitanje koliko na tu veoma kompleksnu pojavu utiče: odmeravanje kazne, kategorizacija i klasifikacija u zatvoru (tretman koji se primenjuje, osoblje zatvora, neformalni sistem osuđenika koji se formira, kontakti sa spoljnim svetom) i postpenalni tretman, koji postoji samo na papiru.

Podaci o obrazovnoj strukturi osuđenika kojima raspolažemo dovoljno govore da se suočavamo sa problemima nepismenosti, elementarnim osnovnim obrazovanjem odraslih i visokim procentom nekvalifikovanih. Prema tome, obrazovanje u zatvorima bi trebalo usmeriti na elementarno opšte obrazovanje, sticanje osnovnih životnih veština i početnog stepena stručne osposobljenosti neophodne za uspešno uključivanje u rad. Taj nivo obrazovanja, tzv. funkcionalno osnovno obrazovanje odraslih, trebalo bi zaista prilagoditi odraslima umesto da se kao do sada obavlja po nastavnim planovima i programima redovne osnovne škole (razlika je bila samo u trajanju jer odrasli u toku jedne školske godine završavaju dva razreda). Novi oblici rada, metode i programi zahtevali bi nove udžbenike, andragoško-didaktički osposobljene nastavnike i instruktore (Knežić, Savić, 2012). 


\section{Istraživanje}

S obzirom na ulogu i značaj koju obrazovanje i edukativni programi u zatvoru mogu imati u procesu resocijalizacije, a na objektivno malo učešće osuđenika u postojećim obrazovnim aktivnostima u kazneno-popravnim ustanovama u Srbiji, krajem 2011. godine urađeno je istraživanje koje je imalo za cilj da ispita odnos osuđenika prema učestvovanju u obrazovanju u zatvoru.

Istraživanjem smo želeli da ispitamo da li kod osuđenika postoji motivacija za nastavak neke vrste obrazovanja i ukoliko postoji, koja vrsta obrazovnih sadržaja je u pitanju. Zanimalo nas je koji su razlozi zbog kojih osuđenici ne žele da učestvuju u edukativnim aktivnostima. Takođe nas je zanimalo mišljenje osuđenika o tome šta bi trebalo menjati u tretmanu, tj. koje aktivnosti bi trebalo uvesti.

Istraživanje je rađeno na uzorku od 260 osuđenika iz dve kaznenopopravne ustanove, Zabela (50 osuđenika) i Sremska Mitrovica (210 osuđenika). Uzorak je bio prigodan, tj. osuđenici su se dobrovoljno prijavili za učešće u istraživanju, a jedini uslov bio je da su pismeni.

Osuđenici su popunjavali kratak upitnik sa zatvorenim i poluotvorenim pitanjima. Jedan deo upitnika odnosio se na: starost osuđenika, obrazovanje, broj ranijih osuda. Pitanja u drugom delu upitnika odnosila su se na to da li bi osuđenik želeo da nastavi školovanje dok je na izdržavanju kazne, koju vrstu sadržaja bi voleo da uči, njegovo mišljenje da li obrazovanje utiče na promenu ponašanja i mišljenja, da li je osuđenik uposlen u KPZ-u i šta bi po njegovom mišljenju trebalo menjati u tretmanu osuđenika.

Uzorak je obuhvatio osuđenike starosti između 22 i 73 godine. Najviše osuđenika ima u kategoriji mlađeg srednjeg doba, između 25 i 40 godina $66 \%$, dok ih je najmanje u kategoriji preko 55 godina - 9\% (Tabela 1).

\section{Tabela 1.}

\begin{tabular}{|c|c|c|}
\hline Starost osuđenika & $\mathbf{N}$ & $\%$ \\
\hline do 25 & 26 & 10 \\
\hline 25 do 40 & 172 & 66 \\
\hline 40 do 55 & 39 & 15 \\
\hline preko 55 & 23 & 9 \\
\hline$\Sigma$ & 260 & 100 \\
\hline
\end{tabular}


U svođenju negativnih efekata učenja, koje se odvija između osuđenika, na najmanju moguću meru $76,2 \%$ osuđenika iz našeg uzorka starosti do 40 godina predstavlja značajnu ciljnu grupu za organizovanje najraznovrsnijih oblika obrazovanja.

S obzirom na nivo obrazovanja, u uzorku dominira kategorija osuđenika koja ima završenu srednju školu (treći ili četvrti stepen) - 40\%. Nepotpunu srednju školu ili samo osnovnu ukupno ima 46\% ispitanika, a nepotpunu osnovnu školu 10\% ispitanika. Procentualno najmanje zastupljena kategorija osuđenika je, kao i u opštoj populaciji, sa završenom višom školom ili fakultetom $-4 \%$.

U našem uzorku je oko $80 \%$ osuđenika bar jednom ranije bilo osuđivano, a čak 47\% više puta (između 2 i 13 puta).

$\mathrm{Na}$ pitanje da li bi želeli da nastave školovanje dok su u zatvoru, 55\% ispitanih osuđenika odgovara da bi želelo, dok 43\% ne želi.

Kada se ukrste podaci o želji za nastavkom školovanja i starost osuđenika (Tabela 2), dobija se značajna razlika $\left(\chi^{2}(3)=11,88, p<0.01\right)$, koja potiče od toga što među ispitanicima ispod 40 godina ima više onih koji bi želeli da nastave školovanje, dok među onima preko 40 godina ima manje takvih.

\section{Tabela 2.}

\begin{tabular}{|c|c|c|c|}
\hline \multirow{2}{*}{ do $\mathbf{2 5 g}$} & \multicolumn{3}{|c|}{ Da li žele nastavak školovanja } \\
\cline { 2 - 4 } & $\mathbf{d a}$ & ne & $\Sigma$ \\
\hline \multirow{2}{*}{$\mathbf{2 5}$ do 40g } & 17 & 8 & 25 \\
\hline \multirow{2}{*}{$\mathbf{4 0}$ do 55g } & $68 \%$ & $32 \%$ & $100 \%$ \\
\hline \multirow{2}{*}{ preko 55g } & 104 & 65 & 169 \\
\hline \multirow{2}{*}{$\Sigma$} & $61,5 \%$ & $38,5 \%$ & $100 \%$ \\
\hline & 15 & 24 & 39 \\
\hline & $38,5 \%$ & $61,5 \%$ & $100 \%$ \\
\cline { 2 - 4 } & 8 & 14 & 22 \\
\hline
\end{tabular}


Ovaj nalaz je i očekivan s obzirom na to da se u našem društvu, a u zatvorskoj sredini je to još izraženije, na obrazovanje još uvek gleda kao na obavezu dece i mladih, a ne na celoživotni proces učenja i razvoja. Ono što može da demotiviše osuđenike za učešće u obrazovanju jeste i to što pojedinci ne vide svrhu i korist od obrazovanja. Zbog toga je uloga zatvorskog osoblja od velikog značaja naročito za motivisanje starijih osuđenika za obrazovanje, pohađanje raznovrsnih tečajeva i predavanja na različite, za njih zanimljive i relevantne teme (npr. zdravlje, ishrana, istorija, religija).

U Tabeli 3. ukršteni su podaci o dužini kazne osuđenika i želji da nastave školovanje. Pokazalo se da među osuđenicima sa dužim zatvorskim kaznama, preko 5 i 10 godina, postoji znatno više onih koji žele da nastave školovanje $\left(\chi^{2}(3)=20,539, \mathrm{p}<0.01\right)$.

\section{Tabela 3.}

\begin{tabular}{|c|c|c|c|}
\hline \multirow{2}{*}{ Dužina kazne } & \multicolumn{3}{|c|}{ Da li žele nastavak školovanja } \\
\cline { 2 - 4 } & $\mathbf{d a}$ & ne & $\Sigma$ \\
\hline \multirow{2}{*}{ do 2 god } & 19 & 29 & 48 \\
\hline \multirow{2}{*}{$2-5$ god } & $39,6 \%$ & $60,4 \%$ & $100 \%$ \\
\hline \multirow{2}{*}{$\mathbf{5}-\mathbf{1 0}$ god } & 48 & 54 & 102 \\
\hline \multirow{2}{*}{ preko 10 god } & $47,1 \%$ & $52,9 \%$ & $100 \%$ \\
\cline { 2 - 4 } & 42 & 17 & 59 \\
\hline \multirow{2}{*}{$\boldsymbol{\Sigma}$} & $71,2 \%$ & $28,8 \%$ & $100 \%$ \\
\hline & 33 & 11 & 44 \\
\hline & $75 \%$ & $25 \%$ & $100 \%$ \\
\hline
\end{tabular}

Većina osuđenika koji su na odsluženju kazne koja traje preko pet godina učestvovanje u obrazovanju vide kao način da daju smisao ,pauziranju” od svakodnevnog života, a takođe i način da ispune dugo i sumorno zatvorsko vreme. Pa ako je i to razlog uključivanja u obrazovanje trebalo bi ga osmisliti i oživotvoriti kako zatvor ne bi postao ,skup način da se loši ljudi učine još gorim” (Home Office, 1988, prema Wilson, Reuss, 2000). 
Odgovore svih osuđenika na pitanje zašto žele da nastave obrazovanje razvrstali smo u pet kategorija koje su navedene prema redosledu zastupljenosti:

- doživotno obrazovanje, rad na sebi, želja za obrazovanjem, usavršavanje, želja za novim znanjem;

- mogućnost zaposlenja po isteku kazne;

- kvalitetno korišćenje slobodnog vremena;

- završetak započetog školovanja i

- želja za promenom posla.

Zanimljivo je da je motiv za obrazovanjem koji je najzastupljeniji - rad na sebi ili neka vrsta želje za usavršavanjem, a da su tek posle njega zastupljeni konkretniji, praktičniji motivi kao što je pronalaženje posla, promena posla ili završetak započetog školovanja.

Najčešći razlog osuđenika koji ne žele dalje da se obrazuju jeste zadovoljstvo postignutim nivoom obrazovanja i znanjima koja već poseduju (33\% odgovora). Jedan deo osuđenika navodi da nema motiva za dalje školovanje, da ne žele i ne treba im dalje obrazovanje (24\% odgovora). Grupa osuđenika kao razlog navodi to što su već stari da se dalje školuju, iako je većina njih u tridesetim i četrdesetim godinama $\mathrm{i}$ ima još dobar deo radnog veka pred sobom (18\% odgovora). Preostali motivi koje navode mogli bi se svrstati u objektivne ( $25 \%$ odgovora) - nepostojanje uslova u zatvoru, dužina preostale kazne i bolest ili invaliditet.

Većina ispitanih osuđenika - 75\%, smatra da obrazovanje utiče na promenu ponašanja i mišljenja, spram 13\% koji ne misle tako. Moglo bi se reći da većina ispitanih osuđenika vidi obrazovanje kao mogući faktor promene u životu, ali da je veoma mali broj njih spreman da iskoristi tu mogućnost za promenu. Kao što smo ranije pomenuli, preko $50 \%$ ispitanih osuđenika bi želelo da se uključi u neki vid edukacije, što je broj koji mnogostruko premašuje realan broj osuđenika uključenih u edukaciju u zavodima. Ako kao jedan od razloga izuzmemo davanje socijalno poželjnih odgovora, ostaje mogućnost da osuđenici ne vide ponuđene edukativne programe kao odgovarajuće njihovom potrebama, odnosno ne vide direktnu vezu tako koncipiranog obrazovanja sa životom na slobodi i mogućnošću zapošljavanja ili unapređivanja sebe i svojih sposobnosti i znanja.

$\mathrm{Na}$ pitanje sa ponuđenim odgovorima šta bi menjali u tretmanu osuđenici su se najviše opredeljivali za odgovor - uposliti sve (33\% odgovora), zatim za odgovor - organizovati obrazovanje i osposobljavanje za zanimanje ( $12 \%$ odgovora), pa organizovati kulturne, sportske, zabavne aktivnosti (11\% odgovora) i na kraju organizovati predavanja na neke teme ( $9 \%$ odgovora). 
Osuđenici koji smatraju da bi trebalo organizovati kulturne, sportske, zabavne aktivnosti navode: sportska takmičenja, turnira, pozorišnih predstava, bioskopa, koncerata, sekcija (šahovska, dramska, muzička). Neke od ovih aktivnosti već i postoje u zavodima, pri čemu za sportske postoji i najveće interesovanje i najveća uključenost osuđenika. Najveći broj ispitanika se opredeljuje za više odgovora (35\%).

Iz navedenih rezultata istraživanja vidljivo je da postoje pozitivni pokretači na obrazovanje i u zatvoru koji mogu podstaći osuđenike da uče s namerom da na neki način nadoknade propušteno u svom dotadašnjem obrazovanju i da bar izvuku neku korist od neslobode. Motivacija i raznolikost mogućnosti obrazovanja, više nego na drugim mestima i u drugim okolnostima, značajan su preduslov za uspešno obrazovanje u zatvoru. Uloga osoblja u zatvoru, pogotovo službi za tretman i obuku, od velike je važnosti kada je u pitanju informisanost osuđenika o pravima i mogućnostima obrazovanja i obuke. Poznato je da obrazovna motivacija zavisi od socio-demografskih karakteristika i da se njihovim promenama u različitim periodima životnog ciklusa menjaju i interesovanja i motivi za obrazovanjem. Programski sadržaji bi trebalo da prate te promene, potrebe i interesovanja pojedinaca. Jedino u takvim okolnostima čovek može i kada je u zatvoru, imati motivaciju i interesovanje za sticanje znanja i kvalifikacija, što mu po izlasku iz zatvora može pomoći prilikom zaposlenja. Osećanja poniženja, sumnja u vlastite sposobnosti, nedostatak motivacije, bezvoljnost, umor, ograničenost na osoblje zatvora, mogu doprineti neuključivanju u proces obrazovanja i osposobljavanja.

\section{Zaključna razmatranja}

Prednosti programa obrazovanja u zatvorima čine se nesporne imajući u vidu dobrobit svakog od pojedinaca uključenog u njega kao i dugoročnu korist za celo društvo koje će imati produktivnog člana zajednice. Zakonom (ZIKS) je prilično dobro određena uloga i značaj obrazovanja, obuke i osposobljavanja, ali nažalost, tih oblika aktivnosti je veoma malo u penalnim ustanovama. Zakonsko pravo na obrazovanje trebalo bi pretočiti u smisleno obrazovanje uporedivo sa onim van zatvora, koje će zadovoljiti potrebe osuđenika u zatvoru i nakon izlaska iz njega.

Obrazovno i svrsishodno radno angažovanje osuđenika načini su ispunjavanja svrhe zatvorske kazne, a ti oblici tretmana su u praksi nesrazmerni sa ulogom koju imaju, potrebama društva i pojedinca u ostvarivanju cilja kažnjavanja, koji se ne zasniva samo na represiji i očuvanju reda i kontrole. 
Stoga bi trebalo:

- uspostaviti bolju saradnju između pojedinih ministarstava (finansija, pravosuđa, prosvete, kulture, rada i socijalne zaštite) kao i zatvora i lokalne zajednice;

- utvrditi obrazovni nivo i ispitati obrazovne potrebe osuđenika kao i potrebe za određenim zanimanjima u zatvoru i na tržištu rada, pa u zavisnosti od sposobnosti i interesovanja osuđenika i trajanja njihove kazne odrediti vrstu osposobljavanja;

- stručno planirati obrazovne aktivnosti osuđenika. Planove i programe osposobljavanja treba osavremeniti i prilagoditi promenama kako bi bili u skladu s aktuelnim stanjem u praksi;

- motivisati osuđenike za uključivanje u obrazovanje i stručno osposobljavanje organizovanjem različitih kampanja, jer je poznato da su osuđenici veoma heterogena grupa, različitog socijalnog porekla, nivoa obrazovanja, porodičnog statusa, vrste krivičnog dela zbog kojeg su u zatvoru;

- poboljšati kadrovsku strukturu, obučiti i osposobiti osoblje za rad u specifičnoj sredini kao što je zatvor i sa još specifičnijom populacijom kao što su osuđenici. Vaspitačima treba vratiti ugled koje to ime zaslužuje, a ne da se njihov rad svodi na povremene kratke razgovore, čitanje i cenzuru pisama ili, kako misle osuđenici, na cinkarenje.

Podaci istraživanja ukazuju da postoje osuđenici koji žele da učenjem novih sadržaja ispune slobodno vreme. Od osoblja i osuđenika se saznaje da su sportsko-rekreativne i kulturno-zabavne aktivnosti zapostavljene, a u njima bi većina osuđenih učestvovala. Kod nas su razmišljanja o obrazovanju u zatvoru još uvek rigidna jer ga jedni poistovećuju sa učenjem pisanja i čitanja, prisećajući se analfabetskih tečajeva, a drugi nipodaštavaju njegov značaj kada su u pitanju oni koji su se „ogrešili,, o zakone. Iluzorno je očekivati rezultate, ako država ne vidi u obrazovanju mehanizam promene i sredstvo kojim će pomoći reintegraciju osuđenika u društvo. 


\title{
PRISON EDUCATION: FROM THE RIGHT TO REALISATION ${ }^{6}$
}

\begin{abstract}
- Abstract -
Increasing number of returnees, congestion of prisons and bad conditions in prisons do not indicate that the society is coping with delinquency in best possible way. Since 1980s in most western countries and in our country also the concept of social rehabilitation is being criticised for not bringing a drop in the crime rate or recidivism. Problem which societies are facing is how to prepare prisoners, while they still serve a sentence, for integration into society once they have left prison. To achieve this goal education can play a very important role. In this article we will treat different aspects of prison education: how it is regulated by the state and what is its purpose, what is the current situation in our and other countries for prisoners to embrace their right to education, what are the obstacles for education in prisons. One of the main preconditions for implementation and success of education programmes in prisons is the motivation of inmates to participate. We will show one part of the study conducted in two correctional facilities (Požarevac and Sremska Mitrovica) on motivation of prisoners for education and their educational needs.
\end{abstract}

Keywords: education, prisoners, recidivism, rehabilitation, prison environment.

6 Article presents the results of the project „Crime in Serbia: phenomenology, risks and possibilities of social intervention" (Number 47011) financed by Ministry of education, science and technological development of Republic Serbia (2011-2014). 


\section{Literatura}

- Boshier, R. (1985). Adult Education: Motivation of Participants, Oxford: L.E.E Pergamon Press.

- Bozos, A. \& Hausman, J. (2004). Correctional Education as a Crime Control Program. UCLA School of Public Policy and Social Research, Department of Policy Studies.

- Cecil, D., Drapkin, D. A., MacKenzie, D. L., \& Hickman, L. J. (2000). The Effectiveness of Adult Basic Education and Life-Skills Programs in Reducing Recidivism: A Review and Assessment of the Research. Journal of Correctional Education, 51(2), p. 207-226.

- European Conference on Prison Education, „Pathways to inclusion - Strengthening European Cooperation in Prison Education and Training”, Budapest, 22-24 February 2010. http://ec.europa.eu/ education/grundtvig/doc/conf11/a7report.pdf.

- Francis, N.T. (2010). The Effect of Education Programs on Prisoner Recidivism in Michigan.Northern Michigan University.

http://www.nmu.edu/sites/DrupalEducation/files/UserFiles/Files/PreDrupal/SiteSections/Students/GradPapers/Projects/Nelson_Taryn_ MP.pdf.

- Gaes, G. (2008). The Impact of Prison Education Programs on PostRelease Outcomes. Paper presented at the Reentry Roundtable on Education, John Jay College of Criminal Justice, New York.

- Gehring, T. (2000). Recidivism as a measure of correctional education program success. Journal of Correctional Education, 51, p. 197-205.

- GHK (2011). Prison education and training in Europe - a review and commentary of existing literature, analysis and evaluation. Directorate General for Education and Culture, European Commission.

- Harer, M.D. (1994). Recidivism among federal prison releasees in 1987: A preliminary report. Washington DC: Federal Bureau of Prisons.

- Harer, M.D. (1995). Prison Education Program Participation and Recidivism: A Test of the Normalization Hypothesis. Washington, DC: Federal Bureau of Prisons, Office of Research and Evaluation.

- Home Office (1988). Punishment, Custody and the Community. London: HMSO.

- Hull, K., Forrester, S., Brown, J., Jobe, D., McCullen, C. (2000). Analysis of Recidivism Rates for Participants of the Academic/ 
Vocational/Transition Programs Offered by the Virginia Department of Correctional Education. Journal of Correctional Education, 51(2), p. 256-261.

- Izveštaj o radu Uprave za izvršenje krivičnih sankcija za 2011. http://www.uiks.mpravde.gov.rs/cr/articles/izvestaji-i-statistika/.

- Izveštaj o radu Uprave za izvršenje krivičnih sankcija za 2010. http://www.uiks.mpravde.gov.rs/cr/articles/izvestaji-i-statistika/.

- Kling J.R.(2006). Incarceration, Length, Employment, and Earnings. The Brookings Institution and National Bureau of Economic Research. http://www.nber.org/ kling/494.pdf.

- Knežić, B. (2001). Obrazovanje i resocijalizacija - metode merenja, Beograd, Zavod za udžbenike i nastavna sredstva.

- Knežić, B., Savić, M. (2012). Obrazovanje iza rešetaka. U Kron, L. (ur.) Delikt, kazna i mogućnosti socijalne profilakse. Institut za kriminološka i sociološka istraživanja, Beograd, str. 179-193.

- Kosmidou, A. (2011). Education behind Bars: The Case of Sweden. Andragoške studije, br. 1, str. 119-133.

- Lewis, J. (2006). Correctional education: Why it is only promising, Journal of Correctional Education, 57(4), p. 286-296.

- MacKenzie, D.L. (2006). What Works in Corrections: Reducing the Criminal Activities of Offenders and Delinquents. Cambridge University Press.

- Ripley, P. (1993). Prison Education Role in Challenging Offending Behaviour. Mendip Papers MP 047.

- Soferr, S. (2006). Prison Education: Is It Worth It? Corrections Today, Vol. 68, Issue 6.

- Steurer, S.J.\& Smith,L.G.(2003). Education Reduces Crime: ThreeState Recidivism Study Executive Summary, Correctional Education Association. www.ceanational.org/PDFs/EdReducesCrime.pdf.

- Stevanović, Z. (2012). Zatvorski sistem u svetu. Institut za kriminološka i sociološka istraživanja Beograd.

- Vacca, J.M. (2004). Educated Prisonersa Are Less Likely To Return to Prison, The Journal Of Correctional Education, 55(4), p. 297-305.

- Wade, B. (2007). Studies of correctional education programs. Adult basic Education and Literacy Journal, 1(1), p. 27-31.

- Walmsley, R. (2012). World Prison Population List ( $9^{\text {th }}$ edition).

- Wilson, D., Reuss, A. (2000). Prison(er) Education. Waterside Press.

- Zakon o izvršenju krivičnih sankcija i Izmene zakona o izvršenju 
krivičnih sankcija, Službeni glasnik RS, br. 85/2005 i br. 72/2009.

- Zatvori u Srbiji. Praćenje reforme zatvorskog sistema u Srbiji (2010). Helsinški odbor za ljudska prava u Srbiji.

- UN Human Rights Council (2009). The right to education of persons in detention: report of the Special Rapporteur on the Right to Education, Vernor Muñoz, available at: http://www.refworld.org/ docid/4a00419d2.html [accessed May 2013].Zarfa Hrnjić Kuduzovic ${ }^{7}$

7 Doc. dr. Zarfa Hrnjić Kuduzović, Fakultet političkih nauka, Univerzitet u Sarajevu 
Mustafa Šuvalija ${ }^{1}$

UDK: $615.851: 37.014$

\section{OSPOSOBLJAVANJE UNIVERZITETSKIH NASTAVNIKA ZA EFIKASNIJI ODGOJNO-OBRAZOVNI RAD KROZ UPOTREBU KOGNITIVNO-BIHEVIORALNIH PRINCIPA TERAPIJSKOG RADA}

\section{- Sažetak -}

Stavovi studenata prema obrazovanju predstavljaju jednu od važnih determinanti njihove motivacije za učenje i akademskog uspjeha. Posjedovanje efikasnih alata za modificiranje tih stavova onda kada njihov sadržaj ne pogoduje akademskoj uključenosti i uspjehu olakšalo bi nastavnicima vršenje njihove odgajateljske i nastavničke uloge. S obzirom da kognitivna terapija predstavlja visoko efikasan terapijski pristup koji zagovara promjenu ponašanja kroz mijenjanje uvjerenja (uključujući i stavove), prilagodba njenih osnovnih principa i tehnika obrazovnom kontekstu za svrhe modificiranja obrazovno relevantnih stavova te podučavanje nastavnika kognitivno zasnovanim odgojnim tehnikama moglo bi zadovoljiti potrebu za jednim takvim alatom. U radu je predstavljena teoretska razrada mogućnosti integracije principa i tehnika kognitivne terapije u nastavni proces u svrhu facilitiranja promjene stavova koji mogu nepovoljno djelovati na akademsku uključenost i uspjeh studenata.

Ključne riječi: stavovi prema obrazovanju, akademski uspjeh, kognitivni model, sokratovski metod.

1 Mustafa Šuvalija, diplomirani psiholog, student postdiplomskog studija na Odsjeku za psihologiju Filozofskog fakulteta Univerziteta u Sarajevu. Asistent na predmetu Psihologija na Fakultetu za kriminalistiku, kriminologiju i sigurnosne studije Univerziteta u Sarajevu. E-mail: msuvalija@fkn. unsa.ba. 


\section{Uvod}

Kognitivna terapija predstavlja jedan od najkorištenijih oblika psihoterapije u svijetu. Tu popularnost, čini se, najviše objašnjavaju njena efikasnost u rješavanju problema zbog kojih klijenti traže pomoć te jasnoća, razumljivost i racionalnost teorijskog modela ponašanja na kojem je zasnovana, poznatog pod imenom kognitivni model. Zanimljivo je primijetiti da svi oblici psihoterapije, uključujući i kognitivnu, imaju slične ciljeve onima koje ima obrazovanje, kao i to da te ciljeve postižu na sličan način na koji to radi obrazovanje. I psihoterapija i obrazovanje, između ostalog, imaju za cilj pomoći pojedincu da postigne vlastito blagostanje i osposobiti ga da se nosi sa određenim problemima sa kojima se susreće ili će se susretati; i psihoterapija i obrazovanje taj cilj postižu djelovanjem na pojedinca na, prije svega, mentalnoj ravni, povećavajući njegovo znanje i razumijevanje određenih problema i pojava. Zbog ovih sličnosti, čini se korisnim ispitivati teme koje su smještene na presjeku psihoterapije, s jedne, te pedagogije / andragogije i edukacijske psihologije s druge strane. Obrazovanje, u smislu obrazovnog sistema i procesa obrazovanja, već pomaže i omogućava psihoterapiji da realizira svoju misiju; primjenjivati psihoterapiju može samo neko ko je educiran da to radi, a gradivo vezano za različite vrste psihoterapije se, u različitoj mjeri i sa različitim ciljevima, predaje na velikom broju obrazovnih institucija širom svijeta. Postavlja se pitanje: da li psihoterapija može „uzvratiti uslugu,, i dati doprinos obrazovanju, učiniti proces obrazovanja efikasnijim a različite sisteme obrazovanja kvalitetnijim, i tako pomoći u postizanju ciljeva obrazovanja? Zbog ranije spomenutih karakteristika, bilo bi dobro ispitati tu mogućnost upravo kada je u pitanju kognitivna terapija, a posebno bi bilo zanimljivo takvo istraživanje provesti u odnosu na promjenu nepoželjnih stavova prema obrazovanju, s obzirom da su stavovi jedan od aspekata psihičkog života kojim se kognitivna terapija eksplicitno bavi, a stavovi prema različitim elementima obrazovanja i obrazovnog procesa nešto što, prema rezultatima različitih istraživanja, može imati uticaj na uspjeh obrazovnog procesa. U nastavku će biti detaljnije razmotreni razlozi zbog kojih bi primjena principa i tehnika kognitivne terapije u ovu svrhu bila dobra ideja te predstavljen prijedlog jednog načina na koji to može biti učinjeno.

\section{Stavovi i njihove komponente}

Stavovi predstavljaju jedan od središnjih pojmova u socijalnoj psihologiji i njihovo izučavanje ima dugu historiju. Međutim, kao što je slučaj i sa velikim 
brojem drugih pojava koje su predmet zanimanja psihologije, ne postoji jedna, opšteprihvaćena definicija stava. Tako, naprimjer, Gordon Allport (Allport, 1935, prema Šiber, 1998, str. 75), u jednoj od najranijih i najsveobuhvatnijih definicija stavova, stavove definira kao „mentalno i neuralno stanje spremnosti organizirano kroz iskustvo, koje neposredno ili dinamično utiče na odgovore pojedinca na sve objekte i situacije sa kojima je povezan,,. Newcomb (Newcomb, 1950, prema Pennington, 2004, str. 85) smatra da je stav „naučena sklonost reagiranju na dosljedno povoljan ili nepovoljan način s obzirom na dati objekt,.. Također, vrijedi spomenuti definiciju koju su dali Krech, Crutchfield i Ballachoy (Krech, Crutchfield i Ballachoy, 1962, prema Šiber, 1998, str. 75) po kojima je stav „trajna organizacija pozitivnog ili negativnog vrednovanja, emocionalnih osjećaja i tendencija da se reagira pozitivno ili negativno u vezi svoje okoline,., Važna zajednička karakteristika ove tri definicije jeste isticanje važnosti i uticaja stava na način na koji se odnosimo (reagujemo) prema onom dijelu stvarnosti koji predstavlja objekat stava.

Prema Šiberu (1998), to da su stavovi povezani sa ponašanjem je samo jedna od karakteristika koje su zajedničke za različite pristupe izučavanju stavova; to su još i:

- isticanje da su stavovi usmjereni na nešto, tj. da imaju svoj objekt,

- da imaju vrijednosnu dimenziju koja se izražava afektivnim odnosom sviđanja ili nesviđanja,

- da su naučeni, te

- da su relativno trajni jer usmjeravaju pojedinca kroz duže razdoblje.

Stavovi imaju tri komponente: kognitivnu, koja podrazumijeva uvjerenja i atribute koji se vezuju za objekt stava, afektivnu, koja podrazumijeva emocije vezane za objekt stava i bihevioralnu, odnosno ponašajnu, koja se, prema jednom viđenju, tiče načina na koji se u prošlosti ponašalo prema objektu stava (Hewstone, Stroebe i Jonas, 2012). Za ponašajnu komponentu, koja se još naziva i konativnom (akcionom), može se reći da ima veze sa ponašajnim tendencijama osobe u pogledu objekta stava. Treba napomenuti da su prema Fishbeinovoj teoriji ove ponašajne tendencije ustvari ponašajne namjere, koje kao takve nisu dio, već posljedica stava (koji u tom slučaju ima samo kognitivnu i emocionalnu komponentu), te su samo jednim dijelom determinirane stavom osobe prema datom ponašanju (Jaspars, 1978), što je vjerovatno bolji i precizniji način razumijevanja komponenti stava.

Razumijevanje stava kroz prizmu njegovih komponenti poznato je kao strukturalni pristup, a korisno je upravo zato jer nam, između ostalog, 
pomaže razumjeti kako stavove i sa njima povezane koncepte možemo koristiti za predviđanje ponašanja (Pennington, 2004). Veza između stavova i ponašanja, odnosno tzv. prediktivna vrijednost stavova, važna je u kontekstu relevantnosti istraživanja stavova prema obrazovanju i svim konceptima koji su povezani sa uspjehom u obrazovanju, a koji mogu biti objekt stava; ukoliko stavovi zaista jesu povezani sa ponašanjem prema objektima tih stavova, onda stavove u ovom kontekstu ima smisla istraživati, a njihovo mijenjanje u pravcu povoljnije procjene tih objekata može omogućiti bolji, produktivniji odnos prema obrazovanju. Iako se možda čini zdravorazumski pretpostaviti da veza između stavova i ponašanja nesumnjivo postoji, odnosno da stavovi utiču na ponašanje, istraživanja u socijalnoj psihologiji nisu uvijek davala jednoznačne rezultate u tom pogledu. Konkretno, istraživanja koja su se počela pojavljivati pred kraj 1960-ih, kao što je ono koje je proveo Wicker 1969. godine, nisu pokazivala visoku korelaciju između stavova i ponašanja; Wicker je čak ustvrdio kako je vjerovatnije da između stavova i ponašanja ne postoji nikakava veza, ili da je ona veoma slaba, nego da između njih postoji bliska veza (Smith i Swinyard, 1983). Ne želeći ulaziti detaljnije u historiju rasprava o vezi stavovi - ponašanje, treba reći da su kasnija istraživanja, ,isprovocirana,, dobrim dijelom Wickerovim nalazom, pokazala da stavovi ipak utiču na ponašanje (Myers, 2012). Međutim, da bi se to desilo moraju biti ispunjeni određeni uslovi. Metaanaliza 88 studija koju je sproveo Kraus (Kraus, 1995, prema Baumeister i Bushman, 2008) pokazala je da su stavovi koji su posebno dobri za predviđanje ponašanja zasnovani na direktnom iskustvu, dosljedni, stabilni, dostupni (što znači da postoji jaka veza između objekta stava i evaluativne reakcije na taj objekt), te da je ubijeđenost, odnosno sigurnost u ispravnost tog stava velika. Myers (2012) navodi da je uticaj stavova na ponašanje značajan ako su ispunjena tri uslova: da su stavovi specifični za to ponašanje ( $\mathrm{tj}$. da nisu previše generalizirani), da smo ih svjesni i da su vanjski uticaji na naše ponašanje minimalni (tj. da svoje ponašanje ne moramo prilagođavati nekome ili nečemu drugom). Istraživanja vezana za važnost stavova u obrazovnom procesu, neka od kojih će biti razmotrena u nastavku, potvrđuju postojanje značajne veze između stavova i ponašanja.

\section{Obrazovno specifični stavovi kao determinanta obrazovnog uspjeha}

Prema McCoachu i Siegleu (2003a), stavovi prema školi, nastavnicima i predmetima predstavljaju karakteristike koje su u različitim istraživanjima dovedene u vezu sa akademskim uspjehom, zajedno sa akademskim 
samopoimanjem, vrednovanjem ciljeva, te motivacijom i samoregulacijom. Pri tome treba imati na umu da su i vrednovanje ciljeva i akademsko samopoimanje također povezani sa stavovima, koji se odnose na obrazovanje. Naprimjer, istraživanje koje je proveo Haslett (1976) pokazalo je da je akademsko samopoimanje studenata, koje se prema McCoachu i Siegleu (2003a) odnosi na vjerovanja o vlastitoj vrijednosti u smislu akademske kompetentnosti, u značajnoj korelaciji sa načinom na koji se ocjenjuju nastavnici i njihova efikasnost, što, prema mišljenju B. J. Haslett, znači da akademsko samopoimanje studenata ima uticaj na način na koji studenti procjenjuju i reaguju na svoje obrazovno iskustvo. S druge strane, vrednovanje ciljeva kao determinanta obrazovnog uspjeha zasnovano je na primjeni postavke teorije vrijednosti očekivanog (eng. expectancy-value theory) na motivaciju, prema kojoj motivacija i samoregulacija vezani za učenje ovise u značajnoj mjeri od vrijednosti vezanih za postignuće; ove vrijednosti obuhvataju uvjerenja vezana za zanimljivost i važnost zadataka kao i percepciju njihove korisnosti (Pintrich i DeGroot, 1990, Wigfield i Karpathian, 1991, prema McCoach i Siegle, 2003a). Vrednovanje ciljeva neke aktivnosti može biti objašnjeno u terminima stavova, pri čemu je stav prema samoj aktivnosti funkcija stava o vrijednosti očekivanog (eng. expectancy-value attitude), odnosno stava, koji se odnosi na različite posljedice te aktivnosti (Yi, 1989). Iz ovog slijedi da je za mijenjanje određenih stavova relevantnih za akademsko postignuće neophodno znati nešto i o samopoimanju i o vrijednostima studenta vezanim za aktivnosti u obrazovnom procesu.

Kada su u pitanju stavovi prema školi, u najkraćem, učenici koji postižu slabije rezultate ispoljavaju negativne stavove prema školi (Mandel i Marcus, 1988, prema McCoach i Siegel, 2003b). Slične rezultate daju i istraživanja o vezi između stavova prema pojedinim predmetima i uspjeha na tim predmetima. Naprimjer, Wilson (1983, prema Curtis, 2006) je utvrdio da pozitivni stavovi učenika prema prirodnim naukama visoko koreliraju sa njihovim uspjehom u toj oblasti. Schunk (Schunk, 1989, prema Ajayi, Lawani i Salomi, 2012) tvrdi da je od svih varijabli koje su važne za uspjeh u matematici, stav prema matematici najvažniji. Do sličnog zaključka došao je i Schreiber (Schreiber, 2002, u Manoah, Indoshi i Othuon, 2011), tvrdeći da oni koji imaju pozitivan stav prema matematici postižu i veći uspjeh u ovom predmetu. Osim samih predmeta, važni su i stavovi prema nastavnicima; naprimjer, Peters, Grager-Loidl i Supplee (Peters, Grager-Loidl i Supplee, 2000, u McCoach i Siegle, 2003a) tvrde da ličnost nastavnika može uticati na uspjeh učenika u nastavi. Ispitivanja McCoacha i Sieglea nisu bila usmjerena 
na studente na fakultetskom nivou obrazovanja, ali istraživanja koja jesu dala su rezultate slične onima o kojima su oni izvijestili. Naprimjer, prema House (House, 1995, prema Benford i Gess-Newsome, 2006) stavovi prema hemiji predstavljaju jedan od boljih prediktora uspjeha na tom predmetu na fakultetskom nivou. U istom radu, Benford i Gess-Newsome citiraju i veći broj istraživanja (Weinburgh 2000, Weinburgh 1994, Oliver i Simpson 1988, Kaballa i Crowley 1986, Willson 1983, Gardner 1975, Ormerod i Duckworth 1975) koja ukazuju da su pozitivni stavovi prema prirodnim naukama povezani sa boljim uspjehom u predmetima iz te oblasti. Tett (1999) je, ispitujući prepreke pristupu i održivom učešću u visokoškolskom obrazovanju osoba crne boje kože sa invaliditetom, utvrdio da je njihovo zadržavanje u sistemu visokoškolskog obrazovanja potpomognuto sa tri faktora: zanimljivost i ohrabrujući pristup osoblja, kvalitet odnosa sa drugim studentima, adekvatnost sadržaja pohađanog smjera te posvećenost studenta smjeru i instituciji. Ovi faktori se u određenoj mjeri preklapaju sa determinantama za koje McCoach i Siegle smatraju da utiču na uspjeh u školi (stav prema nastavnicima, prema njihovim časovima i stav prema školi odnosno učenju).

Ispitivanja stavova studenata i učenika često imaju za cilj dobijanje uvida o tome u kom pravcu treba prilagođavati i poboljšavati nastavni proces da bi se na taj način stavovi studenata i učenika prema nastavi promijenili nabolje. Naprimjer, Weidmann i Humphrey (Weidmann i Humphrey, 2002, prema Manoah, Inoshi i Othuon, 2011), smatraju da se uvidom u stavove o matematici dobijaju kako informacije o potrebama studenata tako i informacije koje mogu biti katalizator promjene u nastavi matematike. Ovaj pristup je svakako legitiman, međutim čini se da on ne uzima u obzir mogućnost promjene stavova studenata i učenika na način, koji ne podrazumijeva promjene u samom objektu stava (školsko okruženje, ponašanje i način predavanja nastavnika i sl.), već u percepciji tog objekta i, još važnije, njegovoj ocjeni, odnosno u kognitivnoj i afektivnoj komponenti stava. Više se važnosti daje mijenjanju objektivne stvarnosti nego mijenjaju subjektivnog doživljaja te stvarnosti. Ako uzrok nepoželjnog odnosa prema školi zaista proizlazi iz neadekvatnosti onoga što je vanjsko (npr. grešaka koje profesor pravi u odnosu prema studentima), onda mijenjanje „,vanjskog, jeste put kojim treba ići; međutim, pogrešno bi bilo pretpostavljati da uzrok problema može ležati samo ili čak primarno u vanjskim faktorima. Također, čini se još više pogrešnim prepoznavati da uzrok problema može biti vezan za subjektivne faktore, kao što su pogrešna (iracionalna ili činjenično neutemeljena) uvjerenja vezana za objekte stavova koji su relevantni za uspjeh u obrazovanju ili pogrešan sistem vrijednosti koji 
koristimo da ocjenjujemo osobine tog objekta, a oklijevati da se ti subjektivni faktori (posebno vrijednosti) pokušaju promijeniti. ${ }^{2}$ Kada se kod određene (sub)populacije studenata ili učenika pokaže da, bez obzira na odgovoran pristup obrazovne institucije i njenih nastavnika svojim zadacima i njihovu kompetentnost, postoji negativan odnos prema nastavi i onom što je sa njom povezano, umjesto poduzimanja daljih koraka na unapređenju akademskog okruženja treba uvesti promjene u odgojnom pristupu, s ciljem mijenjanja načina na koji oni percipiraju i sistema vrijednosti po kojem vrednuju školu i obrazovanje, što ponegdje, nažalost, vjerovatno znači i uvođenje odgojne komponente u nastavu kao potpuno novog elementa. Ustvari, odgojna komponenta je uvijek prisutna u interakcijama studenti / učenici obrazovni sistem, samo je pitanje u kojem se smjeru odgojni proces odvija. Ukoliko je jedina vrsta prilagodbe koja se dešava prilagođavanje nastave i obrazovnog sistema studentima i učenicima s ciljem da se studenti više zainteresiraju za nastavu i motiviraju za učenje, a ako je ono po čemu studenti ocjenjuju ,interesantnost,, i ,relevantnost,, nastave i kvalitet rada nastavnika zasnovano (kako i jeste) na njihovom sistemu vrijednosti, onda studenti i učenici postaju odgajatelji a nastavnici i čitav obrazovni sistem predmet (pre)odgoja, jer se vrijednosti na osnovu kojih studenti ocjenjuju i vrednuju nastavu i obrazovanje uzimaju kao datost koju ne treba dirati i mijenjati, a stavovi studenata prema obrazovanju se pokušavaju popraviti mijenjanjem obrazovnog sistema kako bi oni taj sistem više vrednovali. Drugim riječima, studentski sistem vrijednosti postaje referentni okvir, nastava se prilagođava tom referentnom okviru, čime se implicitno prihvata njegova validnost, ili mu se čak pripisuje veća validnost od sistema vrijednosti na kojem je taj sistem postavljen. Na taj način, transfer vrijednosti, barem u jednoj mjeri, dešava se u smjeru studenti - obrazovni sistem, a ne obrnuto; možemo reći da dolazi do inverzije vrijednosnog transfera u kojoj nastavnici (i ne samo oni) prestaju biti odgajatelji i postaju oni koji bivaju odgajani. Transfer u ovom smjeru nije sporan ukoliko sadržaj samog transfera nije sporan; u suprotnom, taj je smjer potrebno obrnuti a sadržaj transfera promijeniti. ${ }^{3}$ Principi kognitivne terapije u tom slučaju mogu biti od koristi pri definiranju smjernica za promjenu

2 To oklijevanje se, između ostalog, može javiti, zbog onoga što Legrand (2001, str. 10) naziva „,tičkim kofuzionizmom, , , „mentalnom zbrkom,, zbog koje „više ne znamo što valja veličati, a šta osuđivati,,.

3 Kada bi obrazovni sistem svoj sistem vrijednosti zamijenio za onaj koji nije validan, onda bi de facto, kao kriterij svojih vrijednosti odbacio ono što bi trebao da promovira: znanje. Time bi sam sebe obesmislio i u akademskom aspektu, jer bi bilo apsurdno pokušavati prenijeti znanje a istovremeno na praktičnom primjeru pokazivati da znanje nije važno i da u praksi nije neophodno prema njemu postupati. 
sadržaja vrijednosnog transfera, dok tehnike mogu doprinijeti njegovoj većoj efikasnosti.

Kao što je prethodno naznačeno, stavovi imaju tri komponente, od kojih su prve dvije kognitivna, koja se tiče uvjerenja vezanih za objekat stava, i afektivna, koja je rezultat ocjene objekta stava. Ta ocjena nastaje „spajanjem,, uvjerenjâ i naših vrijednosti (Pennington, 2004) na osnovu kojih mi ocjenjujemo to što o objektu stava vjerujemo, što rezultira nastankom afektivne komponente stava. Iako je ovdje napravljena distinkcija između „uvjerenjâ,, i ,vrijednosti,,, vrijednosti su, u svojoj suštini, također uvjerenja ili koncepti. Razlika između „vrijednosti,, i ,uvjerenja,, koja čine kognitivnu komponentu stava jeste u tome što su vrijednosti koncepti odnosno uvjerenja koja se tiču poželjnosti i preferiranja određenih stanja ili ponašanja (Schwartz, 1992) dok, kada govorimo o uvjerenjima koja su dio kognitivne komponente stava, mislimo ili na ljudsku percepciju odnosa između dva aspekta objektivne stvarnosti ili na percepciju atributa nekog objekta koja je praćena određenim stepenom sigurnosti u ispravnost te percepcije (Šiber, 1998). Dakle, uvjerenja, u užem smislu riječi, tiču se osobina elemenata objektivne stvarnosti i njihovih međusobnih odnosa, dok se vrijednosti tiču poželjnosti određenih stanja i ponašanja. Procjena određenog odnosa između dva objekta ili procjena njihovih atributa vođena našim uvjerenjima o poželjnosti određenih stanja i(li) ponašanja uzrokuje i determinira naš emocionalni odnos prema tim objektima, i tako formira osnovu našeg stava prema njima. Ova činjenica (da su i vrijednosti, koje determiniraju prirodu stavova, po svojoj prirodi uvjerenja baš kao i kognitivna komponenta stava), od ključne je važnosti u kontekstu diskusije o mijenjanju stavova primjenom principa i tehnika kognitivne terapije.

\section{Kognitivna terapija i promjena obrazovno relevantnih stavova}

Termin kognitivna terapija je izvorno označavao vid terapije koji je razvio Aaron Beck 1960-ih godina namijenjen liječenju depresije (Beck, 2011; Beck, Rush, Shaw i Emery, 1979, prema Jakobsen, Hansen, Storebø, Simonsen i Gluud, 2011). Danas se kognitivna terapija koristi za tretman široke lepeze problema, dok se njen naziv upotrebljava skoro kao sinonim za termin „kognitivno-bihevioralna terapija,,, iako je taj termin sveobuhvatna oznaka koja uključuje različite vrste tretmana, od kojih su neki više bihevioralno a neki više kognitivno orijentisani, zbog čega bi, kako kaže Huppert (2009, str. 245) ,kognitivno-bihevioralnu terapiju (KBT) bilo bolje zvati kognitivne i bihevioralne terapije,,. 
Kognitivna terapija, odnosno kognitivni model na kojem je zasnovana, posmatra kognitivne aspekte psihičkog funkcioniranja kao osnovne determinante emocija i ponašanja (Friedman, Thase i Wright, 2008). Ovi „kognitivni aspekti,, imaju mnogo različitih imena, pri čemu je pojam uvjerenja najuopšteniji i obuhvata manje-više sve druge, uključujući i stavove, iako se među različitim vrstama uvjerenja prave određene razlike na osnovu njihove ,dubine, i snage uticaja na druga uvjerenja, te emocije i ponašanje (Beck, 2011). U „klasičnom,, terapijskom kontekstu, ovo kauzalno djelovanje kognitivnih aspekata u odnosu na emocije i ponašanja podrazumijeva da je promjena na kognitivnom nivou ključna za tretman određenog psihološkog problema (Clark, 1995, prema Longmore i Worrell, 2007). Kada je konkretno depresija u pitanju, osnovna pretpostavka kognitivne terapije je da osoba koja pati od depresije procesira informacije na pogrešan način, to procesiranje rezultira negativnim viđenjem sebe, budućnosti i svijeta, a sve to uzrokuje emocionalne, ponašajne i motivacijske simptome depresije (DeRubeis, Webb, Tang i Beck, 2010). Međutim, učenje o kauzalnom odnosu između uvjerenja, emocija i ponašanja koje je karakteristično za kognitivni model ne služi samo za objašnjenje psihopatologije već se radi o opštem modelu ponašanja, što omogućava da principi i tehnike koje kognitivna terapija koristi za tretman različitih oblika psihopatologije bude primijenjen i u svrhu promjene kognitivnih, a time i emocionalnih i ponašajnih elemenata koji se smatraju nepoželjnim ili neprihvatljivim, ali ne mogu biti okarakterizirani kao patološki. Kako su i stavovi jedan od oblika uvjerenja ${ }^{4}$ na čijoj promjeni se radi u okviru kognitivne terapije, primjenom kognitivnih tehnika bilo bi moguće djelovati na nepoželjne i neprihvatljive stavove koji nisu nužno odraz psihopatologije.

Osnovnoj premisi kognitivnog modela o kauzalnom djelovanju uvjerenja na emocije i ponašanja idu u prilog ranije citirana istraživanja o uticaju stavova na ponašanje, što važi i za istraživanja vezana za uticaj stavova prema obrazovanju na akademsko postignuće. Ova tvrdnja može biti formulirana i na nešto drugačiji način: kognitivni model i rezultati njegove kliničke primjene pokazuju opravdanost insistiranja na vezi između stavova i ponašanja i daju dodatnu potvrdu empirijskim nalazima o postojanju te veze. To ukazuje da je u naporima da se promijene ponašanja koja su relevantna za akademsko postignuće neophodno, u najmanju ruku, obratiti pažnju i na stavove te insistirati i raditi i na promjeni onih za koje se utvrdi da zaista jesu povezani

4 Stavovi su u kognitivnom modelu označeni kao uvjerenja vjerovatno zbog temeljne važnosti uvjerenja u konstituisanju stavova, iako oni, kao što je u ranijem opisu njihove strukture pokazano, imaju i emocionalnu komponentu. 
sa obrazovnim uspjehom. S obzirom na to da su i kognitivne komponente stavova i sistem vrijednosti zasnovani na uvjerenjima, u pokušajima promjene nepoželjnih stavova prema obrazovanju primjenom tehnika kognitivne terapije moguće je suočiti se sa četiri scenarija, odnosno četiri vrste stavova:

- stavovi u kojima ni vjerovanja koja se tiču nekih elemenata vanjske stvarnosti povezanih sa obrazovnim kontekstom i važnih za obrazovni uspjeh, ni vjerovanja koja su u osnovi sistema vrijednosti, a na osnovu kojih se ti elementi ocjenjuju, nisu ono što Šiber (1998) naziva zabludama, odnosno rezultat pogrešnih interpretacija i grešaka u zaključivanju, niti su činjenično neutemeljena, već su i u logičkom i u činjeničnom smislu validna;

- stavovi u kojima su vjerovanja vezana za objekt stava netačna (tj. radi se o zabludama) iako su uvjerenja na kojima se temelji sistem vrijednosti ispravna;

- stavovi u kojima je ono što se vjeruje o objektu stava tačno, ali uvjerenja na kojima se temelje vrijednosti na osnovu kojih se taj objekat stava ocjenjuje nisu;

- $\quad$ stavovi u kojima ni uvjerenja o objektu stava ni uvjerenja na kojima se temelje vrijednosti na osnovu kojih se taj objekat procjenjuje nisu tačna.

Rad na promjenama treba biti prisutan u svim situacijama osim prve, a može se pretpostaviti da bi za većinu nastavnika pitanje rada na mijenjanju vrijednosti učenika i studenata vjerovatno bilo veoma osjetljivo, posebno ako se radi o vrijednostima o čijoj ,neprihvatljivosti,, ne postoji društveni konsenzus. U svim oblicima terapije, ne samo u kognitivnoj, sličan problem se javlja u vidu pitanja vezanih za poštivanje autonomije klijenta i njegovog prava na vlastita uvjerenja, vrijednosti i individualnost uopšte, te prilagođavanja terapije njegovim individualnim karakteristikama s ciljem što boljeg provođenja terapijskog procesa. Svaki terapijski pravac ima određene strategije za rješavanje tih dilema i upravo te strategije mogu poslužiti za ilustraciju načina na koji bi se moglo postupati sa sličnim problemima u nastavnom procesu. U psihoterapijskoj praksi, smatra se da autonomija klijenta biva narušena ako se u tretmanu koristi modalitet koji nije kompatibilan sa njegovim vrijednostima (Hodge i Bushfield, 2006, prema Hodge, 2008). Pri tome treba naglasiti da je pojam vrijednosti usko vezan za kulturu; Branco i Valsiner (2012, xiii) čak smatraju da ,vrijednosti jesu kultura, a ne dio kulture. Govoriti o kulturnim vrijednostima jednako je precizno kao i govoriti o 'šećernom šećeru' i 'vodenoj vodi',.. Sposobnost terapeuta da uspješno 
radi sa klijentima koji su kulturno, a time i vrijednosno, različiti, naziva se „kulturna kompetentnost,, (Pantalone, Iwamasa i Martell, 2010).

Međutim, moguće su i situacije u kojima upravo vrijednosti karakteristične za određenu (sub)kulturu učestvuju u nastanku problema kojim se terapija bavi. Naprimjer, programi kognitivnog restrukturiranja usmjereni na promjenu problematičnog ponašanja u zatvorima usmjereni su i na, između ostalog, mijenjanje vrijednosti osoba sa kojima se radi (Lester i VanVoorhis, 2004, prema Lambert, Hogan, Barton i Stevenson, 2007). Okuda, Balán, Petry, Oquendo i Blanco (2009) navode primjer mijenjanja vrijednosnih uvjerenja kod osoba koje se bore sa problemom patološkog kockanja. Preciznije, radi se o uvjerenjima vezanim za poseban značaj i simboliku brojeva karakterističnim za određen broj kultura među kojima je i kultura Haitija, a koja su u slučaju opisanom u citiranom članku (koji se tiče klijentice porijeklom sa Haitija) morala biti promijenjena jer su imala velik uticaj na pokretanje i održavanje ponašanja vezanih za patološko kockanje. Kulturna kompetentnost u ovom slučaju izražena je ne neutralnim odnosom prema problematičnim uvjerenjima, već njihovom uspješnom promjenom na način koji nije direktno „napadao, ta uvjerenja već djelovao ,sporednim putevima,,, stvaranjem drugih, naizgled nepovezanih, uvjerenja koja su na kraju dovela do toga da se odustane od onih koja su bila predmet psihoterapijskog rada. Ukoliko je opravdano mijenjati disfunkcionalna, sa patologijom povezana vrijednosna uvjerenja u terapiji, čini se da ne postoji razlog zbog kojeg to isto ne bi bilo opravdano raditi kada su u pitanju vrijednosna uvjerenja koja opstruiraju razvijanje motivacije za učenje i produktivnog odnosa prema nastavi, bez obzira što negativan odnos prema takvim vrijednostima nije u potpunosti društveno prihvaćen. To posebno važi ako uzmemo u obzir da neuspjeh u obrazovanju može biti u određenoj mjeri povezan za mentalnim oboljenjima. Naprimjer, Stern (2012) navodi niz istraživanja (Archambault i sar., 2009, Card i sar., 1999, Robins i Ratcliff, 1980) koja pokazuju da su negativni stavovi i smanjeno učestvovanje u nastavi povezani sa odustajanjem od školovanja, a prestanak pohađanja škole povezan sa nizom negativnih posljedica, kao što su manje mogućnosti za zaradu i problemi vezani za mentalno zdravlje (npr. depresija i anksioznost).

Slične zaključke moguće je izvesti i kada je u pitanju fakultetsko obrazovanje ako se, naprimjer, uzme u obzir činjenica da je globalna ekonomija, prema procjenama iz 2003. godine, nametala standard prema kojem je šest od deset poslova zahtijevalo neki nivo poslijesrednješkolskog obrazovanja (Carnevale i Desrochers, 2003, prema Lotkowski, Robbin i Noeth, 2004) te da stabilnost 
zaposlenja predstavlja jedan od prediktora dobrog mentalnog zdravlja (WHO, 2011), iz čega slijedi da pogrešan odnos prema obrazovanju nakon srednje škole predstavlja faktor rizika za kasnije probleme sa mentalnim zdravljem i da rad na promjeni negativnih stavova vezanih za obrazovanje može djelovati preventivno na pojavu takvih problema. Izovih razloga mijenjanje vrijednosnih uvjerenja koja mogu negativno djelovati na odnos prema obrazovanju ne samo da je etički nesporno već se postavlja kao etički imperativ, a principi i tehnike kognitivne terapije se, zato što dolaze iz terapijskog konteksta, dodatno potvrđuju kao pogodan alat za njihovu promjenu.

\section{Prijedlog integracije principa i tehnika kognitivne terapije u nastavni proces}

Sam nastavni proces predstavlja izuzetno pogodan teren za primjenu principa i tehnika kognitivne terapije u promjeni negativnih obrazovno relevantnih stavova studenata, prije svega zbog prisustva studenata na jednom mjestu, odnosno mogućnosti da se na veći broj njih pokuša djelovati istovremeno. Međutim, problem može predstavljati činjenica da nastavnici nisu kognitivni terapeuti, i da nisu svi u jednakoj mjeri zainteresovani za odgojni rad sa studentima. Stoga bi uspješan model primjene morao uključivati prije svega nastavnike koji žele (uspješnije) odgojno djelovati, i biti adekvatno pripremljen u dvije faze:

1) identificiranje $i$ opis obrazovno relevantnih stavova, vrijednosti i uvjerenja koje je neophodno promijeniti i

2) obuka nastavnika za razumijevanje ponašanja studenata u skladu sa postavkama kognitivnog modela i primjenu odgovarajućih tehnika kognitivne terapije u nastavnom kontekstu.

Prva faza se sastoji iz većeg broja koraka:

- dobijanje pregleda studentskih stavova prema fakultetu, nastavnicima i predmetima

- utvrđivanje sociodemografskih karakteristika studenata

- identificiranje pojedinačnih stavova koji bi mogli / trebali biti povezani sa načinom na koji se studenti odnose prema nastavi, tj. koji zaista utiču na njihovo ponašanje

- identificiranje stavova koji uzrokuju da je taj odnos negativan

- identificiranje uvjerenja o objektima obrazovno relevantnih nepoželjnih stavova (tj. otkriti sadržaj njihove kognitivne komponente) i utvrditi njihovu činjeničnu i racionalnu utemeljenost 
- identificiranje uvjerenja na kojima se temelje vrijednosti na osnovu kojih nastaju obrazovno relevantni nepoželjni stavovi

- ukoliko se radi o uvjerenjima koja nisu racionalna ili činjenično zasnovana, utvrditi način na koji oni koji ih prihvataju kao istinita „dokazuju, njihovu istinitost

- utvrditi obrasce povezanosti sociodemografskih karakteristika povezane sa razlikama u prihvatanju određenih stavova, uvjerenja i vrijednosti

U provođenju i prve i druge faze ključnu ulogu bi trebao imati kognitivni terapeut, s tim što bi u prvoj fazi, u svrhu provjere stavova vezanih za školu i nastavnike i njihovog tumačenja, vjerovatno trebao biti uključen i edukacijski psiholog. Ključ za uspješno provođenje prve faze jeste ispravan izbor i primjena odgovarajućih tehnika i instrumenata za identificiranje stavova i njihovih relevantnih karakteristika, pri čemu treba koristiti i instrumente koji se koriste u socijalnopsihološkim istraživanjima stavova, ali i tehnike koje se koriste pri uvodnoj procjeni i u okviru konceptualizacije problema u okviru kognitivne terapije. Za sam pregled stavova prema školi, nastavnicima i časovima, u ovakvom kontekstu, moguće je, naprimjer, primijeniti prilagođenu Reviziju pregleda procjene stavova prema školi, instrumenta koji su razvili McCoach i Siegle (2003b), ili prilagoditi neki drugi instrument, ili razviti novi.

U svakom slučaju, rezultati dobijeni primjenom ovog instrumenta poslužili bi samo kao polazna tačka za dalju analizu, koja bi mogla biti nastavljena u razgovoru kognitivnog terapeuta sa pojedinim studentima. Taj razgovor bi najviše ličio na uvodnu procjenu u okviru kognitivnog tretamana. U fazi procjene u okviru kognitivne terapije, terapeut, između ostalog, želi saznati određene sociodemografske činjenice o klijentu, želi dobiti saznanja o njegovim vrijednostima, svakodnevnom funkcioniranju i načinu na koji poremećaj koji treba biti predmet tretmana utiče na to funkcioniranje (Beck, 2011). U razgovoru koji bi terapeut vodio sa studentom, cilj bi bio prije svega potvrditi postojanje stavova identificiranih upitnikom te utvrditi sociodemografske činjenice o svakom studentu. Zatim, neophodno bi bilo ući u detaljniju analizu identificiranih negativnih stavova i pokušati dokučiti kakve osobine studenti pripisuju objektima (fakultetu, profesorima, časovima) negativnih stavova te po kojem kriteriju odnosno prema kojoj vrijednosti ili vrijednostima ocjenjuju osobine tih objekata. Također, važno je utvrditi koji se stavovi aktiviraju pri susretima (stvarnim ili mentalnim) sa objektom nekog od stavova, kakve to emocije i razmišljanja inicira i kako te emocije utiču na ponašanje studenta. Emocije i misli koje se u određenoj situaciji 
javljaju pomažu u identificiranju stavova pod čijim uticajem oni nastaju, a identificiranjem stavova moguće je doprijeti do dubljih struktura, uključujući i vrijednosti, na osnovu kojih su stavovi nastali.

Ovakav pristup slijedi hijerarhiju kognitivnih struktura onako kako je ona pretpostavljena u okviru kognitivnog modela: najvažnija, najuticajnija uvjerenja su tzv. sržna uvjerenja (eng. core beliefs) i njih karakterizira to što su suviše generalizirana i rigidna; sržna uvjerenja utiču na nastanak srednjih (intermediate) uvjerenja, koja se dijele u tri veće kategorije: pravila, stavovi i pretpostavke. ${ }^{5}$ Nakon sržnih i srednjih uvjerenja, najpovršniji nivo misaonog funkcioniranja predstavljaju automatske misli i emocije. One su specifične za pojedine situacije; tačnije, dublja uvjerenja, kao što su stavovi, utiču na način na koji pojedinac percipira određenu situaciju, i automatske misli su izraz te percepcije. Nakon što se pojave, ove automatske misli utiču na emocionalne, ponašajne i fiziološke reakcije; međutim, kako su te misli samo manifestacija dubljih uvjerenja, mijenjanje njih bi bio samo početak mijenjanja dubljih struktura, prije svega sržnih uvjerenja, jer je jedino tako moguće postići dugotrajniju promjenu (ibidem), pri čemu ne treba zanemariti važnost osporavanja i mijenjanja tih automatskih misli kao takvih zbog činjenice da su one ipak te koje utiču na to kako se neko trenutačno osjeća i ponaša. Krajnji cilj ovog razgovora bi bio napraviti tzv. kognitivnu konceptualizaciju vezanu za pojedine stavove svakog ispitivanog studenta, odnosno dobijanje okvirne sliku o tome kako se (kroz koje automatske misli i emocije) ti stavovi manifestiraju u pojedinim situacijama važnim za obrazovanje i kakva im je kognitivna struktura i osnova.

Od ključne važnosti bi u okviru „kognitivne konceptualizacije,, bilo pokušati ispitati zašto studenti prihvataju ona uvjerenja koja prihvataju (bez obzira na njihovu vrstu i „dubinu,,), kako ih opravdavaju i dokazuju, i da li ih uopšte prihvataju na osnovu nekih dokaza ili su ta uvjerenja usvojili samo ili uglavnom kroz socijalno uvjetovanje. Format nestrukturiranog ili polustrukturiranog intervjua pogodan je upravo za vršenje takve jedne

5 Ispravno je, čini se, zaključiti da bi, ako stavovi prema kognitivnom modelu nastaju na osnovu sržnih uvjerenja, vrijednosna i/ili atributivna uvjerenja za koja socijalnopsihološko viđenje stavova tvrdi da učestvuju u produkciji stavova trebala u hijerarhiji kognitivnog modela biti označena kao sržna uvjerenja. Ova sinteza socijalnopsihološkog poimanja stavova i razumijevanja stavova u kognitivnom modelu moguća je vjerovatno samo kod onih stavova za koje su socijalnopsihološka istraživanja utvrdila da imaju uticaja na ponašanje, odnosno koji imaju visoku prediktivnu vrijednost, jer se kognitivna terapija, odnosno kognitivni model, bavi prije svega uvjerenjima koja imaju opipljive (negativne) posljedice na emocije i ponašanje ljudi. To, s druge strane, znači da stavovi o kojima se govori u kognitivnoj terapiji vjerovatno imaju karakteristike, ili neke od karakteristika (dostupnost, dosljednost, stabilnost, povezanost sa specifičnom ponašanjem, itd.), koje prema socijalnim psiholozima stav treba imati da bi mogao uticati na ponašanje. 
provjere. U ovoj prvoj fazi neophodno je uraditi najmanje još dvije stvari: identificirati frekvenciju svih stavova, vrijednosti i uvjerenja koje bi trebalo mijenjati i ispitati postojanje korelacija između pojedinih sociodemografskih karakteristika i pojedinih stavova, vrijednosti i uvjerenja, posebno onih najzastupljenijih. Frekvenciju javljanja pojedinih stavova neophodno je utvrditi prije svega da bi se znalo mijenjanju kojih od njih treba dati prioritet, tj. da bi se u pripremi strategije mijenjanja počelo sa onim što će djelovati na najveći broj studenata. Vezu između pojedinih uvjerenja i sociodemografskih indikatora, posebno materijalnog statusa, treba tražiti da bi se postavile što bolje hipoteze o etiologiji određenih uvjerenja i vrijednosti, odnosno kontekstu u kojem su nastajala, što također treba da da dodatni kvalitet i dubinu strategiji mijenjanja onih koje je potrebno promijeniti. Postoje valjani razlozi za pretpostavku da će utvrđene razlike u pogledu materijalnog statusa biti dobar prediktor razlika u stavovima, uvjerenjima i vrijednostima među studentima. James (2001) je istražujući razloge manjeg učešća Australaca koji žive u ruralnim ili izoliranim područjima $\mathrm{u}$ visokom obrazovanju zaključio da su socioekonomski status te društveni i kulturni kontekst bolji prediktori neučešća u visokom obrazovanju od fizičke udaljenosti tih osoba od univerzitetskih kampusa. Međutim, čak i kada se upišu na fakultet, za studente nižeg socioekonomskog statusa postoji manja vjerovatnoća da će završiti sve četiri godine i dostići stepen bakalaureata (Walpole, 2003).

Jedno objašnjenje načina na koji socioekonomski status, vrijednosti i stavovi te obrazovni uspjeh mogu biti povezani ponudio je francuski sociolog Pierre Bourdieu, uvodeći (odnosno oživljavajući) pojam habitusa. Prema Bourdieuu, habitus predstavlja ,sistem shema percepcije i razlikovanja utjelovljen u vidu dispozicija koji odražava čitavu historiju grupe, stečen kroz formativna iskustva iz djetinjstva. Strukturalni kod kulture upisuje se kao habitus i uzrokuje proizvodnju društvene prakse" (Nash, 1999, str. 177); ove sheme se javljaju kao „formalne i neformalne norme, običaji i pravila društva,, (Nash, 1990, str. 433). Može još biti definiran kao „internalizirani skup trajućih dispozicija i strukturiranih sklonosti u mišljenju, osjećanju i ponašanju,, (Throop i Murphy, 2002, str. 187), ono što generira percepcije i stavove (Thompson, 1991, prema Throop i Murphy, 2002). Kao takav, habitus determinira razumijevanje prikladnih odgovora u različitim situacijama (Wolpe, 2003). Struktura koja oblikuje habitus kao sistem kognitivnih i motivacijskih struktura prema Bordieuu (Bordieu, 1977, prema Throop i Murphy, 2002) ne podrazumijeva ništa drugo nego klasno specifične materijalne uslove postojanja. U kontekstu obrazovanja, činjenica da habitus 
nastaje pod uticajem klasne pripadnosti (zato što ona djelomično determinira strukturalni kod kulture kojem pojedinac može biti izložen) može značiti da će habitus osobe slabijeg socioekonomskog statusa činiti takvu osobu sklonijom da ima niže aspiracije, da koristi lošije obrazovne strategije te pravi izbore koji mogu rezultirati produžavanjem njenog lošijeg socioekonomskog položaja (Walpole, 2003). Unatoč primjetnom determinističkom ozračju u kojem je pojam habitusa situiran, on može biti promijenjen usvajanjem i dodavanjem novih elemenata usljed, u najširem smislu kazano, sticanja novih iskustava (ibidem), što može djelomično objasniti razloge zbog kojih svi pripadnici jedne socioekonomske grupe ne postižu nužno iste obrazovne rezultate. Zaključak koji se na osnovu navedenog može izvesti jeste da je neophodno znati nešto o socioekonomskom statusu pojedinca da bi se bolje razumjeli njegovi stavovi i način razmišljanja, te da efekat koji socioekonomski status ima na te karakteristike, a koji je utjelovljen u habitusu, nije nepromjenjiv.

Druga faza bi imala za cilj pripremiti nastavnika za primjenu odgovarajućih tehnika kognitivne terapije $\mathrm{u}$ okviru nastavnog procesa na način koji je prilagođen tom kontekstu i saznanjima dobijenim u toku prve faze. U kognitivno-bihevioralnoj terapiji klijenti se podučavaju da identificiraju i adekvatno odgovore na svoje disfunkcionalne misli korištenjem (između ostalog),,vođenog otkrivanja,, čiji je najvažniji element sokratovsko ispitivanje (Beck, 2011). Činjenica da su koncepti ,,vođenog otkrivanja,, i ,sokratovskog ispitivanja, , prisutni u kognitivnoj terapiji čini je još pogodnijom za primjenu u obrazovnom procesu jer su oni, kao metode podučavanja, također prisutni i u edukacijskoj psihologiji odnosno pedagogiji / andragogiji. „Vođeno otkrivanje,, koristi se kao metod podučavanja rješavanja problema, gdje se onom kojeg se podučava daje dovoljno uputa da bi se osiguralo da će shvatiti pravilo, princip ili koncept kojemu treba biti podučen, ali se istovremeno daje dovoljno slobode da bi mogao organizirati i integrirati ono što već postoji u njegovom dugoročnom pamćenju sa onim što uči (Mayer i Wittrock, 2006). Sokratovsko ispitivanje, ili sokratovski dijalog, kojim se teži navesti učesnike dijaloga da preispitaju istinitost vlastitih uvjerenja u pokušaju da odgovore na neko pitanje koje su sami izabrali, svoju je primjenu u obrazovanju našao već 1920-ih godina, kroz teoriju i radove njemačkog filozofa Leonarda Nelsona (Van Rossem, 2006). Najvažniji (iako ne nužno i jedini) cilj primjene sokratovskog metoda u obrazovnom procesu jeste podučavanje učenika kritičkom mišljenju kroz pažljivo razmatranje ideja i problema (Boghossian, 2003). Whiteley (2006) daje sažeti prikaz primjene sokratovskog metoda:

Osnovni pristup sastoji se iz toga da se prvo postavi uopšteno pitanje, 
obično u obliku „Šta je...?,, pitanja, na koje sagovornik (tj. učesnik u dijalogu) odgovara (npr. daje definiciju), a na koje onaj koji postavlja pitanje može odgovoriti ukazujući na neadekvatnost sagovornikovog odgovora [npr. „suviše uzak, previše ograničen, pristran ili ne uzima u obzir neke činjenice, , Lavine, 1984, str. 22] (Lavine, 1984). Kroz ovaj proces dijaloga, početni odgovor (npr. definicija) biva uništen ( $\mathrm{tj}$. pokazuje se da je neadekvatan), i zahtijevaju se od sagovornika dalje razmišljanje i analiza, što ga navodi da dâ novi odgovor (Lavine, 1984). Ispitivanje se nastavlja, često korištenjem „tehnike suprotnog primjera,, (tj. razmatranjem dodatnih primjera, slučajeva, i/ili pojedinosti) (Lavine, 1984, str. 23), s krajnjim ciljem dobijanja adekvatnog odgovora, ukoliko je to moguće. Sokratovski pristup se koristi da bi se nekog navelo da preispita ono u šta vjeruje; ne koristi se u svrhu prezentiranja gotovih informacija (Magee, 2001, str. 66).

Ovdje treba naglasiti da je sokratovski dijalog samo najpopularniji, ali ne i jedini oblik sokratovskog metoda (Van Rossem, 2006). Također, kognitivna terapija nije jedini oblik terapije koji koristi sokratovski metod, te i u ovom (terapijskom) kontekstu sokratovsko ili sistematsko ispitivanje predstavlja samo najčešće korištenu, ali ne i jedinu, komponentu sokratovskog metoda (Overholser, 1993). Slično njegovoj izvornoj filozofskoj namjeni i standardnoj pedagoškoj / andragoškoj primjeni, cilj upotrebe sistematskog ispitivanja u psihoterapiji je, upotrebom stepenovanih pitanja, poboljšati nezavisno i racionalno mišljenje klijenata i oblikovati njihov misaoni proces (ibidem), te omogućava da se klijenti poduče identificiranju i ispravljanju razmišljanja koja nisu racionalna (Seeskin, 1987, prema Overholser, 1993). Bez obzira što sokratovsko ispitivanje nije jedina tehnika koja se koristi u KBT niti je jedina komponenta sokratovske metode, ipak je vjerovatno najpogodnija za kontekst nastave jer ne zahtijeva nikakva dodatna pomagala, ništa osim sposobnosti nastavnika da je uspješno primjenjuje. S obzirom da bi nastavnici trebali već imati određeni nivo pedagoške naobrazbe, a da je sokratovsko ispitivanje već odavno dio pedagoške teorije i prakse, trebalo bi očekivati da su upoznati barem sa osnovama tog metoda, što bi im trebalo olakšati potpunije savladavanje njegove primjene. Ono što bi u kontekstu pokušaja da se promijene stavovi bilo potpuno novo nije, stoga, korišteni metod već sadržaj koji se želi objasniti i razjasniti, i vjerovatno bi izazovniji dio ove obuke bilo objašnjavanje osnovnih koncepata kognitivnog modela i objašnjavanje unutrašnje psihološke strukture pojedinih stavova studenata, što bi vjerovatno bio veći izazov što je predmet koji nastavnik predaje po svom sadržaju „udaljeniji,, od psihologije. 
Osim što bi im pomoglo u savladavanju primjene sokratovskog ispitivanja u svrhu mijenjanja stavova prema obrazovanju, eventualno prethodno poznavanje i korištenje sokratovskog metoda u nastavi učinili bi cijeli pokušaj promjene stavova spontanijim i prirodnijim, u smislu da način na koji bi nastavnik raspravljao o uvjerenjima studenata za njih ne bi bio nov i neobičan i ne bi izazivao sumnjičavost $i$, eventualno, otpor prema saradnji sa nastavnikom i učešću u dijalogu. To bi posebno bio slučaj onda kada bi diskusija o stavovima sadržajno bila dobro uklopljena i povezana sa gradivom koje se predaje. S druge strane, ukoliko nastavnik nije prethodno dobro vladao upotrebom sokratovskog metoda, obuka za njegovo korištenje u svrhu mijenjanja stavova omogućit će mu da stečeno znanje i vještine prenese $i$ upotrijebi u svrhu objašnjavanja onoga što jeste sadržaj predmeta koji predaje i tako unaprijedi svoje nastavničke i predavačke vještine, poveća kvalitet svojih časova i predmet koji predaje predstavi na zanimljiviji način. Na taj način bi se, također, doprinijelo unapređenju stavova studenata, relevantnih za njihov obrazovni uspjeh, ali ovaj put uklanjanjem stvarnih nedostataka vezanih za objekte tih stavova ili poboljšavanjem njihovih karakteristika.

Podučavanje nastavnika osnovama kognitivnog modela i konkretnim saznanjima vezanim za strukturu i genezu stavova studenata dobijenih u prvoj fazi omogućit će im da vještinu sokratovskog ispitivanja koriste usmjerenije i efikasnije; naučiće kako da (naprimjer, postavljanjem kojeg pitanja) aktiviraju pojavljivanje automatskih misli koje su povezane sa stavovima koji se žele promijeniti te kako da identificiraju te misli u riječima studenata u toku rasprave. Također, unaprijed će biti upoznati sa načinom na koji se takve automatske misli argumentiraju (tj. racionaliziraju) i kako su povezane sa uvjerenjima koja su dublje usađena; to bi trebalo olakšati efikasnu upotrebu sokratovskog ispitivanja, odnosno davanje kontraargumenata i osporavanje automatskih misli, jer bi se dio argumenata za to osporavanje mogao unaprijed pripremiti, te, kroz unaprijed pripremljenu (okvirnu) seriju pitanja, olakšati navođenje studenata da uvide vezu između automatskih misli sa dubljim uvjerenjima i tako postanu svjesni tih dubljih uvjerenja. Nakon što (odnosno ako) bi dublja uvjerenja bila osviještena, moglo bi se (opet, sa već dobro pripremljenim argumentima i pitanjima) preći na njihovo osporavanje i dekonstrukciju, i tako nastaviti dok se ne bi došlo do sržnih uvjerenja (naravno, ukoliko bi to bilo potrebno) i njih osvijestilo, time stvarajući pretpostavke i za njihovo osporavanje. S obzirom da nastavnici rade sa grupama studenata, prioritet bi trebalo dati stavovima koji su najzastupljeniji u datoj studentskoj populaciji, ali bi, u skladu sa kontekstom, trebalo započinjati diskusije i o onim koji su manje zastupljeni. 
U obje ove situacije (pri problematiziranju stavova koje dijeli većina i pri raspravi o onima koje dijele pojedinci ili manjina) raspravu je moguće voditi na tri načina: diskusijama sa pojedinačnim studentima, moderiranjem diskusije između studenata te samostalnom nastavnikovom razradom argumenata za određeni stav i protiv njega. Također, u obje situacije svako problematiziranje stava koji je prisutan kod većeg ili manjeg broja studenata u cilju njegovog uklanjanja može preventivno djelovati na one studente koji taj stav nemaju, odnosno inokulirati ih protiv eventualnog prihvatanja takvih stavova nekada $u$ budućnosti. Promjena stavova i inokulacija mogu biti olakšani ukoliko posebna pažnja bude posvećena mijenjanju stavova pojedinaca koji imaju uticaja među studentima i koji mogu uticati na to da oni promijene svoja uvjerenja. Takvi pojedinci mogu biti identificirani primjenom sociometrijskog postupka, te im može biti posvećena posebna pažnja u diskusijama u toku nastave, tako što će se, naprimjer, namjerno inicirati pojedinačne diskusije sa njima. Osim diskusije u toku nastave, kognitivni terapeut može izvan nastavnog konteksta održavati razgovore sa takvim pojedincima i detaljnije se posvetiti promjeni njihovih stavova i time povećati šanse da oni facilitiraju promjenu mišljenja kod kolega kod kojih imaju uticaja. Proces primjene naučenog od strane nastavnika u početku može pratiti kognitivni terapeut prisustvujući nastavi, a nakon što bi se uvjerio da je nastavnik dovoljno dobro savladao relevantni sadržaj i tehnike, analizu njegovog rada bi mogao svesti na oblik i frekvenciju uobičajene kliničke supervizije. Na ovaj način, obuka jednog nastavnika bi se vršila samo jednom a njegove vještine kasnije, kroz „,superviziju,, samo dodatno usavršavale. Te vještine nastavnik bi mogao koristiti u nastavi iz bilo kog predmeta i, u osnovi, u bilo kojoj vrsti interakcije sa studentima, s tim što bi za svaki novi predmet i svaku novu studentsku populaciju trebala biti urađena nova priprema; nastavnici koji bi pokazali visok interes za ovakvu vrstu rada mogli bi se podučiti da dio pripreme implementiraju sami.

\section{Zaključak}

Uzmemo li sve relevantne činjenice u obzir, nije teško zaključiti da se od dobro pripremljene i isplanirane primjene tehnika kognitivne terapije $\mathrm{u}$ svrhu promjene nepoželjnih stavova vezanih za različite aspekte obrazovanja može očekivati da poluči željene rezultate. Kognitivna terapija odnosno njeni principi i tehnike prilagođene obrazovnom kontekstu mogu unaprijediti odgojnu (ali i „,̌isto,, obrazovnu) komponentu nastave, i tako joj pomoći da potpunije ispuni vlastite ciljeve, tim prije što se čini da imaju kapacitete za prevazilaženje posljedica koje određeni objektivni faktori, kao što su 
socioekonomske razlike, mogu imati na obrazovni uspjeh studenata zbog snažnog uticaja koji imaju na njihovu percepciju i odnos prema obrazovanju.

Ono što može djelovati iznenađujuće jeste broj mogućih pozitivnih posljedica te primjene, koje ne moraju biti nužno predviđene izvornim planom. Naprimjer, čak i ako kod jednog broja studenata ne bi bio postignut uspjeh u promjeni stavova, činjenica da bi kod druge grupe bio postignut uspjeh značila bi da je socijalna podrška za nepoželjne stavova umanjenja, što bi kod onih koji te stavove još uvijek budu prihvatali rezultiralo ne nužno njihovim odbacivanjem, ali vjerovatno manjim stepenom sigurnosti u njihovu ispravnost, a zbog toga i smanjenjem uticaja koji ti stavovi imaju na ponašanje. Također, odgojna komponenta ovakvog djelovanja vjerovatno se ne bi sastojala samo u dekonstrukciji i uklanjanju nepoželjnih vrijednosnih uvjerenja, već bi traženje od studenata da validnost svojih uvjerenja mjere na osnovu njihove logičnosti i zasnovanosti na činjenicama impliciralo da su racionalnost i utemeljenost na činjenicama važnije osobine njihovih uvjerenja od nekih drugih razloga zbog kojih ih možda prihvataju, odnosno da su to vrijednosti koje trebaju prihvatiti i njegovati kada je u pitanju izbor onoga u šta će vjerovati. Osim vrijednosne promjene, insistiranje na racionalnosti i činjeničnoj utemeljenosti uvjerenja te jačanje sposobnosti studenata da analiziraju vlastita uvjerenja i njihove veze sa svojim osjećajima i ponašanjima, može na još jedan način (osim kroz sprečavanje nezaposlenosti i siromaštva) doprinijeti prevenciji pojave problema sa mentalnim zdravljem, tako što će im olakšati da razumiju sva druga svoja uvjerenja i uklone ona koja nisu racionalna, odnosno ona koja mogu biti svrstana u kategoriju zabluda, a koja zbog svoje iracionalnosti i neutemeljenosti mogu imati negativne posljedice po njih. Ustvari, može se reći da bi upoznavanje sa principima i tehnikama kognitivne terapije studentima omogućilo da steknu veću kontrolu nad vlastitim duševnim životom i ponašanjem uopšte (a time i da povećaju samopuzdanje), te da u najširem smislu riječi preuzmu veću odgovornost za sebe i svoje postupke.

Kada su u pitanju nastavnici, osim što mogu steći vrijedne vještine i postati efikasniji predavači i odgajatelji, oni će također dobiti razloge da preispitaju vlastite stavove i da usvoje racionalnost $\mathrm{i}$ činjeničnu zasnovanost uvjerenja kao vrijednosti u tom domenu. Pored koristi koje u tom procesu mogu ostvariti za sebe, vrijednosna promjena trebat će se desiti ukoliko nastavnik želi efikasno djelovati na studente, jer je teško očekivati da studenti prihvate vrijednosti koje nastavnik na njih želi prenijeti ukoliko on(a) sam(a) te vrijednosti ne njeguje. Također, možda više nego kod studenata, treba očekivati da nastavnici 
osnaže sposobnost nadziranja i održavanja vlastitog mentalnog zdravlja, zato jer su oni ti koji bi znanje o principima i tehnikama kognitivne terapije trebali dobiti direktno od stručnjaka za kognitivnu terapiju, za razliku od studenata koji to znanje ne dobijaju ,iz prve ruke,.. Dodatna razlika u korist nastavnika jeste to što će nastavnik koji prihvati ovakav odgojni pristup nastaviti, susrećući se uvijek sa novim populacijama studenata, usavršavati svoje vještine samoanalize i kritičkog mišljenja a time i povećavati mogućnosti unapređenja vlastitog mentalnog zdravlja. Još jedan od plodova praktikovanja kognitivne samoanalize bile bi i bolje socijalne vještine jer bi razumijevanje uzroka vlastitog ponašanja omogućilo da se bolje razumiju i uzroci ponašanja drugih, čime bi se olakšalo izbjegavanje konflikata koji nastaju kao rezultat nesporazuma i pogrešnih interpretacija ponašanja drugih. Na taj način, odnosi unutar studentske populacije i odnosi te populacije sa nastavnikom bili bi poboljšani, što bi vrlo vjerovatno rezultiralo boljom percepcijom na obje strane, većom motivacijom za saradnju, kvalitetnijom saradnjom, te boljim obrazovnim uspjehom studenata.

Povećanje motivacije, a time i obrazovnog uspjeha, bili bi s druge strane posljedice i primarnog rezultata primjene kognitivne terapije unastavi, odsustva negativnih stavova kod studentata. Veći obrazovni uspjeh bi vjerovatno doveo do veće samoefikasnosti, koja bi tu motivaciju dodatno povećala i time dodatno pozitivno djelovala na obrazovni uspjeh. Promjena odnosa studenata prema nastavi koja bi se desila kao rezultat djelovanja nastavnika te njihov bolji obrazovni uspjeh, do kojeg bi došlo usljed te promjene, usljed boljeg odnosa sa nastavnikom i usljed upotrebe sokratovskog metoda od strane nastavnika u sklopu podučavanja gradiva, trebali bi povećati samoefikasnost kod nastavnika (dakle, njegova percepcija sebe kao predavača i odgajatelja bi se trebala popraviti), a time i njegovu motivaciju za rad i kvalitet njegovog rada, što bi se, opet, ogledalo u većem obrazovnom uspjehu studenata. Sve navedene posljedice (kao i druge koje su zamislive a nisu navedene) samo su moguće, ne i nužne, ali se ipak čine dovoljno vjerovatnim da opravdaju barem pokušaj primjene kognitivne terapije i njenih principa u odgojnom i akademskom djelovanju nastavnika. 


\title{
TRAINING OF UNIVERSITY TEACHERS FOR MORE EFFICIENT EDUCATIONAL WORK THROUGH USAGE OF PRINCIPLES OF COGNITIVE BEHAVIOURAL THERAPY
}

\begin{abstract}
- Abstract -
Attitudes of students towards education represent one of the most important determinants of their motivation for learning and academic success. Possession of tools for modification of those attitudes, when they prevent academic participation and success, would simplify the rearing and teaching role of teachers. Since cognitive therapy is highly efficient approach of changing behaviour by changing beliefs (including attitudes), the adaption of its basic principles and techniques in education context regarding modification of relevant attitudes, as well as education of teachers in the field of cognitionbased techniques, could satisfy the need for such a tool. Here we present the theoretical elaboration of possibilities to integrate the principles and techniques of cognitive therapy into educational process in order to facilitate change of attitudes which can inconveniently affect academic inclusion and success of students.
\end{abstract}

Keywords: attitudes towards education, academic success, cognitive model, Socratic method. 


\section{Literatura}

- Ajayi, K. O., Lawani, A. O. i Salomi, M. O. (2012). The Influences of Self-Concept and Academic Motivation on Students' Attitude to Mathematics in Selected. Secondary Schools in Ogun State, Nigeria. European Journal of Scientific Research, 67(3), 444-455.

- Baumeister, R. F. i Bushman, B. J. (2008). Social Psychology and Human Nature. Belmont: Thomson Wadsworth.

- Beck, J. S. (2011). Cognitive Behavior Therapy: Basics and Beyond (2nd ed.). New York: The Guilford Press.

- Benford, R. i Gess-Newsome, J. (2006). Factors Affecting Student Academic Success in Gateway Courses at Northern Arizona University. Pristupljeno na stranici Northern Arizona University, Center for Science Teaching and Learning: http://www2.nau. edu/ facdev-p/TR/Factors.pdf.

- Boghossian, P. (2003). How Socratic Pedagogy Works. Informal Logic, 23(2), 17-25.

- Nash, R. (1999). Bourdieu, 'Habitus', and Educational Research: Is It All Worth the Candle? British Journal of Sociology of Education, 20(2), 175-187.

- Nash, R. (1990). Bourdieu on Education and Social and Cultural Reproduction. British Journal of Sociology of Education, 11(4), 431-447.

- Branco, A. U. i Valsiner, J. (2012). Editor's Introduction: Values as Culture in Self and Society. In Branco, A. U. i Valsiner, J. (Eds.), Cultural Psychology of Human Values (pp. vii - 2). Charlotte, NC: Information Age Publishing.

- Curtis, K. M. (2006). Improving Student Attitudes: a Study of a Mathematics Curriculum Innovation. PhD Thesis. Kansas State University, Manhattan.

- DeRubeis, R. J., Webb, C. A., Tang, T. Z i Beck, A. T. (2010). Cognitive Therapy. In Dobson, K. S. (Ed.), Handbook of Cognitive - Behavioral Therapies (3rd ed.). (pp. 277-316). New York: The Guilford Press.

- Friedman, E. S., Thase, M. E. i Wright, J. H. (2008). Cognitive and Behavioral Therapies. In Tasman, A., Kay, J., Lieberman, J. A., First, M. B. i Maj, M. (Eds.). Psychiatry (3rd ed.) (pp. 1920-1947). New Jersey: John Wiley i Sons.

- Haslett, B. J. (1976). Attitudes Toward Teachers as a Function of 
Student Academic Self-Concept. Research in Higher Education, 42, 41-58.

- Hewstone, M., Stroebe, W. i Jonas, K. (2012). An Introduction To Social Psychology (5th ed.). Chichester: John Wiley i Sons.

- Hodge, D. R. (2008). Constructing spiritually modified interventions: Cognitive therapy with diverse populations. International Social Work, 51, 178-192.

- Huppert, J. D. (2009). The Building Blocks of Treatment in Cognitive-Behavioral Therapy. The Israeli Journal of Psychiatry and Related Sciences 46(4), 245-250.

- Jakobsen, J. C., Hansen, J. L., Storebø, O. J., Simonsen, E. i Gluud, C. (2011). The Effects of Cognitive Therapy versus 'No Intervention' for Major Depressive Disorder. PLoS ONE, 6(12), 1-11.

- James, R. (2001). Participation disadvantage in Australian higher education: An analysis of some effects of geographical location and socioeconomic status. Higher Education 42(4), 455-472.

- Jaspars, J. M. F. (1978). The Nature And Measurement Of Attitudes. In Tajfel, H. i Fraser, C. (Eds.). Introducing Social Psychology (pp. 256-276). Harmondsworth: Penguin Book.

- Lambert, E. G., Hogan, N. L, Barton, S. i Stevenson, M. T. (2007). An Evaluation of CHANGE, a Pilot Prison Cognitive Treatment Program. Journal of Articles in Support of the Null Hypothesis, 5(1), $1-18$.

- Legrand, L. (2001). Moralna izobrazba danas: ima li to smisla? (Enseigner la morale aujourd'hui?). Prijevod Noemi Jugwirth. Zagreb: Educa.

- Lotkowski, V.A., Robbins, S. B. i Noeth, R. J. (2004). The Role of Academic and Non-Academic Factors in Improving College Retention (ACT Policy Report). Pristupljeno na internet stranici ACT: http://www.act.org/research/policymakers/pdf/college retention.pdf.

- Manoah, S. A., Indoshi, F. C. i Othuon, L. O. A. (2011). Influence of attitude on performance of students in mathematics curriculum. Educational Research, 2(3), 965-981.

- Mayer, R. E. i Wittrock, M. C. (2006). Problem Solving. In Alexander, P. A. i Winne, P. H. (Eds.). Handbook of educational psychology (2nd ed.), (pp. 287-304). Mahwah, NJ: Lawrence Erlbaum Associates.

- McCoach, D. B. i Siegle, D. (2003a). Factors That Differentiate 
Underachieving Gifted Students From High-Achieving Gifted Students. Gifted child quarterly, 47(2), 144-154.

- McCoach, D. B. i Siegle, D. (2003b). The school attitude assessment survey-revised: new instrument to identify academically able students who underachieve. Educational and Psychological Measurement, 63(3), 414-429.

- Myers, D. G. (2012). Exploring Social Psychology (6th ed.). New York: McGraw - Hill.

- Okuda, M., Balán, I. Petry, N., Oquendo, M. i Blanco, C. (2009). Cognitive-Behavioral Therapy for Pathological Gambling: Cultural Considerations, American Journal of Psychiatry, 166, 1325-1330.

- Overholser, J. C. (1993). Elements of the Socratic Method: I. Systematic Questioning. Psychotherapy, 30(1), 67-74.

- Pantalone, D. W., Iwamasa, G. Y. i Martell, C. R. (2010). Cognitive-Behavioral Therapy with Diverse Populations. In Dobson, K. S. (Ed.), Handbook of Cognitive - Behavioral Therapies (3rd ed.), (pp. 445-464). New York: The Guilford Press.

- Pennington, D. C. (2004). Osnove socijalne psihologije (Essential of social psychology). Preveo Boris Mlačić (treće izdanje). Jastrebarsko: Naklada Slap.

- Schwartz, S. H. (1992). Universals in the Content and Structure of Values. Theoretical Advances and Empirical Studies in 20 Countries. Advances in Experimental Psychology, 25, 1-65.

- Smith, R. E. i Swinyard, W. R. (1983). Attitude-Behavior Consistency: The Impact of Product Trial Versus Advertising. Journal of Marketing Research, XX, 257-267.

- Stern, M. (2012). Evaluating and Promoting Positive School Attitude in Adolescents. New York: Springer.

- Šiber, I. (1998). Osnovi političke psihologije. Zagreb: Politička kultura

- Throop, C.J.i Murphy, K. M.(2002). Bourdieu and phenomenology: A critical assessment. Anthropological Theory, 2(2), 185-207.

- Tett, L. (1999). Widening provision in higher education - some nontraditional participants' experiences. Research Papers in Education, 14(1), 107-119.

- Van Rossem, K. (2006). What is a socratic dialogue? Filosofie, 16(1), 48-51.

- Walpole, M. (2003). Socioeconomic Status and College: How SES 
Affects College Experiences and Outcomes. The Review of Higher Education, 27(1), 45-73.

- Whiteley, T. R. (2006). Using the Socratic Method and Bloom's Taxonomy of the Cognitive Domain to Enhance Online Discussion, Critical Thinking, and Student Learning. Developments in Business Simulation And Experiential Learning, 33, 65-70.

- World Health Organization (WHO) Regional Office for Europe (2011). Impact of economic crises on mental health. Pristupljeno na: http://www.euro.who.int/_data/assets/pdf_file/0008/134999/ e94837.pdf.

- Longmore, R. J. i Worrell, M. (2007). Do we need to challenge thoughts in cognitive behavior therapy? Clinical Psychology Review, 27, 173-187.

- Yi, Y. (1989). An investigation of the structure of expectancy-value attitude and its implications. International Journal of Research in Marketing, 6, 71-83. 
HRONIKA, KRITIKA, POLEMIKA 



\section{VAŽNOST OBRAZOVANJA ZASNOVANOG NA KOMPETENCIJAMA I ŽIVOTNIM VJEŠTINAMA ZA RAZVOJ DRUŠTVA}

\section{- Sažetak -}

Obrazovanje zasnovano na kompetencijama ima višestruk značaj. Sticanja takvih znanja i vještina posebno je važno u savremenom dobu kada se društveni razvoj, $i$ to u svim njegovim bitnim segmentima, sve više bazira na kompetentnim znanjima $i$ vještinama. Kroz njihovo razvijanje $i$ primjenjivanje pruža se mogućnost dosezanja ne samo društvenih nego $i$ osobnih potencijala koje, nerijetko, ne možemo ni da sagledamo upravo zbog nedostatka kompetentnih znanja i vještina. Nije slučajno unutar Evropske unije određeno čak osam ključnih kompetencija neophodnih kako za lični tako i za kvalitativni društveni razvoj, što je predmet opservacije i u ovom radu.

\section{Ključne riječi: obrazovanje, kompetencije, društveni razvoj.}

\section{Uvod}

Nesumnjiva je važnost obrazovanja u ljudskom društvu, kako za pojedinca tako i za društvo u cjelini. Obrazovanje zasnovano na kompetencijama omogućava dosezanje vlastitih potencijala, kao i potencijala društva u cjelini. Primjereno je društvu znanja i konceptu cjeloživotnog učenja koje je paradigma XXI vijeka, vijeka informatike, globalizacije, brzog razvoja nauke i tehnike, ali isto tako i vijeka nestajanja starih i nastajanja novih poslova $\mathrm{i}$ radnih mjesta, sve većih i bržih promjena kojima se trebamo prilagoditi.

1 Vesna Banović, magistar sociologije, završila master studij na Fakultetu političkih nauka u Sarajevu (Odsjek sociologija), odbranila master tezu 2013. godine, na temu „Uticaj obrazovanja zasnovanog na kompetencijama i životnim vještinama na razvoj društva". Radila je za više međunarodnih organizacija i agencija i projekata (EC, UNICEF, OSCE). 
Nefunkcionalna država Bosna i Hercegovina i njen aparat koji ne može da se nosi sa naraslim problemima još su više podstaknuti globalnom ekonomskom krizom i recesijom. Velika nezaposlenost, posebno mladih, koja prelazi $50 \%$ radno sposobnog stanovništva, ratom razorena zemlja sa unazađenom i devastiranom ekonomijom i privredom, promjena društvenog sistema, tegoban poslijeratni oporavak, pristupanje EU integracijama, kao i vrlo složena organizaciona struktura zemlje sa dva entiteta, Distriktom Brčko i deset kantona, koji otežavaju donošenje odluka i efikasno rukovođenje, otežavajući je kontekst u kome se obrazovanje u BiH nalazi. Također, ne bi se smjelo zaboraviti da je bosanskohercegovačko društvo multietničko, sa elementima povratka nekadašnjoj interkulturalnosti, niti da su globalizacija i cjeloživotno učenje okvir u kome se nalazimo. U ovako složenom okviru promatrati ulogu obrazovanja, i to onog zasnovanog na kompetencijama, pravi je izazov i višeslojan zadatak.

Šta je to što želimo, kao društvo i čemu težimo? Koje vrline njegujemo i kakve ljude pripremamo za život? Da li želimo da se prilagođavamo, održavamo status quo, ili želimo da prosperitetno kreiramo svoju stvarnost $\mathrm{i}$ budućnost? Mnogo je pitanja, a odgovori na njih zavise i od uređenja države i društveno-ekonomskog sistema kao dominantnog vrijednosnog orijentira. Reduciranje nejednakosti u drušvu, kreiranje šansi za prosperitetan razvoj, ili održavanje statusa quo u društvu, predstavljaju i obrazovni izazov. U tom smislu nam je potreban obrazovni sistem zasnovan na kompetencijama, znanjima i vještinama usklađenim sa zahtjevima vremena.

\section{Pojmovni kontekst}

Kad je riječ o kompetencijama i njihovom značaju u obrazovnoj djelatnosti, u pojmovnom kontekstu čini se važnim naglasiti sljedeće:

Ključne kompetencije su prenosivi multifunkcionalni sklop znanja, vještina i stavova koji su potrebni svim pojedincima za njihovu realizaciju i razvitak, uključivanje u društvo i zapošljavanje. Treba ih razviti do kraja obaveznog obrazovanja, jer predstavljaju temelj za dalje osposobljavanje kao dio cjeloživotnog učenja. Iz ovakve definicije vidljivo je da su ključne kompetencije prenosive i stoga primjenljive u mnogim situacijama i kontekstima. One su preduvjet za odgovarajuću ličnu uspješnost u životu, radu i daljem učenju. ${ }^{2}$

2 Agencija za predškolsko, osnovno i srednje obrazovanje Bosne i Hercegovine: Identifikacija ključnih kompetencija i životnih vještina, 2010., MDGF YERP (Program zapošljavanja i zadržavanja mladih), 2010. 
Evropski okvir ključnih kompetencija i cjeloživotnog učenja je identifikovao i definisao osam ključnih kompetencija neophodnih za lični razvoj, aktivno građanstvo, socijalnu inkluziju i zapošljivost u društvu znanja, a to su:

1. Komunikacija na maternjem jeziku. Uključuje znanje i upotrebu maternjeg jezika kao i sposobnost izražavanja i tumačenja misli, osjećaja i činjenica u usmenom i pisanom obliku u cijelom nizu društvenih i kulturnih okolnosti;

2. Komunikacija na stranimjezicima. Uključuje znanjei upotrebu stranog jezika kao i sposobnost razumijevanja, izražavanja i tumačenja misli, osjećaja i činjenica u usmenom i pisanom obliku u primjerenom nizu društvenih okolnosti na jezicima koji nisu maternji;

3. Matematičke kompetencije $i$ osnovne kompetencije $u$ nauci $i$ tehnologiji. Na osnovnom nivou uključuje sposobnost vršenja matematičkih operacija, a na naprednom sposobnost i spremnost korištenja matematičkih oblika mišljenja koji imaju univerzalnu primjenu;

4. Informatička kompetencija. Uključuje sigurno i kritičko korištenje informatičkih tehnologija na poslu, u slobodno vrijeme i u komunikaciji. Ova kompetencija je povezana sa logičkim i kritičkim razmišljanjem, s visoko razvijenim vještinama baratanja informacijama i razvijenim vještinama komuniciranja;

5. Učiti kako se uči. Predstavlja sklonost organiziranja sopstvenog učenja, učinkovitog upravljanja vremenom te rješavanja problema. Takođe obuhvata i primjenu novih znanja i vještina u različitim kontekstima;

6. Socijalne i građanske kompetencije. Obuhvataju skup kompetencija koje pojedincu omogućavaju aktivno sudjelovanje u građanskom životu društva;

7. Inicijativa i preduzetništvo. Ova kompetencija predstavlja sposobnost da se planiraju i izvode projekti, da se vlastite ideje pretvore u praksu, da se bude spreman na preuzimanje rizika koji nosi svaka samostalna preduzetnička aktivnost;

8. Kulturna svijest i izražavanje. Predstavlja prepoznavanje i poštovanje kreativnog izražavanja ideja i osjećaja preko čitavog niza medija: muzike, vizualne umjetnosti, plesa, literature te prepoznavanje i poštovanje estetike. 
Ovim kompetencijama pridružene su dvije za područje BiH s obzirom na njenu specifičnost i potrebe, a to su:

1. Kreativno-produktivne kompetencije,

2. Tjelesno- zdravstvene kompetencije. ${ }^{3}$

Od 10 predloženih, fokusiraćemo se na tri kompetencije izuzetno bitne za postkonfliktno bosanskohercegovačko društvo: socijalno-građanske, preduzetničke i učiti kako se uči. Pomenute tri kompetencije su odabrane zbog njihove aktuelnosti u bh. društvu.

Životne vještine su one koje pridonose ličnom rastu i razvoju, tj. ostvarenju punog potencijala svake osobe, kako bi ona bila spremna suočiti se sa svim izazovima koje nosi život. Pomoću životnih vještina pojedinac je u stanju da istražuje alternative, promišlja i pravi efikasne izbore pri rješavanju problema. Takođe je u stanju da ostvari kvalitetne interpersonalne odnose $i$ komunikaciju.

Svjetska zdravstvena organizacija (WHO) definira životne vještine kao sposobnost za prilagodljivo i pozitivno ponašanje, koje omogućava pojedincima da se efikasno suočavaju sa zahtjevima i izazovima svakodnevnog života.

Također, UNICEF, UNESCO, zajedno sa WHO, daju popis strategija i tehnika 10 životnih vještina, a to su:

- rješavanje problema,

- kritičko mišljenje,

- efektivne komunikacijske vještine,

- odlučivanje,

- kreativno mišljenje,

- vještine interpersonalnih odnosa,

- vještine izgradnje samosvjesnosti,

- empatija,

- upravljanje stresom i

- upravljanje emocijama. ${ }^{4}$

Nedostajuće vještine prepoznate kroz više recentnih istraživanja Svjetske banke su:

- komunikacijske vještine,

- sposobnost rješavanja problema,

- sposobnost nezavisnog rada,

3 Ibid.

4 Ibid. 
- kako iskoristiti znanje i socijalne vještine za funkcionisanje u XXI vijeku i za obavljanje posla.

Pored nabrojanih, u Bosni i Hercegovini nedostaju sljedeće vještine i kompetencije:

- znanje stranog jezika,

- informatičke kompetencije,

- preduzetničke kompetencije,

- vještine javnog nastupa, stvaranja i prezentacije vlastitih nezavisnih stavova.

Zanimljiv je i indikativan kontekst u kome je nastao koncept cjeloživotnog učenja. Veoma je značajan uticaj Evropske unije na razvoj cjeloživotnog učenja, a Evropska unija je u sebi sublimirala 2 pristupa:

- OECD-ov neoliberalni,

- UNESCO-ov humanistčki.

Humanistički pristup podrazumijeva obrazovanje za samoostvarenje i ima široke socijalne i kulturne ciljeve, te predstavlja socijaldemokratski pristup. S druge strane, neoliberalni pristup podrazumijeva instrumentalizaciju obrazovanja putem njegove uglavnom ekonomske uloge. Evropski pristup obrazovanju zasnovan na ekonomiji znanja i postizanju velike konkurentnosti (evropska ekonomija da postane najkonkurentnija na svijetu, Lisabonski sporazum iz 2000.), uvažava oba ova principa i u sebi inkorporira ekonomske i demokratske ciljeve. Međutim, njihova dominantnost je različita kroz etape, počevši od prvobitnog nastanka koncepta cjeloživotnog učenja sredinom 60-ih godina XX vijeka pa do današnjih dana. Može se reći da je jačanje kriza podupiralo ekonomski princip neoliberalnog kapitalizma, dok je u stabilnija vremena dolazio do izražaja onaj socijaldemokratski, zasnovan na univerzalnom znanju.

U svakom slučaju, cjeloživotno učenje kao vrlo rastegljiv i prilagodljiv pojam koristi se u različitim zemljama za različite svrhe, gdje dominiraju ekonomski ciljevi i konkurentnost, a razlozi ličnog razvoja i aktivnog građanstva, kao humanističko-građanski ciljevi, bivaju potisnuti. Pored aktivnog građanstva, tu je i socijalna kohezija te razvoj multietničkog društva kao vrlo koristan faktor u višenacionalnim društvima pri rješavanju problema sa kojima se ona susreću, te posebno u rješavanju konflikata u postkonfliktnim zajednicama. 


\section{Socijalno-građanske kompetencije}

Socijalno-građanske kompetencije uključuju lične, interpersonalne i interkulturalne kompetencije i pokrivaju čitav niz ponašanja koja omogućavaju osobi da na efikasan i konstruktivan način učestvuje u socijalnom okruženju, sa posebnim naglaskom na multikulturna i multietnička društva, te da rješava konflikte na miran i konstruktivan način. Građanska komponenta znanja još uključuju i poznavanje koncepata demokratije, pravde, jednakosti, građanskih prava i bazičnih dokumenata koji garantuju ljudska prava. Ovo uključuje i poznavanje istorijskih činjenica vezanih za demokratizaciju i ustroj Evropske unije i vlastite države. Razvoj ove kompetencije ima u osnovi izgradnju vrijedonosnog sistema koji uključuje brigu za drugog, razumijevanje drugog i vještine da se sarađuje i konstruktivno djeluje u društvu. ${ }^{5}$ Ova kompetencija se uglavnom stiče na predmetima demokratija, istorija i geografija. Na razvoju vještina i stavova se radi na većem broju predmeta i to uglavnom društvenohumanističke grupe i maternjeg jezika.

Razvoj i napredak svakog pojedinca značajno zavisi od mogućnosti njegova uključivanja u aktivnosti zajednice u kojoj se nalazi. Polaskom u školu, te prvim socijalnim uključivanjem, učenici usvajaju oblike ponašanja prihvatljive za grupu i stiču osnovna znanja, vještine i stavove interpersonalne komunikacije. Razvojem i sazrijevanjem pojedinca proširuje se i njegova društvena uključenost, koja nalaže i potrebu za usvajanjem osnovih znanja, vještina i stavova vezanih za građanske kompetencije.

Interpersonalna kompetencija se odnosi na skup usvojenih oblika ponašanja koji su potrebni pojedincu za lično uključivanje u aktivnosti zajednice i interakciju sa drugim članovima. Interpersonalna kompetencija je preduslov za odgovarajuću komunikaciju između jednog i drugog člana zajednice. Građanske kompetencije predstavljaju znanja, vještine i stavove koji su neophodni svakom pojedincu radi uspješnijeg uključivanja u građanski život društva u kojem se nalazi.

Usko vezano sa građanskim kompetencijama je i obrazovanje za demokratsko društvo i obrazovanje o ljudskim pravima. Vijeće Evrope je donijelo Povelju Vijeća Evrope o obrazovanju za demokratsko društvo i obrazovanju o ljudskim pravima koja je usvojena u obliku preporuke na Komitetu Ministara 2010. godine. „Obrazovanje za demokratsko društvo” označava obrazovanje, obuku, jačanje svijesti, informacije, prakse i aktivnosti koje imaju za cilj da pojedinci, putem sticanja znanja, vještina i shvatanja

5 Agencija za predškolsko, osnovno i srednje obrazovanje Bosne i Hercegovine: Analiza nastavne prakse, MDGF YERP (Program zapošljavanja i zadržavanja mladih), 2010. 
i razvoja stavova i ponašanja, budu osnaženi u upražnjavanju i branjenju svojih demokratskih prava i odgovornosti u društvu, da vrednuju raznolikost i igraju aktivnu ulogu u demokratskom životu, sa ciljem promicanja i zaštite demokratije i vladavine zakona. „Obrazovanje o ljudskim pravima” označava obrazovanje, obuku, jačanje svijesti, informacije, prakse i aktivnosti čiji je cilj da pojedinci, putem sticanja znanja, vještina i shvatanja, razvoja stavova i ponašanja, budu osnaženi u davanju doprinosa izgradnji i branjenju univerzalne kulture ljudskih prava u društvu, sa ciljem promicanja i zaštite ljudskih prava i osnovnih sloboda. ${ }^{6}$

Odgoj i obrazovanje za ljudska prava i demokratsko građanstvo sadržava u sebi mnoge oblasti, kao što su:

- Razvoj socijalnih vještina, a posebno komunikacije i nenasilnog rješavanja sukoba;

- Tolerancija i uvažavanje različitosti;

- Poznavanje ljudskih prava i njihove adekvatne zaštite, kao i odgovornosti svake osobe za njihovo poštovanje;

- Ljudska prava i rodna ravnopravnost;

- Odgovorno ponašanje;

- Razvoj kritičkog mišljenja;

- Razumijevanje društvenih procesa i političkih sistema;

- Aktivno građanstvo i demokratija;

- Razumijevanje pojma multietničnosti, multikulturalizma i interkulturalizma;

- Poznavanje mehanizama djelovanja organizacija civilnog društva te upoznavanje sa mogućnostima udruživanja;

- Volonterizam;

- Aktivizam mladih;

- Razvoj preduzetničkog duha;

- Drugo.

Kao što možemo da vidimo, građanske kompetencije se umnogom dotiču obrazovanja za ljudska prava i demokratsko građanstvo. Nemanje građanskih kompetencija onemogućava pojedinca da bude aktivan građanin i da utiče na razvoj društva. Kod obrazovanja za ljudska prava izuzetno važnu ulogu nosi poznavanje Univerzalne deklaracije o ljudskim pravima, usvojene posebnom rezolucijom 1948. na zasjedanju Generalne skupštine Ujedinjenih nacija kao odgovor na enormno stradanje i patnju ljudi u II svjetskom ratu. Nepoznavanje ljudskih prava kao takvih, a Deklaracija ih detaljno navodi, te

6 Povelja Vijeća Evrope o ljudskim pravima. 
njihove zaštite, vodi ka neznanju i nesenzibiliziranosti kod kršenja tih istih prava. Ovaj proces je obostran: ne znaju ih nekada ni oni koji ih krše, a ni oni kojima su prekršena. U postratnim tranzicijskim multietničkim društvima ovo je posebno važno.

Netolerancija i neuvažavanje različitosti dovodi između ostalog i u konačnici i do ratnih sukoba. U slučaju Bosne i Hercegovine ovo je posebno značajno, ratom razorenom društvu potrebno je ponovno razvijanje duha tolerancije i uvažavanja različitosti jer samo tako ono može opstati. Za Bosnu i Hercegovinu su izuzetno bitni multietničnost i interkulturalizam. Za razliku od interkulturalizma, multikulturalizam pdrazumijeva življenje više kultura jednih pored drugih. Oni traže toleranciju i demokratičnost, a posebno interkulturalizam koji podrazumijeva zajedničku kulturu koja prihvata različitosti koje u nju ulaze i stapaju se. Sve ovo pod pretpostavkom da se želi razvoj tog i takvog društva. U slučaju Bosne i Hercegovine na razvoj društva djeluje više, nekad vrlo suprotstavljenih sila i politika. Nerazvijanje građanskih kompetencija i nemanje obrazovanja za demokratsko građanstvo vice versa sprečava razvoj društva. Ono podrazumijeva pasivne građane kojima je puno lakše manipulisati sa ciljem ostvarivanja nečijih prvo ličnih, a zatim i kroz partije i institucije sistema etabliranih interesnih grupa.

Demokratizacija društva je pretpostavka za demokratizaciju obrazovanja, a s druge strane, obrazovanje je pretpostavka razvoja društva. S tim u vezi javlja se potreba za novim područjima obrazovanja, poput obrazovanja za demokratsko građanstvo, čiji je cilj da doprinese razvoju kritičkog mišljenja i građanske odgovornosti, te da podstakne na građansku participaciju i aktivizam. Građansko obrazovanje utiče i na razvoj socijalnog kapitala u smislu stvaranja konstruktivnih veza na privatnom i javnom nivou koje će uticati na samoostvarenje pojedinca, a preko pojedinaca i na razvoj društva. Ove veze se na institucionalnom nivou ostvaruju preko udruženja, političkih partija, sindikata. Oni stvaraju mreže među ljudima te društveno povjerenje, koji olakšavaju saradnju na svakom planu i dovode do „win-win situacija” i uzajamne koristi povezanih.

Obrazovanje je političko i demokratsko pitanje. Razvojem građanskih kompetencija razvija se socijalni kapital i aktivni građani, što je preduslov demokratizacije i političke participacije aktivnih i odgovornih građana, a ta participacija odgovornih i aktivnih građana je uslov razvoja uravnoteženog društva. Demokratizacija društva podrazumijeva demokratizaciju njegovih članova te $\mathrm{u}$ tom smislu građanske kompetencije doprinose poštovanju drugačijeg mišljenja, utiču na vještinu debate i debatovanja, utiču na 
uočavanje i rješavanje društvenih problema te na moralnu odgovornost i političku kulturu. Sve nabrojano je uslov političkog, ekonomskog i, u konačnici, društvenog razvoja.

\section{Preduzetničke kompetencije}

Preduzetničke kompetencije podrazumijevaju sposobnost planiranja i izvođenja projekata, provođenje ideja u praksu te spremnost na preuzimanje rizika koji nosi svaka samostalna preduzetnička aktivnost. Kod ovih kompetencija je izuzetno važan element stava jer smo svjedoci da velik broj mladih, ali i onih starijih, posjeduju stručne kompetencije i sjajne ideje, ali iz straha od preuzimanja rizika i nespremnosti na samostalan rad ne usuđuju se pokrenuti vlastiti projekat ili preduzeće. Pozitivan stav upravo i uključuje proaktivnost, nezavisnost, motivaciju i spremnost na preuzimanje rizika bez straha od poraza. Razvoj ovih kompetencija se tradicionalno veže za stručne predmete, mada se očekuje da se samoinicijativa razvija unutar svih predmeta u redovnom školovanju.

Stoga se valja zapitati kako se razvijaju komponente samoinicijative i preduzetničkih kompetencija u pojedinim obrazovnim programima i u kojim predmetima. Analiza razlika u razvoju samoinicijative i poduzetničkih kompetencija između obrazovnih nivoa pokazuje vrlo interesantan rezultat. Osnovne škole nešto više rade na razvoju ove kompetencije nego gimnazije. Konkretno, u osnovnim školama se više radi na razvoju vještina timskog rada, razvijanju spremnosti na preuzimanje rizika i inicijative nego u gimnazijama.

U osnovnim školama, predmet koji dominantno razvija samoinicijativnost je demokratija; u njemu učenici rješavaju probleme u timovima i bivaju poticani na javno izražavanje mišljenja i debate sa svojim kolegama/kolegicama. U osnovnim školama su značajni predmeti za razvoj samoinicijativnosti i prirodoslovni predmeti, u kojima se više radi na razvoju vještina i stava, a ne toliko na usvajanju znanja (očekivano). U gimnazijama, demokratija je predmet na kojem nastavnici najviše insistiraju na usvajanju znanja, dok nastavnici filozofije najviše rade na razvoju stava.

U stručnim školama, demokratija više nije toliko značajna osim za usvajanje znanja, dok se vještine i stavovi razvijaju u prirodoslovnoj i društvenohumanističkoj grupi predmeta. Treba istaknuti i rezultate nastavnika u maternjem i stranom jeziku, koji u svim obrazovnim programima rade na razvoju vještina i stavova. Ohrabrujuća je činjenica da se nastavnici skoro svih predmeta trude da rade na vještinama i stavovima, što je vidljivo na prosječnim vrijednostima po elementima u svim obrazovnim programima. 
Možemo zaključiti da nastavnici većine predmeta različitim oblicima rada (timski rad, projekti) potiču razvoj vještina i stavova vezanih za samoinicijativu i poduzetničke kompetencije, a predmet na kojem učenici svih obrazovnih programa stiču najviše znanja je demokratija. ${ }^{7}$

Što se tiče razvijanja kompetencija kroz neformalno obrazovanje, situacija je drugačija i vrlo šarolika te bazirana uglavnom na projektima stranih agencija ili nevladinih organizacija (NVO). Više se projekata na području BiH bavilo ili se bavi razvijanjem poduzetničkih kompetencija kod srednjoškolske populacije učenika i oni su vrlo često takmičarskog karaktera. Školski timovi sastavljeni od najčešće desetak učenika dobijaju ograničena, ali poticajna donatorska sredstva ili se za njih izbore, u zavisnosti od metodologije projektnog ciklusa. Timovi prate cijeli projektni ciklus ovih mini projekata, te tako na djelu razvijaju i uključuju više usvojenih znanja i vještina te razvijaju nove: matematičke kompetencije za izradu i praćenje provedbe budžeta, jezičko-komunikacijske kompetencije na maternjem i stranom jeziku, javni nastup i prezentaciju, komunikaciju sa različitim zainteresovanim grupama, preduzetničke kompetencije itd. Mladi ljudi na ovaj način bivaju u situaciji da razvijaju i svoje građanske kompetencije tako da prvo rade snimanje situacije u svojoj okolini i daju presjek najurgentnijih potreba, koje onda pretoče u projektni prijedlog. Zatim skupljaju sredstva, provode projekat i javno predstavljaju njegove rezultate. Dakle višestruka korist je prepoznata kroz ove neformalne metode uvođenja poduzetničkih kompetencija u srednje škole.

Postoje i projekti uvođenja preduzetničkih kompetencija kroz neformalno obrazovanje za učenike osnovnih škola. Finansiranje ovih projekata za osnovnoškolce je rjeđe i sa manje sredstava, ali je pokazalo značajne rezultete u razvoju preduzetničkih vještina kod ove populacije. Radi se o učenicima završna tri razreda osnovnih škola. Njihovi projektni rezultati su veoma inspirativni i indikativni pokazatelji uspješnosti ranog razvoja kopetencija vezanih za preduzetništvo. Ispitivanje njihovih nastavnika - vođa timova pokazalo je veliku podršku ovakvom radu; nastavnici su kao preporuke istakli potrebu kontinuiranog ulaganja u ovakav vid aktivnosti te njihovo integrisanje u školske kurikulume. Uvođenje preduzetničkog učenja kroz neformalno obrazovanje prepoznat je i preporučen način integracije i u praksi provjeren kroz više projekata.

Evropskaunijai VijećeEvropeusvojoj recentnoj studiji,Uticaj neformalnog

7 Agencija za predškolsko, osnovno i srednje obrazovanje Bosne i Hercegovine: Identifikacija ključnih kompetencija i životnih vještina, 2010., MDGF YERP (Program zapošljavanja i zadržavanja mladih), 2010. 
obrazovanja u omladinskim organizacijama na zapošljivost mladih ljudi" navodi prednosti neformalnog obrazovanja mladih. Komunikacija, timski rad, donošenje odluka, organizacione vještine i samouvjerenost samo su neke od preporučenih vještina koje se razvijaju kroz neformalno obrazovanje. One su najtraženije kod poslodavaca pa tako ova vrsta obrazovanja razvija kompetencije potrebne za lakšu zapošljivost i zapošljivost generalno. Tu su i liderstvo i inerkulturalnost. Participacija u omladinskim projektima razvija socijalni kapital mladih i povezuje ih sa tržištem rada premošćujući nedostatak formalnog iskustva. To dalje znači preporuku vlastima za ulaganje više političke volje i finansija u neformalno obrazovanje mladih kako bi što više njih imalo pristup i povećanu mogućnost zapošljavanja.

„Strategija učenja o poduzetništvu u obrazovnim sistemima u $\mathrm{BiH}$ za period 2012-2015" je donesena 2011.godine. Ona predviđa uvođenje učenja o poduzetništvu u postojeće predmete u okviru postojećeg nastavnog plana i programa. Ova strategija slijedi EU definiciju preduzetništva, koja glasi: „Preduzetništvo se odnosi na mogućnost pojedinca da ideju pretvori u djelo. Ono uključuje kreativnost, inovativnost i sposobnost preuzimanja rizika, kao i mogućnost da pojedinac planira i provede projekte kako bi postigao određene ciljeve. Ovaj koncept pomaže svima u svakodnevnom životu, kod kuće, kao i među društvom; čini zaposlenike svjesnijim konteksta svoga posla i sposobnijim da iskoriste prilike, te predstavlja podršku preduzetnicima u pokretanju društvenih ili komercijalnih aktivnosti,,.8

Posebna tema su žene i preduzetništvo. Poslijeratni period i promjena društvenog uređenja u Bosni i Hercegovini odrazili su se i na žene i na muškarce te, uz istodobni uticaj globalizacije i promjene u sigurnosti radnih mjesta te nezaposlenosti, uticali su na žensko samozapošljavanje i na žensko preduzetništvo. Sa dolaskom rata dolazi do promjena na polju zapošljavanja kako muškaraca tako i žena. Žene počinju da posvećuju svoje vrijeme, karijeru i energiju prihvatajući bilo kakve poslove i istovremeno preuzimajući ulogu hraniteljice porodice. Neke su se u tome odlično snašle, razvile svoje potencijale, pronašle načine za zaradu, povezale se sa tržištem. Neke od njih su posao našle u mnogobrojnim novoosnovanim NVO-ima. Neki od NVO-a su počeli implementirati različite razvojne projekte te su angažovali žene za izradu ručnih radova ili za rad u poljoprivredi, u plastenicima, sa stokom na mini farmama, kao kooperante za mljekare i slično, u zavisnosti od projektnog zadatka i cilja. A neke žene su same sebe i one oko sebe organizovale pa

8 Ministarstvo civilnih poslova $\mathrm{BiH}$ : Strategija učenja o poduzetništvu u obrazovnim sistemima u BiH za period 2012- 2015. 
su koristile poplavu stranih i domaćih organizacija kao način ostvarivanja prihoda, sticanja novih znanja i vještina, povezivanje sa bližom i daljom okolinom.

Nakon rata kreće i razvoj malih i srednjih preduzeća. Pojedine strane donatorske organizacije, vladine i nevladine, programi, projekti i institucije, nudili su start up kredite upravo za žensko preduzetništvo kao i posebne obuke za osnaživanje žena i ženskog preduzetništva. Razvoj malih biznisa zavisio je i zavisi još uvijek od mnogo faktora, ali ono što je nesporno jesu poticaji i mogućnosti, koji su se ukazali ženama. Oni su im nudili način preživljavanja i izlaska iz siromaštva. Za one koje su se „,snašle, , i nešto više od toga. Pitanje je da li bi se neke od ovih pomenutih žena preduzetnica ikada prije rata, u drugačijim životnim i društvenim uslovima, bavile ovakvim poslovima. Specifična potkategorija su žene u 40-im koje su se počele baviti preduzetničkim aktivnostima nakon što su im djeca odrasla, a one ostale sa viškom vremena i energije, a manjkom finansijskih sredstava. Preduzetničke kompetencije ove kategorije je potrebno jačati serijom treninga; one će uticati na samopoštovanje, organizovanost, timski rad, razmjenu iskustava i znanja. Potrebno je učenje o preduzetništvu učiniti dostupnim što većem broju žena te razvijati preduzetničke kompetencije. Potrebno je, a bazirano na preduzetničkom znanju, promovisati i finansirati žensko preduzetništvo te organizovati obuke žena za preduzetništvo.

\section{Učiti kako se uči}

Učiti kako se uči predstavlja sklonost i sposobnost organizovanja i uređivanja vlastitog učenja bilo pojedinačno ili u grupi. Sastoji se od sposobnosti da učinkovito upravljamo svojim vremenom, rješavamo probleme, stičemo, procesuiramo, ocjenjujemo i asimiliramo znanje te da novo znanje i vještine primjenjujemo u raznim kontekstima - kod kuće, na poslu i u obrazovanju. Generalno govoreći, učiti kako se uči snažno doprinosi mogućnosti da upravljamo vlastitom karijerom. ${ }^{9}$

Učiti kako se uči je vrlo složena (kroz)kurikularna kompetencija, ali i vrlo važna za koncept cjeloživotnog učenja. Ona uključuje upravljanje procesom učenja, upravljanje vremenom, istrajnost, koncentraciju, sposobnost rješavanja problema, sposobnost samoprocjene, primjenu znanja i vještina, pravljenje obrazovnih izbora, upravljanje karijerom. Dakle, vrlo je važna u situaciji stvaranja novih poslova, nestanka starih te primjene naučenog.

9 Institut za društvena istraživanja Zagreb i ETF: Ključne kompetencije „Učiti kako učiti” i „Poduzetništvo” u osnovnom školstvu Republike Hrvatske, Istraživački izvještaj. 
Princip cjeloživotnog učenja traži prilagodljivost i primjenu novih znanja te ličnog i profesionalnog usavršavanja kako bi se postigla fleksibilnost u pristupu tržištu rada. Iz svih tih razloga kompetencija učiti kako se uči postaje ključnom kompetencijom XXI vijeka. Pojedinci koji ne znaju šta i kako učiti te kako se karijerno usavršavati mogu koristiti usluge centara za karijerno usmjeravanje i profesionalnu orijentaciju. Ova kompetencija je sadržajno najviše zastupljena u predmetima maternji jezik i istorija, a najmanje u nastavi biologije, hemije i fizike. U kontekstu akademskih dostignuća, kompetencija učiti kako se uči postaje vrijednost sama po sebi, koja omogućava samostalan rast i razvoj pojedinaca kroz njihov život i rad.

Treba napomenuti da je ova kompetencija posebno vezana za period nakon zadnjeg rata. Prije prihvatanja koncepta cjeloživotnog učenja i promjena na tržištu rada, učenje je uglavnom bilo kanalisano školskim sistemom. Ovakav pristup bio je u skladu sa mentalnim sklopom ljudi koji su bili naviknuti da neko drugi za njih trasira put: škola, fakultet, stalno zaposlenje. Nije se poticalo usavršavanje niti različiti karijerni izbori i promjene karijera. Promjene su donijele i nove paradigme: učimo cijeli život i mijenjamo više poslova u toku našeg radnog vijeka. Šta konkretno preduzeti da bi se mladi ljudi pripremili za učenje za cijeli život? Potrebno je organizovati karijerna savjetovališta pri osnovnim i srednjim školama koja će davati ne samo smjernice u vezi izbora buduće karijere nego i savjete u vezi učenja. Također je potrebno razvijati kompetenciju učiti kako se uči kroz različite predmete s obzirom na specifičnosti svakog predmeta i svakog učenika te na taj način kod učenika poticati ljubav prema učenju i znanju.

\section{Zaključna razmatranja}

Bosna i Hercegovina je od srednje razvijene evropske države prije rata došla u red nerazvijenih zemalja sa visokom stopom nezaposlenosti, prema evropskim mjerilima. Obrazovanje je postalo važan element u smanjenju siromaštva. Obrazovanje i edukacija povećavaju socijalni kapital i društvene veze na način da povećavaju ljudsku sposobnost funkcionisanja u društvu i kao članova društva, a to opet povećava ekonomski rast i razvoj. Socijalni kapital, s druge strane, povratno poboljšava obrazovne ishode, povećava toleranciju te smanjuje stopu kriminala. Dakle, obrazovanje je ključno za razvoj jer ne samo da povećava potencijale pojedinaca nego i društva u cjelini - socijalni kapital.

Potrebno je razvijati kompetencije i vještine sa posebnim osvrtom na one nedostajuće u bosanskohercegovačkom društvu kako bi se društvo 
brže razvijalo. Kritičko mišljenje, sposobnost iznošenja sopstvenih stavova, interpersonalne i komunikacijske vještine te upravljanje stresom samo su neke od vještina kojima je potrebno ovladati sada za sadašnjost i budućnost. Osim formalnog obrazovanja kao mjesta gdje bi se vještine i kompetencije trebale razvijati, vrlo je pogodno i obrazovanje odraslih. Također, treba poticati karijerno savjetovanje kako bi se osobe od mladih dana usmjeravale i razvijale u onom pravcu koji omogućava ostvarenje njihovih potencijala.

\section{IMPORTANCE OF COMPETENCE - BASED AND LIFE SKILLS - BASED EDUCATION FOR THE DEVELOPMENT OF SOCIETY}

\section{- Abstract -}

Competence-based education is multiply important, especially in modern times when the development of society, in all its substantial segments, is more and more based on acquisition of knowledge and skills. Development and usage of competences provide opportunity to scoop not only societal but also personal potentials, which we are often not able to comprehend due to lack of crucial knowledge and skills. It was no coincidence that within EU eight key competences were identified as necessary for both personal and social development, which is the object of observation in this work.

Key words: education, competences, social development.

\section{Literatura}

- Agencija za predškolsko, osnovno i srednje obrazovanje Bosne i Hercegovine: Identifikacija ključnih kompetencija i životnih vještina, 2010., MDGF YERP (Program zapošljavanja i zadržavanja mladih).

- Institut za društvena istraživanja Zagreb i ETF: Ključne kompetencije „Učiti kako učiti” i „Poduzetništvo” u osnovnom školstvu Republike Hrvatske, Istraživački izvještaj.

- Ministarstvo civilnih poslova BiH: Strategija učenja o poduzetništvu u obrazovnim sistemima u BiH za period 2012- 2015.

- Povelja Vijeća Evrope o ljudskim pravima. 
IZ PRAKSE OBRAZOVANJA ODRASLIH 

Milica Jaramaz ${ }^{l}$

UDK : 374.7 (497.16)

\title{
BARIJERE PARTICIPACIJE U OBRAZOVANJU ODRASLIH U CRNOJ GORI ${ }^{2}$
}

\begin{abstract}
- Sažetak -
U savremenom svijetu učenje i obrazovanje su način čovjekovog opstanka $i$ društvenog $i$ individualnog razvoja. Svjedoci smo da svakoga dana sve više narastaju obrazovne potrebe pojedinaca, tj. zaposlenje, napredovanje u profesiji, promjena ili zadržavanje radnog mjesta iziskuju uključivanje $u$ proces učenja $i$ obrazovanja. Poznato je da proces participacije odraslih u programima obrazovanja prate brojne barijere, a ishod toga je izrazito niska stopa participacije u Crnoj Gori, kao i u zemljama u regionu. Prema tome, ovaj rad je usmjeren na sagledavanje ključnih barijera u obrazovanju odraslih, zapravo cilj istraživanja se odnosio na utvrđivanje hijerarhije barijera $i$ utvrđivanje povezanosti između seta socijalno-demografskih obilježja i barijera obrazovanja kao i nivoa obrazovnog osujećenja.
\end{abstract}

Ključne riječi: obrazovanje odraslih, barijere obrazovanja, participacija.

\section{Teorijski okvir}

Participacija odraslih u učenju i obrazovanju je izuzetno kompleksan socijalno-psihološki fenomen, koji zaokuplja pažnju savremene naučne i stručne javnosti. Kada se raspravljava o obrazovanju i učenju odraslih, onda je skoro nezaobilazna analiza participacije odraslih u programima obrazovanja, jer je upravo ovo tema o kojoj se sve više govori, diskutuje, istražuje i koja se analizira. Naime, za područje obrazovanja odraslih neizmjerno je važno baviti se participacijom, tj. motivima i barijerama obrazovanja.

1 Mr. Milica Jaramaz, magistar pedagogije, saradnik u nastavi na Filozofskom fakultetu u Nikšiću, Univerzitet Crne Gore, Studijski program za pedagogiju.

2 Izvod iz magistarskog rada. 
Budući da nije jednostavno odgovoriti na pitanje zašto se odrasli uključuju u obrazovne aktivnosti, nije lako doći ni do odgovora zašto se odrasli ne uključuju u obrazovne aktivnosti. Stoga je uočavanje, sagledavanje i analiza barijera participacije jako važna kako bi se mogli pronaći putevi za njihovo prevazilaženje. Spoznaja ključnih barijera i njihovo razumijevanje i savladavanje obezbijediće nesmetano zadovoljavanje obrazovnih potreba pojedinaca. Upravo iz ovih razloga, kako pokazuju komparativna istraživanja, u andragogiji su često proučavane barijere participacije. Pored toga što se fenomen participacije odraslih u programima obrazovanja često istražuje mišljenja smo da ne gubi na aktuelnosti, jer je participacija uvijek uslovljena socijalnim kontekstom, tj. sredinom u kojoj se ostvaruje. Samim tim primjećujemo veliku raznorodnost kada su u pitanju barijere participacije, jer svaka sredina ima svoje specifičnosti i od brojnih faktora zavisi da li je određeni socijalni kontekst stimulišući ili destimulišući kada je u pitanju uključivanje odraslih u obrazovne aktivnosti.

Različita istraživanja ometajućih faktora procesa participacije, odnosno osujećenja tog procesa, utvrdila su postojanje brojnih barijera u obrazovanju odraslih. Jedno od najznačajnijih istraživanja je autorke Cross, koja je barijere participacije odraslih $\mathrm{u}$ obrazovanju klasifikovala $\mathrm{u}$ tri grupe: situacione, institucionalne i dispozicione (Kulić, Despotović, 2005: 164165). Ova klasifikacija je jedna od najranijih i poslužila je kao osnova za dalja istraživanja ovog problema. Svakako, bilo je značajno osvrnuti se na rezultate brojnih studija, a među njima izdvajamo rezultate istraživanja koje je poduzeto u Finskoj. ${ }^{3}$ Barijere participacije u obukama koje plaćaju poslodavci su: nedostatak vremena zbog previše obaveza na poslu; poslodavac ne nudi obuku; nedostatak odgovarajuće obuke; teškoće prilikom uključivanja u obuku; poslodavac ne vrednuje obuku; nedostatak informacija o mogućnostima; nedostatak beneficija od same obuke; nizak nivo kvaliteta obuke; nezainteresovanost; strah od neuspjeha; finansijske poteškoće; ostale prepreke. Osim ovih, istim istraživanjem ispitane su i barijere participacije odraslih u obrazovanju tokom slobodnog vremena i o trošku participanta. Na vrhu hijerarhije barijera participacije obrazovanja odraslih tokom slobodnog vremena i o trošku participanta su finansijski razlozi. Zatim, lokacija obuke, umor, nezainteresovanost, neprikladno radno vrijeme, nedostatak odgovarajućih obrazovnih programa, nedostatak benefita od obuke, nedovoljno osnovno obrazovanje, nedostatak informacija o mogućnostima, godine starosti i zdravstveno stanje, zadovoljenje drugih potreba u slobodnom

3 www.stat.fi/til/aku/1995. Dostupno: [19. 5. 2012.]. 
vremenu, problemi u odgajanju djeteta, slab kvalitet obuke, kućni i porodični razlozi, strah od neuspjeha i ostale prepreke.

Koliko je značajan nedostatak novca kao faktor osujećenja participacije u obrazovanju upravo nam pokazuju prethodno pomenuti rezultati, jer u hijerarhiji barijera obrazovanja koje plaća poslodavac zauzima posljednje mjesto, dok u hijerarhiji barijera gdje pojedinac sam snosi troškove obrazovanja zauzima prvo mjesto.

Carp, Peterson i Roelfs su analizirali aktivnosti učenja odraslih koji su već uključeni u učenje. Oni su prema važnosti istakli sljedeće barijere: troškovi, nedovoljno vremena, nedovoljno želje da se škola pohađa sve vrijeme, porodične odgovornosti, odgovornosti na poslu i količina vremena koja je potrebna da bi se završio program (Kulić, 1997: 112). Dakle, rezultati i ovog istraživanja upravo pokazuju da u hijerarhiji barijera primat zauzimaju nedostatak novca i nedostatak vremena. To nam govori da su čovjekovi egzistencijalni problemi ključni razlozi njegove neparticipacije u obrazovnim aktivnostima.

Shipp i McKenzie koristeći faktorsku anlizu otkrili su sljedeće faktore neparticipacije: odupiranje promjeni i obrazovanju, otuđenje, marginalizovanost, nedruželjubivost, nerelevantnost programa. ${ }^{4}$ Uočavamo da je ova klasifikacija barijera drugačija u odnosu na prethodne. Zapravo, ovdje su više opisane barijere, koje su u vezi sa ličnošću participanata, i koje zavise od njegovih stavova, percepcije i odnosa prema obrazovanju i okruženju. Osim toga, rezultati istraživanja u velikoj mjeri zavise od socijalnog konteksta kome ispitanici pripadaju. Budući da čovjekovo okruženje, sredina u kojoj živi determiniše participaciju u obrazovanju, na isti način determiniše i neparticipaciju.

I naši autori su se bavili problemom barijera participacije odraslih u obrazovanju i učenju. Stoga smatramo da je važno pomenuti i rezultate istraživanja prof. Savićevića. Rezultati pokazuju da se na vrhu rang-liste barijera kod ispitivanih muškaraca i žena nalaze nedostatak vremena i nedostatak novca. Treće mjesto zauzima nemanje mogućnosti da se ispitanici obrazuju u sredini u kojoj žive. Ostale barijere se odnose na percepciju ličnosti i mogućnosti ispunjavanja obrazovnih zadataka: nedostatak energije, obrazovanje ne pričinjava zadovoljstvo, slabi rezultati postignuti u prethodnom obrazovanju, stavovi pojedinca u vezi sa godinama koje smatraju pogodnim za učenje...(Savićević, 1989: 211-212).

4 Vidi: Malhotra, N., Sizoo, S., Chorvat, V. (1999): Barriers to adult participation in undergraduate education, „Adult Higer Education Alliance,,. Dostupno na: www.ahea.org/files/pro1999malhotra. pdf [20. 5. 2012.]. 
Osvrćući se na rezultate prethodnih istraživanja uviđamo da su barijere participacije odraslih u obrazovnim aktivnostima zaista raznorodne. Ono što se izdvaja $u$ većini istraživanja je činjenica da su nedostatak novca i nedostatak vremena ključni faktori osujećenja čovjekove participacije u učenju i obrazovanju. Pored toga što situacione barijere zauzimaju primat, nijedna zajednica ne bi trebalo da zanemaruje institucionalne i dispozicione barijere. Smatramo da svako društvo, kompanije, i pojedinci treba najprije da otkriju i identifikuju barijere, a zatim da pristupe sistematskom otklanjanju istih. Kako smo i ranije istakli, participacija odraslih u obrazovanju zavisi od samog pojedinca, zatim od materijalno-tehničkih uslova, odnosno postojanja objektivnih mogućnosti i od socijalnog konteksta. Upravo barijere participacije treba analizirati na navedenim nivoima $i$ raditi na njihovom savladavanju. Ovo dobija na važnosti ako se ima u vidu činjenica da su učenje i obrazovanje ključ razvoja svakog pojedinca i društva u cjelini.

\section{Cilj istraživanja}

Participacija, kao proces zadovoljavanja obrazovnih potreba, utiče na poboljšanje i dobijanje većih kompetencija, povećava zapošljivost i mobilnost na savremenom tržištu rada, kao i ostvarivanje socijalne inkluzije. Kako smo već isticali, smatramo da je vrlo značajno da svako društvo odnosno lokalna zajednica identifikuje glavne barijere participacije odraslih u obrazovanju. Njihova identifikacija i savladavanje nesumnjivo utiče na povećanje stope participacije, koja je izrazito niska u Crnoj Gori kao i u zemljama u regionu. Polazeći od prethodnih istraživanja opredijelili smo se da cilj istraživanja odredimo dvostruko:

- utvrditi hijerarhiju barijera odraslih za učenje;

- utvrditi da li socijalno-demografska obilježja determinišu barijere obrazovanja i nivo obrazovnog osujećenja.

Imajući u vidu prethodno formulisan cilj, hipoteze našeg istraživanja definisali smo na sljedeći način:

- pretpostavlja se da su na vrhu hijerarhije barijera egzistencijalni problemi;

- $\quad$ pretpostavlja se da neka socijalno-demografska obilježja determinišu barijere obrazovanja i indeks obrazovnog osujećenja odraslih.

Istraživački uzorak obuhvatio je 251 ispitanika sa teritorije opštine Nikšić. Za navedeni uzorak opredijelili smo se iz tog razloga što Nikšić smatramo tipičnom sredinom koja je karakteristična za veći dio Crne Gore 
(dakle namjerno smo izbjegli Podgoricu, koja predstavlja atipičan primjer i u velikoj mjeri se razlikuje od ostalih gradova u Crnoj Gori). Osim toga, za navedeni uzorak opredijelili smo se i zbog materijalno-tehničkih, prostornih i vremenskih ograničenja,jer smo na taj način olakšali organizaciju realizovanog istraživanja. Budući da su istraživanjem obuhvaćeni samo odrasli sa teritorije opštine Nikšić, realno je očekivati da bi rezultati bili objektivniji, potpuniji i pouzdaniji da smo istraživanjem obuhvatili i ostale regije Crne Gore (sjevernu, primorsku i još neke gradove centralne regije).

Instrument smo koncipirali na osnovu rezultata prethodnih istraživanja, čijom smo se analizom bavili. U prvom dijelu upitnika od ispitanika se tražilo da preciziraju neke opšte lične podatke (pol, godine starosti, nivo obrazovanja...). Zatim, u drugom dijelu instrumenta od ispitanika se tražilo da procijene vrijednost navedenih tvrdnji, koje su u vezi sa barijerama obrazovanja, ocjenom od 1 do $5, \mathrm{~s}$ tim što je ocjena 1 predstavljala najnižu, a ocjena 5 najvišu vrijednost.

\section{Interpretacija i diskusija dobijenih rezultata}

Najprije smo utvrdili hijerarhiju barijera obrazovanja odraslih, a zatim smo nastojali da utvrdimo da li postoji statistički značajna povezanost između seta socijalno-demografskih obilježja ispitanika i barijera obrazovanja odraslih. Na kraju, odlučili smo da izračunamo ukupni nivo obrazovnog osujećenja naših ispitanika i da ih svrstamo u tri kategorije: ispitanici koji imaju nizak, umjeren i visok nivo (indeks) obrazovnog osujećenja, a nakon toga da utvrdimo da li postoji statistički značajna korelacija između indeksa obrazovnog osujećenja i socijalno-demografskih obilježja ispitanika.

\section{Hijerarhija barijera obrazovanja odraslih}

Kako je i definisano ciljem istraživanja, najprije smo se bavili hijerarhijom barijera obrazovanja odraslih. Nadalje smo interesovanje usmjerili na hijerarhije barijera obrazovanja zaposlenih i nezaposlenih, kako bismo uočili moguće razlike i sličnosti i pristupili njihovoj analizi i diskusiji o njima.

Dobijeni podaci poduzetog istraživanja nam pokazuju da primarno mjesto u hijerarhiji barijera obrazovanja odraslih zauzima nedostatak novca. Zatim se nedostatak vremena, odnosno previše obaveza na poslu i u porodici vidi kao značajna barijera obrazovanja. Nakon toga se, po intenzitetu, izdvaja nedostatak interesantnih (praktičnih) programa kao faktor koji determiniše neparticipaciju odraslih u obrazovanju. Visok rang u hijerarhiji barijera obrazovanja odraslih 
(4. mjesto) zauzima nedostatak institucija koje nude programe obrazovanja namijenjene odraslima. Nadalje slijede barijere: zadovoljstvo postojećim znanjem, nemogućnost upotrebe stečenog znanja, neisplativost obrazovanja, nedostatak informacija o mogućnostima obrazovanja, godine starosti kao nepogodno vrijeme za učenje, nedostatak interesovanja, udaljenost institucije, nedovoljno praktična vrijednost obrazovanja, obrazovanje ne pričinjava zadovoljstvo, nedostatak samopouzdanja. $\mathrm{Na}$ dnu hijerarhije su barijere koje se tiču neujednačenosti grupe sa kojom pojedinac uči i nedostatak podrške od porodice.

Kako nam pokazuju prethodni podaci, na vrhu hijerarhije barijera su upravo određeni egzistencijalni problemi - primarno mjesto zauzimaju nedostatak novca i nedostatak vremena. I brojna druga empirijska istraživanja potvrđuju da su upravo ovo glavne barijere participacije odraslih u učenju i obrazovanju. Odrasli su najčešće prinuđeni da sami investiraju u obrazovanje, tj. najčešće su u situaciji da sami snose troškove obrazovnih aktivnosti, jer poslodavci i lokalne zajednice često nijesu spremni da ulažu sredstva (novac) u obrazovanje odraslih. Stoga je i opravdano da barijera nedostatak novca ima najviši rang u hijerarhiji barijera. Nedostatak vremena je druga najznačajnija barijera obrazovanja odraslih. Zapravo, previše obaveza na poslu, i briga o djeci su zaista česti razlozi neparticipacije, što potvrđuju rezultati brojnih empirijskih studija. Savremen način života odraslih donio je i izmijenjeno radno vrijeme, tako da pojedinci sve manje imaju slobodnog vremena koje bi mogli iskoristiti za različite obrazovne aktivnosti. Visoko mjesto (rang) u hijerarhiji barijera obrazovanja zauzimaju nedostatak interesantnih programa i nedostatak institucija koje nude obrazovne programe namijenjene odraslima. Institucionalne barijere su čest faktor osujećenja participacije odraslih u obrazovanju. U mnogim sredinama ne postoji dovoljan broj institucija, koje imaju savremene, kvalitetne obrazovne programe. Dakle, svaka društvena zajednica bi trebalo da razvije institucionalnu infrastrukturu obrazovanja odraslih, i da programi koje nude budu utemeljeni na potrebama privrede, ekonomije, tržišta rada $i$, svakako, pojedinca. Zadovoljstvo postojećim znanjem takođe ima visok rang u hijerarhiji barijera (5. pozicija). Nerijetko pojedinci smatraju da imaju dovoljno znanja koje im je potrebno za obavljanje određenih radnih zadataka. Međutim, ako se osvrnemo na promjene koje se intenzivno dešavaju u svim sferama života, i ako uzmemo u obzir činjenicu da upravo zbog tih promjena čovjekova znanja zastarijevaju, onda ne možemo opravdati stav da pojedinac može biti zadovoljan znanjem koje ima. Stoga smatramo da bi trebalo pronaći puteve i načine za podizanje svijesti svih ljudi 
u našem društvu o potrebi i neizbježnosti doživotnog učenja. Nemogućnost upotrebe stečenog znanja, kao barijera participacije, može se prevazići ukoliko organizatori obrazovanja odraslih prate promjene i programe prilagođavaju potrebama pojedinaca. Osim toga, neisplativost obrazovanja je takođe značajan faktor osujećenja participacije. Odrasli zapravo moraju provjeriti da li će vrijeme i novac koji ulože u neku obrazovnu aktivnost biti isplativi, odnosno da li će moći da nadoknade uloženo vrijeme i novac, uzimajući u obzir godine koje su im preostale za ostvarivanje radnog odnosa. Nedostatak informacija o mogućnostima obrazovanja zauzima središnje mjesto u hijerarhiji barijera obrazovanja odraslih. Često ljudima nijesu dostupne informacije o mogućnostima obrazovanja, o postojanju institucija za obrazovanje odraslih i programima koje nude. Upravo bi ovo moglo biti od značaja za organizatore obrazovanja odrsalih da na bolji način i putem medija promovišu svoje programe kako bi se broj participanata povećao. U hijerarhiji nadalje slijede barijere koje se tiču stavova i percepcije ispitanika o obrazovanju. $\mathrm{Na}$ dnu hijerarhije su, kako smo već istakli, neujednačenost obrazovnih grupa i nedostatak podrške porodice.

Kako smo već istakli, nadalje nas je u istraživanju zanimalo da li postoji razlika u rangiranju barijera obrazovanja kada ispitanike svrstamo u kategorije zaposlenih i nezaposlenih.

Analizirajući dobijene podatke, uočavamo da postoje izvjesne razlike u rangiranju barijera obrazovanja kada ispitanike svrstavamo u dvije kategorije - zaposleni i nezaposleni. Naime, zaposleni najviši rang dodjeljuju barijeri nedostatak vremena, dok je ona kod nezaposlenih na 7. poziciji (ispitanici su ponuđene barijere rangirali od 1. do 16. pozicije). Zapravo, zaposleni s obzirom na radne uloge i angažovanost i porodične obaveze imaju manje vremena za participiranje u obrazovanju u odnosu na nezaposlene, koji imaju više vremena samim tim što nijesu u radnom odnosu, te i ovu barijeru opravdano različito ranguju. Za obje kategorije ispitanika, nedostatak novca se ističe kao izrazito značajna barijera obrazovanja. Razumljivo je da nezaposleni - oni koji nemaju određene prihode, nedostatak novca procjenjuju kao ključni faktor osujećenja participacije u obrazovanju. Kako smo i ranije isticali, odrasli najčešće moraju sami da investiraju u obrazovanje, te je ovaj faktor zaista čest uzrok neparticipacije, što potvrđuju i rezultati prethodnih istraživanja. I zaposlenima je nedostatak novca jedna od ključnih barijera oni moraju da obezbjeđuju egzistenciju sebi i svojim članovima porodice, a imajući u vidu prosječan lični dohodak u našoj zemlji (prosječna neto zarada u ulu 2012. godine iznosila je 480 eura $)^{5}$, ne iznenađuje nas ovakvo rangiranje

5 www.monstat.org. Dostupno: [15. 6. 2012.]. 
barijere nedostatak novca, jer je vrlo teško izdvojiti određena sredstva za obrazovne aktivnosti. Sličnosti su u rangiranju institucionalnih barijera koje su u vezi sa nedostatkom institucija koje nude programe namijenjene odraslima i nedostatkom interesantnih i praktičnih programa. Upravo nam to ukazuje da na teritoriji opštine Nikšić, prema mišljenju naših ispitanika, ne postoji dovoljan broj institucija i različitih obrazovnih programa, što svakako zahtijeva posebnu i dublju objektivnu analizu. Nezaposleni visoko ranguju i barijeru nemogućnost upotrebe stečenog znanja. Upravo zbog nemanja posla, ovi ispitanici ne vide mogućnost upotrebe stečenog znanja. Sličnosti se ogledaju u rangiranju barijera koje se tiču nedostatka samopouzdanja, neujednačenosti obrazovne grupe i podrške porodice, koje se ujedno nalaze na dnu hijerarhije barijera i kod zaposlenih i nezaposlenih ispitanika.

Uzimajaću u obzir prvih pet barijera iz hijerarhije barijera nezaposlenih lica, a potpuno svjesni rizika pretjerane simplifikacije, mogli bismo kazati da profil potencijalnog participanta u obrzovanju odraslih u Nikšiću izgleda ovako: nema novca, nema programe, nema institucije, ne može da upotrijebi stečeno znanje i uglavnom je zadovoljan znanjem koje posjeduje.

\section{Povezanost socijalno-demografskih obilježja i barijera obrazovanja odraslih}

Tokom istraživanja nastojali smo da utvrdimo da li postoji povezanost između određenih socijalno-demografskih obilježja ispitanika i barijera obrazovanja odraslih. Upravo rezultati brojnih empirijskih studija pokazuju da su često barijere obrazovanja odraslih, kao i motivi, determinisani različitim karakteristikama ispitanika, odnosno polom, godinama starosti, nivoom obrazovanja i sl. Shodno tome, naša namjera je bila da utvrdimo povezanost ovih varijabli na uzorku koji smo odabrali.

\section{Godine starosti i barijere obrazovanja odraslih}

Rezultati do kojih smo došli tokom istraživanja pokazuju da postoji korelacija između godina starosti i barijere - smatram da moje godine nijesu pogodne za učenje. Zapravo, odgovori respondenata pokazuju da ispitanici koji su iznad 41 godine starosti navedenu barijeru vrednuju visokim ocjenama, dok ispitanici mlađih godina ovu barijeru ocjenjuju najnižim ocjenama. Dobijeni podaci ukazuju da je kod nas još uvijek dominantan kulturni obrazac da je učenje namijenjeno mladima, tj. da odrasli ljudi nemaju sposobnosti i mogućnosti za učenje. Ovakav stav, kako je poznato, zastupale su pristalice tzv. 
teorije plastičnosti. Međutim, Torndajk, američki psiholog, eksperimentalnim putem je dokazao da odrasli ljudi sa godinama starosti ne gube sposobnosti za učenje, i time opovrgao prethodno pomenute tvrdnje . Ali, rezultati do kojih smo došli pokazuju da dosta velik broj ispitanika, koji pripadaju grupi starijih odraslih, smatra da su godine starosti velika barijera, odnosno faktor osujećenja i ometanja njihove participacije u obrazovnim aktivnostima.

Dalje, rezultati istraživanja pokazuju da postoji povezanost između godina satrosti i barijere - obrazovanje mi ne pričinjava zadovoljstvo. Dobijeni podaci upućuju na opšti zaključak da sa porastom godina starosti obrazovanje postaje aktivnost koja je sve manje povezana sa zadovoljstvom. Zapravo rezultati istraživanja pokazuju da mlađi odrasli u veoma velikom procentu navedenu barijeru vrednuju najnižim ocjenama, za razliku od starijih odraslih. Mišljenja smo da stariji odrasli smatraju da njihove godine nijesu pogodne za učenje i obrazovanje, te samim tim obrazovanje im nerijetko i ne pričinjava zadovoljstvo. Za razliku od njih, mlađi odrasli obrazovanje doživljavaju kao aktivnost od koje imaju brojne koristi, te samim tim i svjesni su svih promjena koje se dešavaju u okruženju i koliko im učenje i obrazovanje pomaže u adaptaciji i praćenju tih promjena.

Nadalje, rezultati istraživanja pokazuju da postoji povezanost između godina starosti i barijere obrazovanja - nemam interesovanje za dalje učenje (nedostatak energije), u smislu da stariji odrasli pokazuju manji interes za učenje. Dakle, kod starijih odraslih ispitanika navedena barijera je zastupljenija kao faktor ometanja participacije u obrazovanju u odnosu na mlađe odrasle. Smatramo da mlađi odrasli imaju više interesovanja za obrazovne aktivnosti jer su na početku karijere, ili pak, ako su nezaposleni, dalje obrazovanje im može pomoći u dobijanju posla. Za razliku od njih, stariji odrasli nerijetko pokazuju nedovoljno interesovanja za participaciju u obrazovanju, a razlozi za to su brojni, jer je participacija u obrazovanju uslovljena životnom situacijom ispitanika i mogućnostima okruženja. Osim toga, stariji odrasli smatraju da učenje nije pogodna aktivnost u njihovim godinama i da je ono isključivo namijenjeno mlađima, te i ovo može biti jedan od razloga nedostatka interesovanja za participaciju u učenju i obrazovanju.

Dalje, odgovori respondenata pokazuju da postoji korelacija između godina starosti i barijere obrazovanja - neujednačenost grupe sa kojom učim (imamo različite sposobnosti i teško mi je da se uklopim). Dobijeni rezultati pokazuju da je neujednačenost obrazovne grupe značajnija barijera obrazovanja za starije odrasle, u odnosu na mlađe odrasle ispitanike. U praksi je obrazovne grupe odraslih zaista teško ujednačiti i postići homogenost grupe kao što je to 
slučaj sa djecom i mladima. Prije svega, odrasli ljudi koji participiraju u nekoj obrazovnoj aktivnosti su različitih godina starosti, pola, nivoa obrazovanja, profesije, socijalnog statusa i sl. te je samim tim i jasno zašto je teško sasvim ujednačiti obrazovne grupe. No, organizatori obrazovnih programa bi trebalo da nastoje da postignu homogenost u što većoj mjeri. Kako nam rezultati istraživanja pokazuju, stariji odrasli neujednačenost grupe sa kojom uče ocjenjuju kao veoma značajan faktor osujećenja participacije u odnosu na mlađe odrasle. Zapravo, poznate su fiziološke promjene koje se dešavaju u odrasloj dobi, te samim tim stariji ljudi opažaju, misle i reaguju mnogo sporije u odnosu na mlađe. Stoga i u konkretnoj obrazovnoj aktivnosti za učenje, obavljanje određenih zadataka, potrebno im je više vremena i objašnjenja u odnosu na mlađe, što je svakako barijera prilikom učenja u grupi, pogotovo u heterogenoj, s obzirom na godine starosti.

Nadalje, rezultati istraživanja pokazuju da postoji statistički značajna povezanost između godina starosti i barijere - ne vidim svrhu i praktičnu vrijednost obrazovanja. Rezultati do kojih smo došli ukazuju da stariji odrasli nemogućnost upotrebe stečenog znanja ocjenjuju kao značajnu barijeru participacije u odnosu na mlađe odrasle. Mišljenja smo da stariji odrasli, s obzirom na godine starosti, smatraju da znanje koje bi dobili uključivanjem u neku obrazovnu aktivnost ne mogu sasvim iskoristiti. Šta to zapravo znači? Stariji odrasli su pri kraju radnog vijeka, te samim tim pitaju se kakva je svrha njihovog obrazovanja i da li će uloženo vrijeme, novac, energija biti isplativi, odnosno da li će im obrazovanje donijeti toliko koristi kako bi mogli nadoknaditi troškove uložene u obrazovanje. Osim toga, postoji mogućnost da obrazovni programi nijesu dovoljno praktični, da ih ne mogu upotrijebiti u određenoj radnoj situaciji. Za razliku od njih, mlađi odrasli, kako smo više puta isticali, s obzirom da su na početku karijere imaju mnogo više vremena da stečeno znanje iskoriste, primijene, te da im bude isplativo ulaganje $u$ obrazovanje. Stoga je sasvim prirodna razlika koja postoji u odgovorima između starijih i mlađih odraslih.

\section{Povezanost nivoa obrazovanja i barijera obrazovanja odraslih}

Rezultati istraživanja pokazuju da nivo obrazovanja determiniše određene barijere obrazovanja odraslih. Prilikom analize i inetrpretacije dobijenih rezultata nijesmo uzimali u obzir odgovore ispitanika koji imaju nepotpunu ili završenu osnovnu školu, jer je njihov broj, koji je uzorkom obuhvaćen, u velikoj mjeri manji od broja ispitanika sa završenom srednjom ili visokom školom. 
Dobijeni podaci ukazuju da postoji povezanost između nivoa obrazovanja i barijere - nedostatak podrške porodice u smislu da ispitanici sa višim nivoom obrazovanja u najvećoj mjeri porodicu ne doživljavaju kao faktor ometanja participacije u učenju i obrazovanju. Dakle, ispitanici koji imaju završen zanat ili srednju školu, barijeru - nedostatak podrške porodice, ocjenjuju kao značajan faktor osujećenja njihove participacije u obrazovnim aktivnostima. Za razliku od njih, za ispitanike sa završenom višom ili visokom školom ova barijera nije toliko značajna ili pak u mnogo nižem procentu u odnosu na prethodnu grupu ispitanika. Mišljenja smo da pojedinci sa završenom visokom školom žive u porodicama koje razumiju njihove uloge na poslu i odgovornosti, te samim tim pružaju im podršku za kontinuirano obrazovanje, usavršavanje, cjelokupno za participaciju u učenju i obrazovanju. Na drugoj strani, pitamo se zašto ispitanicima sa završenom srednjom školom ili zanatom nedostaje podrška porodice? Ili pak zašto nedostaje u većoj mjeri u odnosu na ispitanike sa visokim nivoom obrazovanja? Moguće je da se porodice ispitanika sa nižim nivoom obrazovanja nalaze u nepovoljnijoj socijalno-ekonomskoj situaciji, te samim tim izostaje podrška za uključivanje u obrazovanje, prije svega zbog brojnih problema, kako finansijskih tako i socijalnih. Ove porodice prije očekuju angažman od svojih članova u nekim profesionalno-radnim aktivnostima, radi sticanja dodatne zarade nego $u$ aktivnostima obrazovanja.

Nadalje, rezultati istraživanja pokazuju da postoji statistički značajna korelacija kada je u pitanju nivo obrazovanja i barijera - smatram da moje godine nijesu pogodne za učenje. Ukoliko uporedimo rezultate navedenih grupa, uočavamo da ispitanici sa nižim nivoom obrazovanja u mnogo većem procentu navedenu barijeru vrednuju visokim ocjenama (4 i 5) u odnosu na ispitanike sa višim nivoom obrazovanja. Dok se za ocjenu 1 u mnogo većem procentu izjašnjavaju ispitanici sa visokim nivoom obrazovanja.

Dalje, odgovori ispitanika pokazuju da postoji povezanost između nivoa obrazovanja i barijere - obrazovanje mi ne pričinjava zadovoljstvo. Naime rezultati poduzetog istraživanja pokazuju da je i ova barijera značajnija za ispitanike sa nižim nivoom obrazovanja, u odnosu na ispitanike koji imaju završenu višu ili visoku školu.

Dakle, ispitanici sa nižim nivoom obrazovanja barijere - smatram da moje godine nijesu pogodne za učenje i obrazovanje mi ne pričinjava zadovoljstvo, ocjenjuju kao jake faktore osujećenja participacije u obrazovanim aktivnostima $u$ odnosu na ispitanike sa višim nivoom obrazovanja, tj. rezultati istraživanja pokazuju da postoji značajna razlika u odgovorima 
između navedenih grupa ispitanika. Smatramo da su ispitanici sa nižim nivoom obrazovanja skloniji da prihvataju predrasude koje postoje u nekom društvu, pa je i jedna od njih ta da je obrazovanje namijenjeno djeci i mladima i da odrasli nemaju sposobnosti i mogućnosti za učenje. Osim toga, kao što je ranije naglašeno ispitanici sa višim nivoom obrazovanja, nerijetko zbog poslova koje obavljaju su ,prinuđeni,, da se profesionalno usavršavaju i uključuju u različite obrazovne aktivnosti, dok ispitanici sa nižim nivoom obrazovanja obavljaju poslove nižeg socijalnog statusa, te samim tim imaju i mnogo manje mogućnosti da se stručno usavršavaju i uključuju u učenje i obrazovanje iz raznovrsnih potreba koje zahtijeva radno mjesto. Mišljenja smo da su ispitanici sa visokim nivoom obrazovanja svjesniji neophodnosti učenja u svim periodima života, kako bi se mogli prilagoditi promjenama koje se dešavaju u svijetu, te i njihovom poslovnom i porodičnom okruženju. Dok ispitanici sa nižim nivoom obrazovanja vjerovatno prihvataju stav da se sa završetkom formalnog školovanja završava i njihovo učenje. Osim toga, dobijeni rezultati pokazuju da postoji razlika u odgovorima ispitanika kada je u pitanju barijera - obrazovanje mi ne pričinjava zadovoljstvo. Uočavamo da ispitanici sa nižim nivoom obrazovanja učenje i obrazovne aktivnosti u manjoj mjeri doživljavaju kao zadovoljstvo u odnosu na ispitanike sa višim nivoom obrazovanja. Smatramo da ispitanici sa nižim obrazovnim nivoom imaju više finansijskih, i svih drugih problema u odnosu na ispitanike sa visokim nivoom obrazovanja. Shodno tome, obrazovanje posmatraju kao sredstvo koje im može pomoći da poboljšaju vlastiti socijalno-ekonomski položaj i zbog zaokupljenosti egzistencijalnim problemima nijesu u mogućnosti da spoznaju sve ostale vrijednosti obrazovnih aktivnosti. Sa druge strane, ispitanici sa visokim nivoom obrazovanja, svjesni svih koristi koje donose učenje i obrazovanje, a u skladu sa nivoom obrazovanja obavljaju poslove koji imaju visok socijalni status i društveni ugled, imaju mnogo manje egzistencijalnih problema, te samim tim u obrazovanju otkrivaju druge vrijednosti, žele da dostignu samoaktualizaciju, da maksimalno razviju svoje potencijale i ličnost u cjelini. Upravo zbog navedenih razloga obrazovanje doživljavaju kao aktivnost koja im donosi mnogo duhovnog bogatstva, osim neposrednih koristi. Za razliku od njih, smatramo da su ispitanici sa nižim nivoom obrazovanja najčešće primorani da participiraju u obrazovanju zbog nekih egzistencijalnih problema, pa usljed takve situacije i ne mogu da spoznaju ostale dobrobiti samog procesa učenja.

Nadalje, rezultati istarživanja pokazuju da postoji korelacija kada su u pitanju nivo obrazovanja i barijera - nedostatak samopouzdanja i nepovjerenje 
$u$ vlastite sposobnosti. Dakle, uočljivo je da za ispitanike sa visokim nivoom obrazovanja nedostatak samopouzdanja, odnosno nepovjerenje u vlastite sposobnosti, ne predstavlja značajnu barijeru obrazovanja, dok je za ispitanike sa završenim zanatom ili srednjom školom ipak u većoj mjeri ocijenjena kao faktor ometanja participacije u programima obrazovanja.

Rezultati istraživanja pokazuju da postoji povezanost kada je u pitanju nivo obrazovanja i barijera - neujednačenost grupe sa kojom učim. Podaci do kojih smo došli pokazuju da ispitanici sa nižim nivoom obrazovanja daju ocjene 2, 3, 4 i 5 u mnogo većem procentu u odnosu na ispitanike sa višim nivoom obrazovanja, koji imaju veći procenat za ocjenu 1, kao najnižu vrijednost.

Dobijeni rezultati potvrđuju da nivo obrazovanja determiniše brojne barijere obrazovanja odraslih. Rezultati poduzetog istraživanja pokazuju nam da postoji značajna razlika u odgovorima između ispitanika sa završenom srednjom školom i ispitanika sa završenom višom ili visokom školom. Zapravo, za ispitanike sa nižim nivoom obrazovanja nedostatak samopouzdanja, kao i neujednačenost grupe sa kojom uče su značajnije barijere u odnosu na ispitanike sa završenom višom ili visokom školom. Dakle, ispitanici sa nižim nivoom obrazovanja imaju manje povjerenja $\mathrm{u}$ vlastite sposobnosti, što je uglavnom uslovljeno nivoom obrazovanja. Upravo zbog različitih sposobnosti participanata, obrazovna grupa može biti značajna barijera obrazovanja odraslih. Mišljenja smo da se ispitanici sa nižim nivoom obrazovanja, upravo zbog svog inicijalnog obrazovanja, (ne) uspjeha tokom školovanja, teže prilagođavaju u različitim situacijama koje su u vezi sa obrazovanjem, te samim tim nerijetko izostaje i samopouzdanje koje je potrebno za uspješan proces učenja. Prirodno je da pojedinci sa visokim nivoom obrazovanja imaju dovoljno samopouzdanja i povjerenja u vlastite sposobnosti, i da se lakše prilagođavaju različitim obrazovnim grupama.

\section{Bračni, porodični i radni staus i barijere obrazovanja odraslih}

Odgovori respondenata pokazuju da bračni status determiniše neke barijere obrazovanja odraslih. Naime, rezultati istraživanja ukazuju da postoji korelacija između bračnog statusa i nedostatka vremena kao barijere obrazovanja. Rezultati pokazuju da je nedostatak vremena značajnija barijera za ispitanike koji su u braku, u odnosu na one koji nijesu. Dakle, nedostatak vremena, kao barijera obrazovanja, više je izražena kod ispitanika koji su braku. Zapravo, previše obaveza na poslu i u porodici su svakako jak faktor osujećenja participacije u obrazovnim aktivnostima. Prirodno je 
da ispitanici koji su u braku, prije svega zbog obaveza u porodici (osim onih na poslu), imaju zaista manje slobodnog vremena koje bi mogli koristiti za zadovoljavanje obrazovnih potreba, tj. participaciju u učenju i obrazovanju. Stoga bi organizatori obrazovnih programa trebalo da imaju u vidu obaveze potencijalnih participanata i obrazovne programe prilagode njihovim obavezama, a ukoliko je moguće u sklopu centara za obrazovanje odraslih i za vrijeme časova organizuju neke aktivnosti za djecu čiji su roditelji uključeni u konkretnu obrazovnu aktivnost.

Nadalje, rezultati istraživanja pokazuju da postoji povezanost između porodičnog statusa, roditeljstva (podatak da li imaju djecu ili ne) i barijere obrazovanja - nedostatak vremena (previše obaveza na poslu i u porodici). Naime, za ispitanike koji imaju djecu, barijera - nedostatak vremena, odnosno previše obaveza na poslu i u porodici značajnija je u odnosu na ispitanike koji nemaju djecu. Dakle, uočljivo je da postoji značajna razlika u ocjenjivanju barijere - nedostatak vremena između ispitanika koji imaju i onih koji nemaju djecu. Prirodno je da ispitanici koji imaju djecu u mnogo većem procentu daju ocjenu $5 \mathrm{u}$ odnosu na ispitanike koji nemaju djecu, jer zaista imaju više obaveza u porodici, što uzrokuje sve manje slobodnog vremena koje bi mogli koristiti u obrazovne svrhe.

Dalje, rezultati istraživanja pokazuju da postoji korelacija kada je u pitanju roditeljstvo i barijera - smatram da moje godine nijesu pogodne za učenje. Dobijeni podaci ukazuju da postoji značajna razlika u ocjenjivanju barijere - smatram da moje godine nijesu pogodne za učenje, između ispitanika koji imaju i onih koji nemaju djecu. Mišljenja smo da ispitanici koji imaju djecu, upravo zbog obaveza i odgovornosti koje imaju u porodici i na poslu, navedenu barijeru doživljavaju kao značajan faktor osujećenja participacije u obrazovnim aktivnostima. Stav da je obrazovanje namijenjeno djeci i mladima, a ne i odraslima, vjerovatno je dodatno potkrijepljen činjenicom da imaju djecu koja se školuju, te nije ,prirodno,, da se roditelji i djeca istovremeno obrazuju. Za razliku od njih, ispitanici koji nemaju djecu, u dosta manjoj mjeri navedenu barijeru ocjenjuju kao faktor ometanja participacije u učenju i obrazovanju.

Nadalje, rezultati istraživanja pokazuju da postoji povezanost između radnog statusa (zaposlenost/nezaposlenost) i barijere nedostatak vremena, odnosno previše obaveza na poslu i u porodici. Zapravo, dobijeni rezultati pokazuju da ispitanici koji su zaposleni u mnogo većoj mjeri nedostatak vremena ocjenjuju kao važnu barijeru obrazovanja u odnosu na ispitanike koji su nezaposleni. Prirodno je i očekivano da ispitanici koji su zaposleni, 
nedostatak vremena ocijene kao značajnu barijeru participacije u obrazovanju, u odnosu na nezaposlene. Zaposlenje i druge obaveze umanjuju slobodno vrijeme koje bi pojedinci mogli da investiraju u obrazovne aktivnosti. Na drugoj strani, nezaposleni imaju mnogo više slobodnog vremena koje bi upravo mogli racionalno da koriste time što će se uključiti u neku obrazovnu aktivnost, a koja im može biti od koristi u traženju ili pak dobijanju posla. Smatramo da ova barijera sve više dolazi do izražaja u savremenom društvu, gdje se broj radnih sati povećava do te mjere da čovjek sve manje ima vremena koje bi provodio sa porodicom - koliko onda ostaje slobodnog vremena koje bi se moglo iskoristiti za obrazovanje i učenje?

\section{Profesionalna pripadnost i barijere obrazovanja odraslih}

Rezultati poduzetog istraživanja pokazuju da profesija determiniše neke barijere obrazovanja odraslih. Naime, odgovori ispitanika ukazuju da postoji korelacija između profesionalne pripadnosti i barijere obrazovanja - porodica to ne želi (nedostatak podrške). Dakle, odgovori respondenata pokazuju da je barijera - nedostatak podrške porodice za participaciju u obrazovnim aktivnostima značajnija za profesiju radnika, u odnosu na stručnjake, inženjere ili prosvjetne radnike. Smatramo da se profesija i navedena barijera mogu povezati sa nivoom obrazovanja. Zapravo, porodice stručnjaka, inženjera, prosvjetnih radnika su naviknute na činjenicu da se njihovi članovi moraju kontinuirano obrazovati kako bi mogli da napreduju i sačuvaju ugled i status koji imaju u određenoj profesiji. Dok na drugoj strani, porodice radnika ili administrativnog osoblja, pretpostavljamo, imaju lošiju socijalno-ekonomsku poziciju, te samim tim mnogo manje interesovanja za obrazovanje svojih članova. Prethodno smo isticali da određene profesije zahtijevaju permanentno profesionalno usavršavanje i praćenje promjena $u$ struci. Shodno tome, sa sigurnošću tvrdimo, da će porodice pojedincima koji su ,prinuđeni,, na kontinuirano stručno usavršavanje, radi napredovanja u profesiji, dobijanja boljeg radnog mjesta, ili zadržavanja pozicije koju imaju, pružiti podršku za participaciju u učenju i obrazovanju, jer je to neophodno za egzistenciju njihovih članova.

Nadalje, rezultati istraživanja pokazuju da postoji povezanost kada je u pitanju profesija i barijera obrazovanja - smatram da moje godine nijesu pogodne za učenje. Naime, dobijeni podaci ukazuju da je barijera - smatram da moje godine nijesu pogodne za učenje, značajniji faktor osujećenja participacije za radnike, a nakon njih i administrativno osoblje u odnosu na inženjere, prosvjetne radnike i stručnjake. Budući da profesiju možemo 
povezati sa nivoom obrazovanja, uočavamo da je radnici u neposrednoj proizvodnji i administrativno osoblje (ispitanici sa nižim nivoom obrazovanja) u mnogo većem procentu vrednuju ocjenom 5 , u odnosu na ispitanike sa visokim nivoom obrazovanja, $\mathrm{tj}$. inženjere, prosvjetne radnike i stručnjake. Svakako se ovo može povezati i sa poslovima koje obavljaju, u smislu da su ispitanici iz profesija koje zahtijevaju visok nivo obrazovanja često i prinuđeni da participiraju u obrazovnim aktivnostima upravo zbog profesije i posla koji obavljaju, te samim tim godine starosti ne mogu doživljavati kao važnu barijeru obrazovanja. Na drugoj strani, radnici i administrativno osoblje (ispitanici sa nižim nivoom obrazovanja), imaju manje mogućnosti da napreduju u profesiji, poslovi koje obavljaju su najčešće manje zahtjevni i ne iziskuju kontinuirano učenje, te stav da odraslo doba nije pogodno za učenje lako prihvataju.

Dalje, rezultati istraživanja pokazuju da postoji povezanost između profesije i barijere obrazovanja - neujednačenost grupe sa kojom učim. $\mathrm{Na}$ osnovu dobijenih podataka uočavamo da je neujednačenost grupe, kao barijera obrazovanja, značajnija za radnike i administrativno osoblje u odnosu na inženjere, prosvjetne radnike i stručnjake. Mišljenja smo da je povezanost neujednačenosti obrazovne grupe i profesije jednaka korelaciji nivoa obrazovanja i neujednačenosti obrazovne grupe. Zapravo, ispitanici sa nižim inicijalnim nivoom obrazovanja (radnici i administrativno osoblje) teže se prilagođavaju različitim obrazovnim grupama u odnosu na ispitanike s visokim nivoom obrazovanja.

Tokom obrade podataka odlučili smo da nezavisnu varijablu - profesonalna pripadanost, operacionalizujemo na dva indikatora: radnici i stručnjaci. Dakle, u kategoriju radnika svrstali smo radnike u neposrednoj proizvodnji, administrativno osoblje i ostale, a u kategoriju stručnjaka: inženjerskotehničke kadrove, prosvjetne radnike i stručnjake (pravnike i ekonomiste). Imali smo namjeru da utvrdimo da li postoji korelacija između profesije, kada je operacionalizovana na dva indikatora, i barijera obrazovanja odraslih.

Rezultati istraživanja pokazuju da postoji korelacija između profesije i barijere - obrazovanje mi ne pričinjava zadovoljstvo. Dakle, dobijeni podaci ukazuju da je za radnike navedena barijera značajan faktor osujećenja participcije u učenju i obrazovanju, u odnosu na stručnjake.

Nadalje, rezultati istraživanja pokazuju da postoji korelacija kada je u pitanju profesija i barijera obrazovanja-nemam interesovanje za dalje učenje. Odgovori respondenata nam pokazuju da je barijera obrazovanja odraslih nemam interesovanje za dalje učenje, važan faktor ometanja participacije 
u obrazovnim aktivnostima za kategoriju radnika u odnosu na kategoriju stručnjaka.

Prethodno navedeni podaci pokazuju da ispitanici koji su u grupi radnika barijere - obrazovanje mi ne pričinjava zadovoljstvo i nemam interesovanje za dalje učenje, izdvajaju kao značajnije faktore osujećenja participacije u obrazovanju, za razliku od ispitanika koji pripadaju kategoriji stručnjaka. Mišljenja smo da navedene barijere determiniše nivo obrazovanja koji se odražava kroz profesiju. Jer, radnici (ispitanici sa nižim nivoom obrazovanja) pokazuju da nemaju dovoljno interesovanja za dalje učenje i istovremeno obrazovanje im ne pričinjava zadovoljstvo. Zapravo, njihove profesije (poslovi koje obavljaju) ne omogućavaju im dalje napredovanje, i poboljšanje socijalnog statusa, te samim tim nijesu ni zainteresovani za dalje učenje $i$ obrazovanje. Budući da su radnici u mnogo težoj socijalno-ekonomskoj poziciji u odnosu na stručnjake, trebalo bi poboljšati njihovo inicijalno obrazovanje i na taj način otvoriti mogućnost za napredovanje u profesiji, odnosno dobijanje boljeg radnog mjesta. Stručnjaci, tj. ispitanici sa visokim nivoom obrazovanja, prirodno je da pokazuju interesovanje za dalje učenje, i obrazovanje doživljavaju kao aktivnost koja im pričinjava zadovoljstvo. Oni su nerijetko „,prinuđeni,, da se kontinuirano usavršavaju zbog posla koji obavljaju. Međutim, smatramo da navedene barijere u najvećoj mjeri determiniše nivo obrazovanja, jer kako raste nivo obrazovanja tako rastu i obrazovni zahtjevi i potrebe. Shodno tome, i očekivana je razlika u odgovorima između navedenih kategorija ispitanika, tj. radnika i stručnjaka.

Dalje, rezultati poduzetog istraživanja pokazuju da postoji povezanost kada je u pitanju profesija i nedostatak samopouzdanja, kao barijera obrazovanja odraslih. Upravo podaci do kojih smo došli pokazuju da je za radnike nedostatak samopouzdanja, odnosno nepovjerenje u valstite sposobnosti, značajnija barijera obrazovanja u odnosu na stručnjake. Smatramo da stručnjaci zbog profesije i poslova koje obavljaju imaju jasniju sliku o vlastitim sposobnostima te samim tim i dovoljno samopouzdanja koje je potrebno da se uključe u neku obrazovnu aktivnost i da očekivane ishode učenja savladaju uspješno. Kako nam potvrđuju prethodno navedeni i prikazani rezultati poduzetog istraživanja, profesija u velikoj mjeri determiniše određene barijere obrazovanja odraslih. Postoje veoma velike razlike u ocjenjivanju barijera između različitih profesija i trebalo bi daljim istraživanjima tražiti i otkrivati uzroke koji dovode do toga. 


\section{Povezanost socijalno-demografskih obilježja i indeksa obrazovnog osujećenja}

Tokom istraživanja nastojali smo da saznamo koliki je ukupni indeks obrazovnog osujećenja ispitanika koji su obuhvaćeni uzorkom. Zapravo, sve ispitanike smo podijelili u tri kategorije: ispitanici koji imaju nizak, umjeren i visok nivo obrazovnog osujećenja. Nakon toga smo ispitali da li postoji značajna povezanost između određenih socijalno-demografskih obilježja i indeksa osujećenja ispitanika.

Dobijeni podaci pokazuju da je najviše ispitanika koji imaju umjeren nivo osujećenja, tj. njih 50.2\%, zatim $36.7 \%$ ispitanika koji imaju nizak nivo osujećenja i 13\% ispitanika koji imaju visok nivo osujećenja.

Dakle, polovina ispitanika koji su obuhvaćeni uzorkom imaju umjeren nivo osujećenja. Smatramo da 13\% ispitanika koji se izjašnjavaju da imaju visok nivo osujećenja nije zanemarljiv procenat. Poduzetim istraživanjem nastojali smo da utvrdimo hijerarhiju barijera obrazovanja odraslih kako bismo saznali koje su to ključne, najznačajnije barijere obrazovanja naših ispitanika. Rezultati do kojih smo došli mogu poslužiti u otklanjanju tih barijera kako bi se broj ispitanika koji imaju visok nivo osujećenja smanjio. Mišljenja smo da bi u nekim budućim istraživanjima pažnju trebalo usmjeriti na ispitanike koji imaju visok nivo osujećenja i kroz razgovor (intervju) otkriti koji su to njihovi glavni faktori osujećenja participacije u obrazovnim aktivnostima, kako bi nakon toga pojedinci, organizacije u kojima rade i zajednica u cjelini sistematski radili na otklanjanju barijera.

Kako smo već istakli, nakon dobijene strukture indeksa obrazovnog osujećenja nastojali smo da utvrdimo da li postoji povezanost sa nekim od socijalno-demografskih obilježja. Rezultati do kojih smo došli ukazuju da postoji korelacija kada su u pitanju indeks obrazovnog osujećenja i godine starosti.

Prethodno smo nezavisnu varijablu - godine starosti operacionalizovali na dva indikatora: ispitanici koji imaju od 20 do 40 godina i ispitanici koji su iznad 41 godine starosti. Analizirajući dobijene podatke uviđamo da mlađi odrasli u najvećem procentu imaju nizak, a stariji odrasli umjeren nivo obrazovnog osujećenja. Posebno se izdvaja razlika u procentima kada je $u$ pitanju visok i nizak nivo osujećenja. Naime, kod ispitanika iznad 41 godine starosti mnogo je veći procenat za visok nivo, a kod ispitanika od 20 do 40 godina starosti za nizak nivo osujećenja. Dakle, stariji odrasli cjelokupno imaju više barijera participacije u obrazovnim aktivnostima u odnosu na mlađe odrasle. Prije svega, stariji odrasli imaju mnogo manje vremena da 
sredstva i energiju koju su investirali u neku obrazovnu aktivnost „naplate,, tj. da im to obrazovanje bude isplativo. Osim toga, stariji odrasli se nerijetko i teže prilagođavaju u obrazovnoj grupi. Ukoliko već duže vrijeme nijesu bili uključeni u neku obrazovnu aktivnost, postoji strah od neuspjeha, nedovoljno povjerenja u sposobnosti i nedovoljno samopouzdanja. Sve ovo su barijere koje utiču na to da stariji odrasli imaju viši nivo osujećenja u odnosu na mlađe odrasle. Svakako, navedene rezultate ne treba generalizovati, mada brojne empirijske studije upravo navode razlike između mlađih i starijih odraslih i njihovu povezanost sa barijerama, a istovremeno i sa motivima obrazovanja.

Nadalje, rezultati istraživanja pokazuju da postoji povezanost između nivoa obrazovanja i indeksa obrazovnog osujećenja ispitanika. Prethodno smo nezavisnu varijablu - nivo obrazovanja - operacionalizovali na dva indikatora: osnovna škola/zanat/ srednja škola i viša/visoka škola. Dobijeni podaci ukazuju da ispitanici sa nižim nivoom obrazovanja u najvećem procentu imaju umjeren nivo osujećenja, a ispitanici sa visokim nivoom obrazovanja nizak nivo osujećenja. Dakle, podaci pokazuju da ispitanici sa nižim nivoom obrazovanja imaju mnogo više osujećenja, odnosno faktora koji ometaju participaciju u obrazovanju. Smatramo da je to prije svega zbog lošije socijalno-ekonomske pozicije koju imaju ovi pojedinci u odnosu na one koji su visokog nivoa obrazovanja. Osim toga, u skladu sa nivoom obrazovanja, obavljaju poslove koji su slabije plaćeni, imaju mnogo više različitih egzistencijalnih problema, te samim tim i zaista više barijera obrazovanja. Pored barijera koje su povezane sa egzistencijalnim problemima, nizak nivo obrazovanja determiniše i različite dispozicione barijere. Na primjer, rezultati poduzetog istraživanja pokazuju da ispitanici sa nižim nivoom obrazovanja kao veoma značajnu ocjenjuju barijeru nedostatak samopouzdanja, što svakako može biti povezano sa njihovim prethodnim iskustvom, obrazovnim postignućem, nivoom aspiracije i sl. Očigledno je da ispitanici sa nižim nivoom obrazovanja imaju više faktora koji ometaju njihovu participaciju u obrazovnim aktivnostima. Ovo saznanje može biti korisno za organizatore obrazovanja i za one koji su zaduženi za obrazovnu politiku odraslih kako bi mogli osmisliti startegiju za moguće i sistematsko prevazilaženje barijera obrazovanja kod ovog dijela populacije.

Dalje, odgovori ispitanika pokazuju da postoji korelacija kada je u pitanju roditeljstvo (podatak da li imaju djecu) i indeks obrazovnog osujećenja. Dakle, odgovori respondenata pokazuju da oni koji imaju djecu u mnogo većem procentu imaju visok nivo osujećenja u odnosu na ispitanike koji nemaju djecu. Postoji velika razlika u odgovorima kada je u pitanju nizak 
nivo osujećenja, koji je dominantniji kod pojedinaca koji nemaju djecu. Očekivano je da ispitanici koji imaju djecu istovremeno imaju i više barijera obrazovanja. Mišljenja smo da su neke barijere kao što su nedostatak vremena ili nedostatak novca primarne kod ispitanika koji imaju djecu. Respondenti koji imaju djecu, imaju i manje slobodnog vremena koje bi koristili za obrazovne aktivnosti. Pored toga, briga o djeci iziskuje i velika novčana sredstva, što opet utiče na nedostatak novca za investiranje u obrazovanje. Kako nam potvrđuju prethodni podaci, ispitanici koji imaju djecu, u najvećem procentu imaju umjeren nivo osujećenja, dok oni koji nemaju djecu imaju nizak nivo osujećenja.

Nadalje, rezultati istraživanja pokazuju da postoji korelacija između profesijei indeksa obrazovnog osujećenja. Nezavisnu varijablu-profesionalna pripadnost operacionalizovali smo na dva indikatora: radnici (radnici u neposrednoj proizvodnji, administrativno osoblje i ostali) i stručnjaci (inženjersko-tehnički kadrovi, prosvjetni radnici i stručnjaci). Rezultati istraživanja ukazuju da kod radnika dominira umjeren, dok kod stručnjaka nizak nivo obrazovnog osujećenja. Razlika u odgovorima ispitanika posebno je vidljiva kada je u pitanju visok i nizak nivo osujećenja. Dobijeni podaci potvrđuju da radnici imaju više faktora koji ometaju participaciju u obrazovnim aktivnostima u odnosu na stručnjake. Zapravo, profesija je povezana prije svega sa nivoom obrazovanja. Stoga stručnjaci obavljaju poslove koji su bolje plaćeni, te samim tim imaju manje egzistencijalnih problema u odnosu na radnike. Pored toga, stručnjaci imaju više realnih mogućnosti da napreduju u profesiji, da se stručno usavršavaju i da nakon zadovoljenja potreba nižeg reda ostvare i one više, kao što je samoaktualizacija. Imajući u vidu profesiju, i nivo obrazovanja, radnici imaju zaista više faktora koji ometaju njihovu participaciju u obrazovanju. Mišljenja smo da bi trebalo razviti mehanizme za otklanjanje barijera kod posebnih socijalnih kategorija, kao što su radnici.

\section{Zaključna razmatranja}

Rezultati poduzetog istraživanja pokazuju da najviši rang u hijerarhiji barijera ispitanici dodjeljuju nedostatku novca i nedostatku vremena. Dakle, riječ je o suštinskim problemima koji se odnose na čovjekovu egzistenciju. Uzimajući $\mathrm{u}$ obzir rezultate srodnih prethodnih istraživanja, u našem istraživanju pošli smo od pretpostavke da se na vrhu hijerarhije barijera obrazovanja nalaze egzistencijalni problemi, što potvrđuju i rezultati do kojih smo došli, te je samim tim naša polazna hipoteza vjerovatna.

Nadalje, rezultati do kojih smo došli pokazuju da godine starosti, nivo 
obrazovanja, profesija, bračni, porodični i radni status detreminišu brojne barijere obrazovanja odraslih. Pored toga, podaci do kojih smo došli pokazuju da najviše ispitanika ima umjeren nivo obrazovnog osujećenja. Međutim, $13 \%$ od ukupnog broja ispitanika ima visok nivo obrazovnog osujećenja i mišljenja smo da ovo nije ili ne bi trebao biti zanemarljiv procenat. Rezultati istraživanja pokazuju da postoji statistički značajna povezanost indeksa obrazovnog osujećenja sa godinama starosti, nivoom obrazovanja i profesijom. Dakle, rezultati poduzetog istraživanja koje smo prethodno sumirali pokazuju da je naša polazna pretpostavka da neka socijalno-demografska obilježja determinišu barijere obrazovanja i indeks obrazovnog osujećenja odraslih vjerovatna.

Kako smo već prethodno istakli, participacija odraslih u programima obrazovanja je vrlo kompleksan proces. Ukoliko neko društvo želi da postane društvo koje uči, koje svoju ekonomiju temelji i razvija na znanju, nužno se mora baviti barijerama obrazovanja odraslih. Dakle, najprije se mora raditi na identifikovanju ključnih barijera a onda sistematski pristupiti njihovom otklanjanju. Smatramo da se moraju perduzeti sve potrebne mjere kako bi se povećao broj pojedinaca koji participiraju u obrazovnim aktivnostima, a svakako se to najlakše može postići upravo identifikacijom i otklanjanjem faktora koji negativno utiču na sam proces obrazovanja odraslih. Ističemo da u našem društvu obrazovanje odraslih mora biti prepoznato kao važna karika cjelokupnog obrazovnog sistema jer je ono ključna komponenta i najočiglednija manifestacija doživotnog učenja, dakle ključni pokazatelj da li idemo putem društva koje uči.

\section{BARRIERS TO PARTICIPATION IN ADULT EDUCATION IN MONTENEGRO ${ }^{6}$}

\section{- Abstract -}

In a modern world, learning and education define the way of man's survival as well as social and individual development. We've been witnesses of everyday's growth of the educational needs of each individual, i.e. that the employment, the progress in one's profession, the change or keeping a workplace require induction into the learning and education process. It has

6 Excerpt from master's thesis. 
been known to us that the process of participation of adults into the education programmes is followed by various impediments, and the result of that is extremely low rate of participation in Montenegro, as well as in the other countries of the region. Therefore, this paper is directed towards perceiving the key impediments in the education of adults, in fact, the goal of the research was actually about establishing the impediments hierarchy and establishing a connection between a set of social-demographic characteristics and the educational impediments, as well as the level of educational disruption.

Key words: education of adults, educational impediments, participation.

\section{Literatura}

- Despotović, M. (2000): Igra potreba, Institut za pedagogiju i andragogiju Filozofskog fakulteta u Beogradu, Andragoško društvo Srbije, Beograd.

- Đukanović, R. (2008): Andragogija, Zavod za udžbenike i nastavna sredstva Podgorica, Podgorica.

- Komisija Evropske Zajednice, Komunikacija komisije, Obrazovanje odraslih: Nikad nije kasno za učenje, Brisel, 2006. (u časopisu: Andragoške studije, br. 2, (2007.), Institut za pedagogiju i andragogiju Beograd).

- Kulić, R. (1997): Sadržaj rada i obrazovanje, Institut za pedagogiju i andragogiju Filozofskog fakulteta u Beogradu, Beograd.

- Kulić, R., Despotović, M. (2005): Uvod u andragogiju, Svet knjige, Beograd.

- Rogers, A. (2003): Teaching Adults, Open University Press, Philadelphia.

- Savićević, D. (1989): Koncepcija obrazovnih potreba, Zavod za udžbenike i nastavna sredstva Beograd, Institut za pedagoška istraživanja Beograd, Katedra za Andragogiju Filozofskog fakulteta Beograd, Beograd.

- Savićević, D. (1991): Savremena shvatanja andragogije, Institut za pedagogiju i andragogiju Filozofskog fakulteta, Beograd.

- Savićević, D. (2000): Put ka društvu učenja, DP Đuro Salaj, JNIP Prosvetni pregled Beograd, Beograd.

- Savićević, D. (2011): Uvod u metodologiju andragogije, Visoka škola strukovnih studija za obrazovanje vaspitača „Mihailo Pavlov,” Vršac. 
- Tuijnman, A. Ed. (1996): International encyclopedia of adult education and training, „Pergamon,„, Oxford.

- Web izvori:

- Malhotra, N., Sizoo, S., Chorvat, V. (1999): Barriers to adult participation in undergraduate education, ,Adult Higer Education Alliance,

Dostupno na:

- www.ahea.org/files/pro1999malhotra.pdf [20. 5. 2102.];

- www.monstat.org. Dostupno: [15. 6. 2012.];

- www.stat.fi/til/aku/1995. Dostupno: [19. 5. 2012.]. 


\section{UPUTSTVO ZA AUTORE PRILOGA}

Časopis Obrazovanje odraslih objavljuje originalne stručne i naučne radove, saopćenja, recenzije i informacije iz rada centara za edukaciju odraslih u našoj zemlji. Časopis objavljuje i aktuelne članke iz stranih časopisa, kao i informacije o značajnim događajima iz zemlje, regiona, Evrope i svijeta, a koji se odnose na obrazovanje odraslih.

\section{Dostavljanje radova}

Radovi se dostavljaju Redakciji časopisa isključivo u elektronskoj formi na e-adresu: casopis@dvv-international.ba.

\section{Format teksta}

Tekstovi se dostavljaju u Word formatu u obimu od 30 redova normalnog proreda, a maksimalan broj strana teksta je 25 , izuzimajući prostor za navođenje korištene literature. Uz tekst je neophodno dostaviti i sažetak rada, u obimu do 18 redova, koji sadrži njegovu svrhu i bit. Na kraju sažetka potrebno je navesti 3-5 ključnih riječi, koje su stručno i naučno relevantne za prezentirani problem. Na kraju teksta navesti najvažnije podatke o autoru/ici (naučni stepen, poziciju na kojoj se nalazi, instituciju ili organizaciju u kojoj je zaposlen/a, kako je rad nastao). Ukoliko rad ima više autora, treba za svakog pojedinačno navesti sve navedene podatke.

\section{Jezik}

Radovi se dostavljaju na bosanskom, crnogorskom, engleskom, hrvatskom i srpskom jeziku i kao takvi se i objavljuju.

\section{Citiranje i literatura}

Sve reference teksta, bilješke ili popis korištene literature, treba da budu dati po savremenim metodološkim zahtjevima. Poziv na izvor u tekstu treba navesti naprimjer: (Gonnet, 1997) ili ako se radi o citatu (Filipović, 1987, 56). Ako su dva autora, treba navesti oba (Kulić, Despotović, 2001), a ukoliko ih je više, prezime prvog i saradnici (Delors i sar., 1998). Ove slučajeve ne treba navoditi u bilješkama. Bilješke se isključivo koriste za dopunu, pojašnjenje ili komentarisanje nečeg što je rečeno u tekstu.

Na kraju teksta navode se djela, koja su spomenuta u referencama i korištena literatura, abecednim redom prema prezimenima autora (knjige, zbornici, časopisi) naprimjer:

Adizes, Isak (1994), Upravljanje promjenama, Beograd, Privredni pregled.

Pastuović, N. (1991), Teorija kurikuluma u obrazovanju odraslih, Theleme, 1/1991, $15-27$.

Sve pristigle radove anonimno recenziraju dva recenzenta, koje imenuje Redakcija.

Adresa i kontakt-telefon Redakcije:

DVV International - Ured u Bosni i Hercegovini

Kulovića 8, 71000 Sarajevo

Tel.: +387 33 552-291, fax: + $\mathbf{3 8 7} 33$ 552-290 